Prepared in cooperation with the Colorado Department of Public Health and Environment

\title{
Use of Diverse Geochemical Data Sets to Determine Sources and Sinks of Nitrate and Methane in Groundwater, Garfield County, Colorado, 2009
}
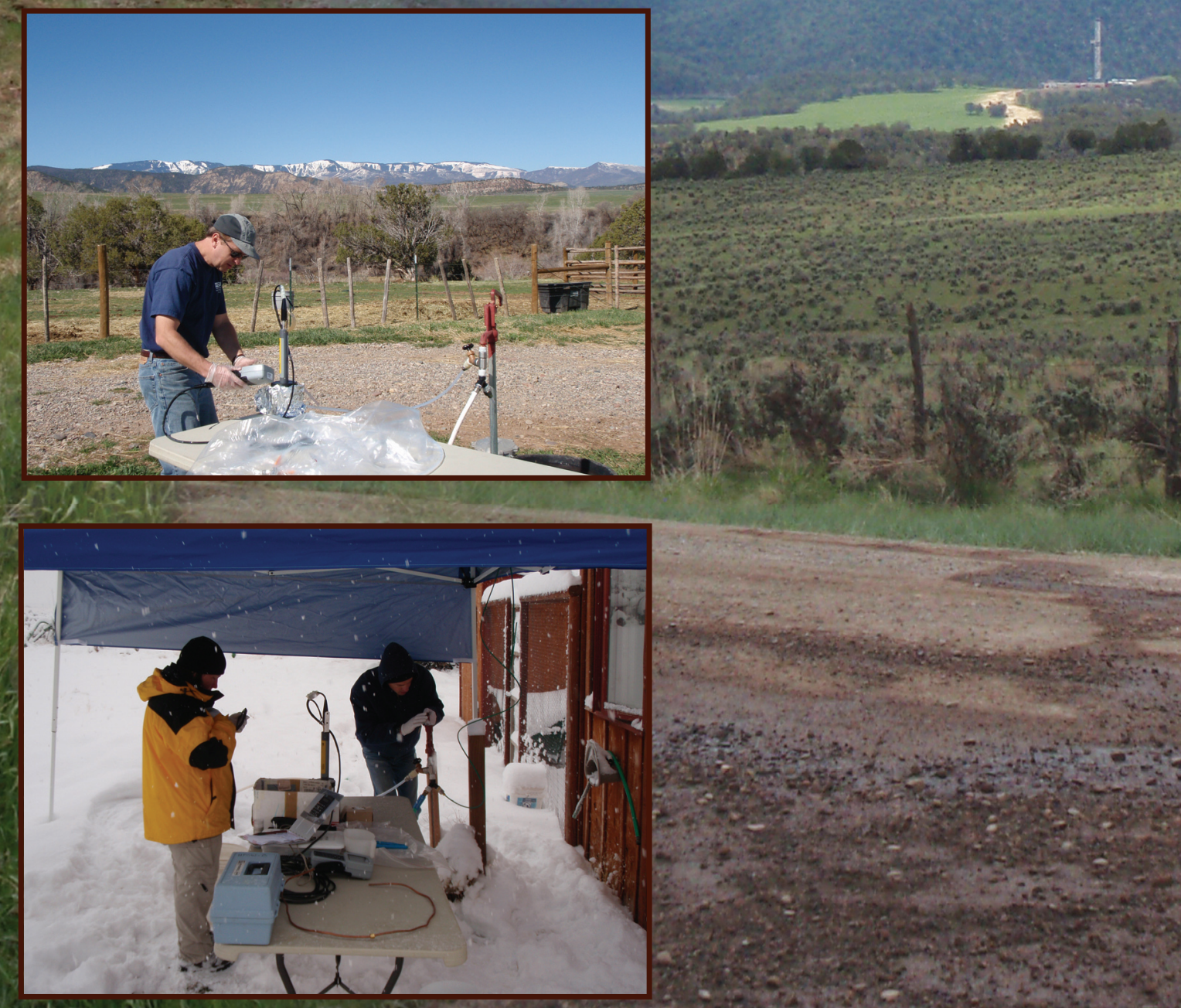

Scientific Investigations Report 2010-5215 


\section{COLLAGE (LEFT TO RIGHT)}

Horses near a domestic well, Garfield County, Colorado. Photograph by Peter McMahon, U.S. Geological Survey.

Livestock grazing in a pasture, Garfield County, Colorado. Photograph by Jim Collins, U.S. Geological Survey.

Drilling operation for a natural gas well, Garfield County, Colorado. Photograph by Jim Collins, U.S. Geological Survey.

\section{FRONT COVER}

\section{Top}

U.S. Geological Survey hydrologist measuring dissolved-oxygen concentrations in water from a domestic well, Garfield County, Colorado. Photograph by Peter McMahon, U.S. Geological Survey.

\section{Bottom}

U.S. Geological Survey hydrologists preparing to sample a domestic well, Garfield County, Colorado. Photograph by Jim Collins, U.S. Geological Survey. 


\section{Use of Diverse Geochemical Data Sets to Determine Sources and Sinks of Nitrate and Methane in Groundwater, Garfield County, Colorado, 2009}

By P.B. McMahon, J.C. Thomas, and A.G. Hunt

Prepared in cooperation with the Colorado Department of Public Health and Environment

Scientific Investigations Report 2010-5215 


\title{
U.S. Department of the Interior \\ KEN SALAZAR, Secretary \\ U.S. Geological Survey \\ Marcia K. McNutt, Director
}

\section{U.S. Geological Survey, Reston, Virginia: 2011}

\author{
For more information on the USGS — the Federal source for science about the Earth, its natural and living resources, \\ natural hazards, and the environment, visit http://www.usgs.gov or call 1-888-ASK-USGS \\ For an overview of USGS information products, including maps, imagery, and publications, \\ visit http://www.usgs.gov/pubprod \\ To order this and other USGS information products, visit http://store.usgs.gov
}

Any use of trade, product, or firm names is for descriptive purposes only and does not imply endorsement by the U.S. Government.

Although this report is in the public domain, permission must be secured from the individual copyright owners to reproduce any copyrighted materials contained within this report.

Suggested citation:

McMahon, P.B., Thomas, J.C., and Hunt, A.G., 2011, Use of diverse geochemical data sets to determine sources and sinks of nitrate and methane in groundwater, Garfield County, Colorado, 2009: U.S. Geological Survey Scientific Investigations Report 2010-5215, 40 p. 


\section{Contents}

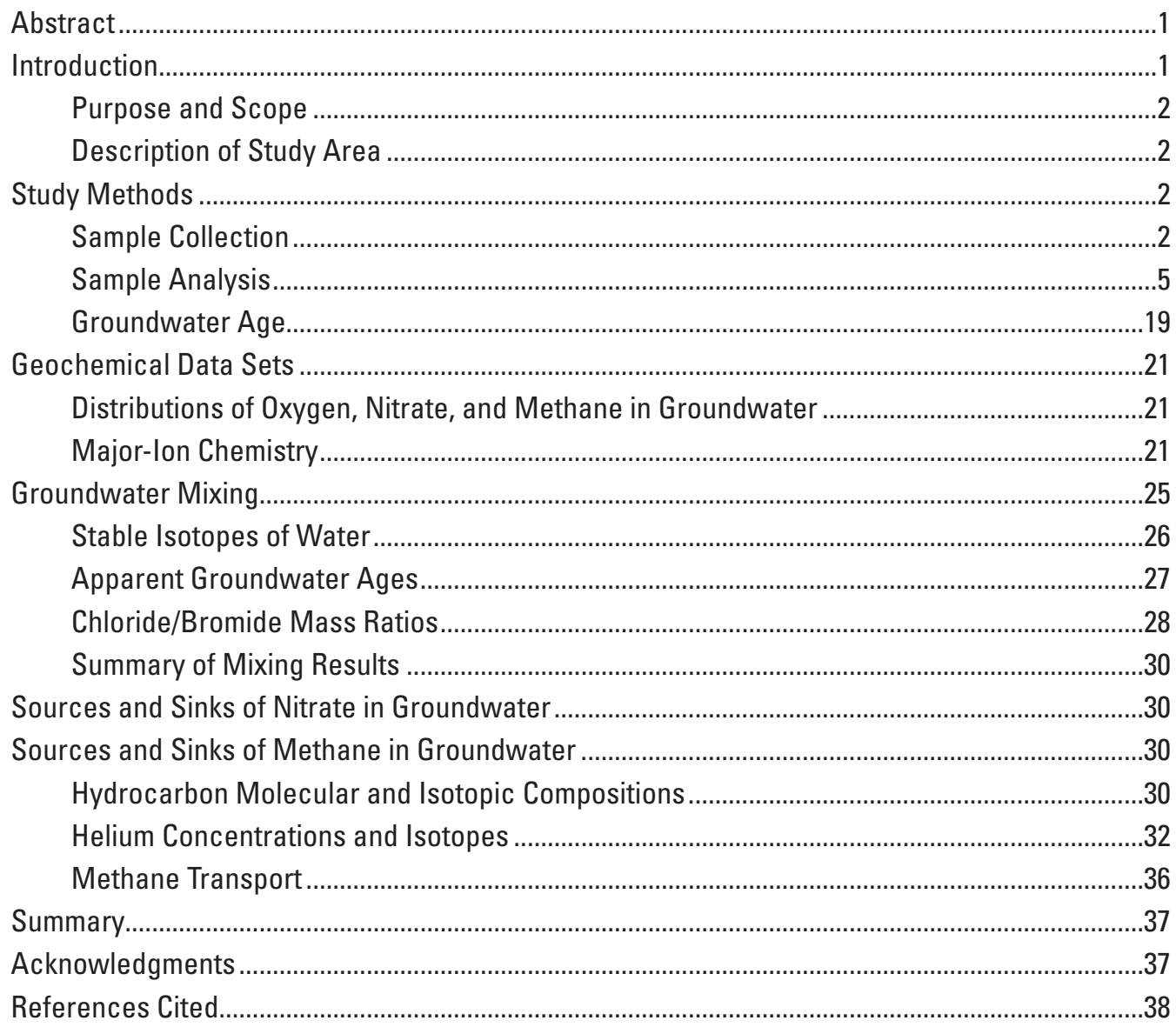

\section{Figures}

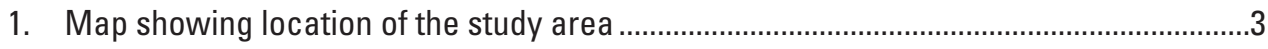

2. Map showing location of the domestic wells sampled for this study.............................. 4

3. Graph showing concentrations of chlorofluorocarbons and sulfur hexafluoride in North American air, and concentrations of tritium in precipitation at Salt Lake City, Utah, decayed to 2010

4-6. Maps showing:

4. Concentrations of dissolved oxygen in water from domestic wells sampled for this study.....

5. Concentrations of nitrate in water from domestic wells sampled for this study......... 23

6. Concentrations of methane in water from domestic wells sampled for this study.........24

7. Diagram showing major-ion chemistry of water from domestic wells sampled for this study, and major-ion chemistry of produced water from the Mesaverde Group ........25

8. Diagram showing major-ion chemistry of water from previously sampled domestic wells in the study area, and major-ion chemistry of produced water from the Mesaverde Group. 
9-14. Graphs showing:

9. Stable isotopic compositions of water from domesitic wells $(A)$ sampled for this study and $(B)$ sampled during previous studies.

10. Concentrations of tritium and chlorofluorocarbon-113 in water from domestic wells sampled for this study.

11. Apparent ages of the young fraction of water from domestic wells sampled for this study.

12. Chloride/bromide mass ratios in water from domestic wells sampled for this study and during previous studies

13. Measured concentrations of $(A)$ nitrate and $(B)$ methane in water from domestic wells sampled for this study, and $(C)$ concentrations of nitrate in the samples at the time they were recharged, in relation to concentrations of dissolved oxygen

14. Molecular and isotopic composition of short-chain hydrocarbons in water from domestic wells $(A)$ sampled for this study and $(B)$ sampled during previous studies.

15. Map showing concentrations of helium- 4 in water from domestic wells sampled for this study.

16. Graphs showing $(A)$ Methane concentrations in relation to helium- 4 concentrations in water from domestic wells sampled for this study and $(B)$ measured helium-3/ helium- 4 ratios corrected for excess air in relation to the relative amount of helium-4 derived from air-water equilibrium with respect to total helium- 4 in the sample, corrected for excess air

17. Graph showing concentrations of helium- 4 in water from domestic wells sampled for this study in relation to depth below the water table to the midpoint of the well screen....... 35

\section{Tables}

1. Chemical data for water collected from domestic wells in Garfield County, Colorado ...........6

2. Modeled helium-4 ages, in years, of water from well grflds9, Garfield County,

Colorado. 36

\section{Conversion Factors}

SI to Inch/Pound

\begin{tabular}{lll}
\hline Multiply & By & To obtain \\
\hline centimeter $(\mathrm{cm})$ & Length & \\
meter $(\mathrm{m})$ & 0.3937 & inch (in.) \\
kilometer $(\mathrm{km})$ & 3.281 & foot $(\mathrm{ft})$ \\
& 0.6214 & mile (mi) \\
\hline liter $(\mathrm{L})$ & Volume & \\
cubic centimeter $\left(\mathrm{cm}^{3}\right)$ & 0.2642 & gallon (gal) \\
\hline gram $(\mathrm{g})$ & 0.06102 & cubic inch (in $\left.{ }^{3}\right)$ \\
\hline
\end{tabular}

Temperature in degrees Celsius $\left({ }^{\circ} \mathrm{C}\right)$ may be converted to degrees Fahrenheit $\left({ }^{\circ} \mathrm{F}\right)$ as follows:

$$
{ }^{\circ} \mathrm{F}=\left(1.8 \times{ }^{\circ} \mathrm{C}\right)+32
$$

Vertical coordinate information is referenced to the North American Vertical Datum of 1988 (NAVD 88).

Horizontal coordinate information is referenced to the North American Datum of 1983 (NAD 83).

Elevation, as used in this report, refers to distance above the vertical datum. 


\section{Abbreviations and Acronyms}

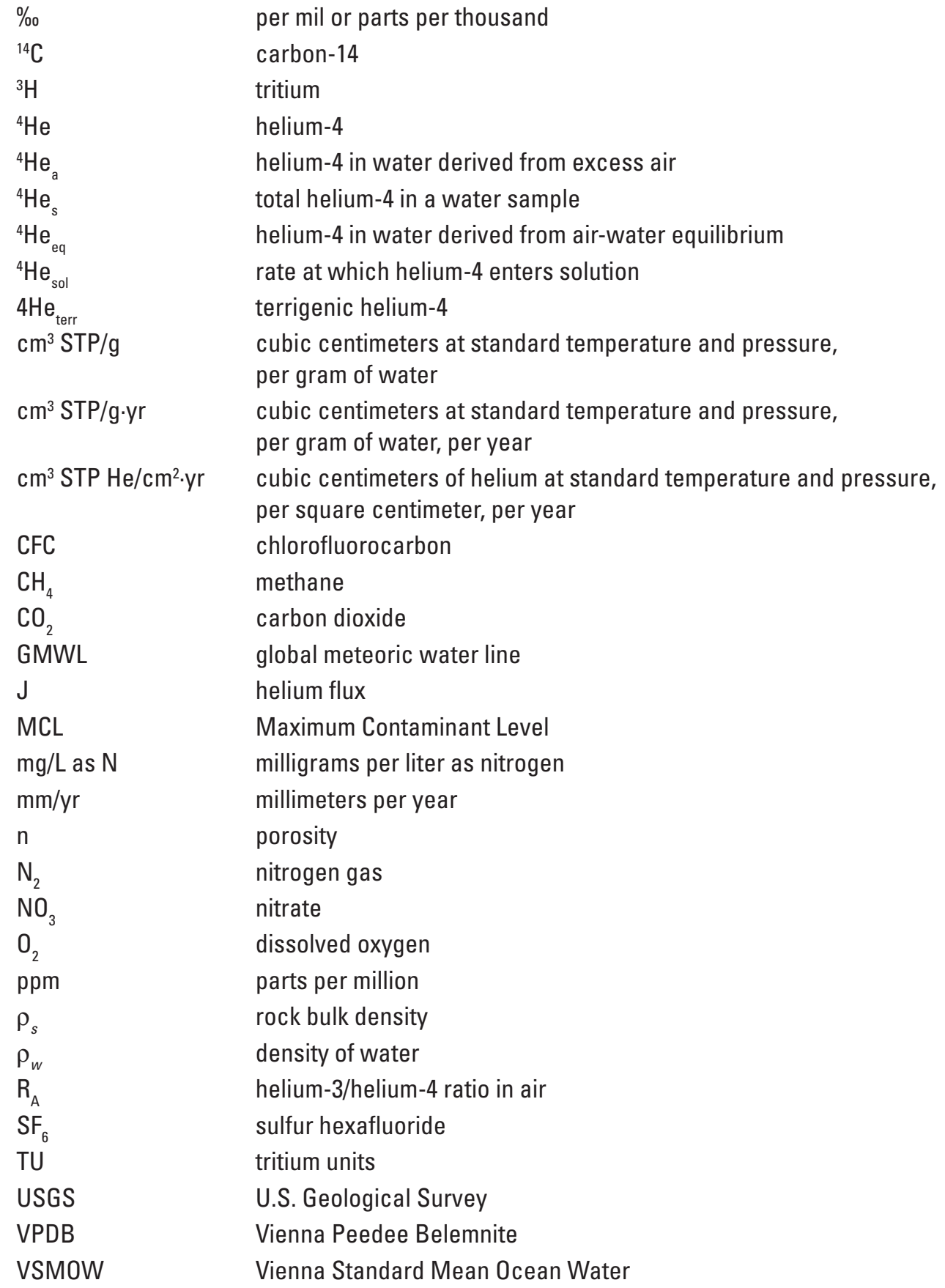

$\%$

${ }^{14} \mathrm{C}$

${ }^{3} \mathrm{H}$

${ }^{4} \mathrm{He}$

${ }^{4} \mathrm{He}_{\mathrm{a}}$

${ }^{4} \mathrm{He}_{\mathrm{s}}$

${ }^{4} \mathrm{He}_{\text {eq }}$

${ }^{4} \mathrm{He}_{\text {sol }}$

$4 \mathrm{He}_{\text {terr }}$

$\mathrm{cm}^{3} \mathrm{STP} / \mathrm{g}$

$\mathrm{cm}^{3} \mathrm{STP} / \mathrm{g} \cdot \mathrm{yr}$

$\mathrm{cm}^{3} \mathrm{STP} \mathrm{He} / \mathrm{cm}^{2} \cdot \mathrm{yr}$

CFC

$\mathrm{CH}_{4}$

$\mathrm{CO}_{2}$

GMWL

$\mathrm{J}$

MCL

$\mathrm{mg} / \mathrm{L}$ as N

$\mathrm{mm} / \mathrm{yr}$

$n$

$\mathrm{N}_{2}$

$\mathrm{NO}_{3}$

$\mathrm{O}_{2}$

ppm

$\rho_{s}$

$\rho_{w}$

$\mathrm{R}_{\mathrm{A}}$

$\mathrm{SF}_{6}$

TU

USGS

VPDB

VSMOW

per mil or parts per thousand

carbon-14

tritium

helium-4

helium-4 in water derived from excess air

total helium-4 in a water sample

helium-4 in water derived from air-water equilibrium

rate at which helium-4 enters solution

terrigenic helium-4

cubic centimeters at standard temperature and pressure,

per gram of water

cubic centimeters at standard temperature and pressure,

per gram of water, per year

cubic centimeters of helium at standard temperature and pressure,

per square centimeter, per year

chlorofluorocarbon

methane

carbon dioxide

global meteoric water line

helium flux

Maximum Contaminant Level

milligrams per liter as nitrogen

millimeters per year

porosity

nitrogen gas

nitrate

dissolved oxygen

parts per million

rock bulk density

density of water

helium-3/helium-4 ratio in air

sulfur hexafluoride

tritium units

U.S. Geological Survey

Vienna Peedee Belemnite

Vienna Standard Mean Ocean Water 



\title{
Use of Diverse Geochemical Data Sets to Determine Sources and Sinks of Nitrate and Methane in Groundwater, Garfield County, Colorado, 2009
}

\author{
By P.B. McMahon, J.C. Thomas, and A.G. Hunt
}

\section{Abstract}

Previous water-quality assessments reported elevated concentrations of nitrate and methane in water from domestic wells screened in shallow zones of the Wasatch Formation, Garfield County, Colorado. In 2009, the U.S. Geological Survey, in cooperation with the Colorado Department of Public Health and Environment, analyzed samples collected from 26 domestic wells for a diverse set of geochemical tracers for the purpose of determining sources and sinks of nitrate and methane in groundwater from the Wasatch Formation.

Nitrate concentrations ranged from less than 0.04 to 6.74 milligrams per liter as nitrogen $(\mathrm{mg} / \mathrm{L}$ as $\mathrm{N})$ and were significantly lower in water samples with dissolved-oxygen concentrations less than $0.5 \mathrm{mg} / \mathrm{L}$ than in samples with dissolved-oxygen concentrations greater than or equal to $0.5 \mathrm{mg} / \mathrm{L}$. Chloride/bromide mass ratios and tracers of groundwater age (tritium, chlorofluorocarbons, and sulfur hexafluoride) indicate that septic-system effluent or animal waste was a source of nitrate in some young groundwater (less than 50 years), although other sources such as fertilizer also may have contributed nitrate to the groundwater. Nitrate and nitrogen gas $\left(\mathrm{N}_{2}\right)$ concentrations indicate that denitrification was the primary sink for nitrate in anoxic groundwater, removing 99 percent of the original nitrate content in some samples that had nitrate concentrations greater than $10 \mathrm{mg} / \mathrm{L}$ as $\mathrm{N}$ at the time of recharge.

Methane concentrations ranged from less than 0.0005 to $32.5 \mathrm{mg} / \mathrm{L}$ and were significantly higher in water samples with dissolved-oxygen concentrations less than $0.5 \mathrm{mg} / \mathrm{L}$ than in samples with dissolved-oxygen concentrations greater than or equal to $0.5 \mathrm{mg} / \mathrm{L}$. High methane concentrations (greater than $1 \mathrm{mg} / \mathrm{L}$ ) in some samples were biogenic in origin and appeared to be derived from a relatively deep source on the basis of helium concentrations and isotopic data. One such sample had water-isotopic and major-ion compositions similar to that of produced water from the underlying Mesaverde Group, which was the primary natural-gas producing interval in the study area. Methane in the Mesaverde Group was largely thermogenic in origin so biogenic methane in the sample probably was derived from deeper zones in the Wasatch Formation. The primary methane sink in the aquifer appeared to be methane oxidation on the basis of dissolved-oxygen and methane concentrations and methane isotopic data.

The diverse data sets used in this study enhance previous water-quality assessments by providing new and more complete insights into the sources and sinks of nitrate and methane in groundwater. Field measurements of dissolved oxygen in groundwater were useful indicators of the Wasatch Formation's vulnerability to nitrate and methane contamination or enrichment. Results from this study also provide new evidence for the movement of water, ions, and gases into the shallow Wasatch Formation from sources such as the Mesaverde Group and deeper Wasatch Formation.

\section{Introduction}

Nitrate, methane, and a few other chemical constituents were detected in relatively high concentrations in water from domestic wells screened in shallow zones of the Wasatch Formation, Garfield County, Colorado during previous waterquality assessments (URS Corporation, 2006; Papadopulos \& Associates, Inc., 2008). In 2009, the U.S. Geological Survey, in cooperation with the Colorado Department of Public Health and Environment, analyzed samples collected from 26 domestic wells for a diverse set of geochemical tracers for the purpose of determining sources and sinks of nitrate and methane in groundwater from the Wasatch Formation. Interpretations regarding possible sources and sinks of those constituents are important because they could help water managers understand why and where groundwater is vulnerable to certain types of contamination. Interpretations based on a relatively limited set of chemical indicators or tracers could have large uncertainties if the sources and sinks of chemicals in groundwater are complex, or if the chemical tracers on which interpretations are based have been altered by subsurface processes. Other environmental tracers that could be helpful in these circumstances include reduction/oxidation (redox) constituents (Chapelle 
and others, 1995; McMahon and Chapelle, 2008), stable isotopes of water (Böhlke and others, 2007; Landon and others, 2008), tracers of groundwater age (Manning and others, 2005; Rupert and Plummer, 2009), and dissolved noble gases (Zhou and others, 2005; Sherwood Lollar and Ballentine, 2009).

Each of those tracers measures different processes and when used in combination, the diverse data sets can sometimes provide new and more complete insights into the sources and sinks of chemical constituents in groundwater.

\section{Purpose and Scope}

The purpose of this report was to determine sources and sinks of nitrate and methane in groundwater from the Wasatch Formation in Garfield County, Colorado, by use of diverse data sets that included concentrations of major ions, nutrients, redox constituents, and noble gases, hydrocarbon molecular and isotopic compositions, water isotopic compositions, and tracers of groundwater age. The study area is located between Silt and Rifle, Colorado (fig. 1). Twenty-six domestic wells were sampled for this broad suite of chemical and isotopic tracers (fig. 2). Ten wells were located north of the Colorado River and sampled in April 2009. Sixteen wells were located south of the river and sampled in April and October 2009.

\section{Description of Study Area}

The study area is located between Silt and Rifle, Colorado (fig. 1). The mean annual air temperature in Rifle, Colorado, was $8.7^{\circ} \mathrm{C}$ for the period 1910 to 2007 , and mean annual precipitation was $29.4 \mathrm{~cm}$ (High Plains Regional Climate Center, 2010). The elevation of sampling locations ranged from 1,672 to $2,155 \mathrm{~m}$. Mean annual precipitation and air temperatures at the highest-elevation sites are likely to be wetter and colder than sampling sites at lower elevations.

The primary geologic units of interest in the study were the Williams Fork and Wasatch Formations. The Williams Fork Formation, part of the Mesaverde Group, consists of mostly fluvial sedimentary rock of Late Cretaceous age (Johnson and Rice, 1990). Most natural gas wells in the study area were completed in the Williams Fork Formation at depths of about 1,830 to $3,050 \mathrm{~m}$ below ground surface (URS Corporation, 2006), but deeper sandstones in the Mesaverde Group and pre-Cretaceous sedimentary rock below the Mesaverde Group also produce gas (Johnson and Rice, 1990). The Wasatch Formation is the primary bedrock unit at land surface in the study area. The Wasatch Formation consists of mostly fluvial sedimentary rock of Tertiary age (Paleocene and Eocene) (Donnell, 1969). Most domestic wells in the study area were screened in the Wasatch Formation at depths generally less than $185 \mathrm{~m}$ below land surface. The thickness of the Wasatch Formation ranges from about 365 m near the southern end of the Divide Creek anticline to more than $1,710 \mathrm{~m}$ along the west side of the study area (URS Corporation, 2006). The Divide Creek anticline, located in the southeastern part of the study area, plunges into the central part of the study area (Hoak and Klawitter, 1977; Grout and Verbeek, 1992; URS Corporation, 2006). Structural features (for example, faults and fractures) associated with the anticline may be important pathways for water or gas movement, or both, from deeper to shallower zones in the area (URS Corporation, 2006).

Static water levels in the Wasatch Formation reported in drillers' logs ranged from about 0 to $105 \mathrm{~m}$ below land surface, with a mean of $22 \mathrm{~m}$ (URS Corporation, 2006). The primary sources of recharge to the Wasatch Formation were precipitation in upland areas and irrigation at lower elevations. In general, groundwater flow in the study area is probably topography controlled, moving from upland areas to local streams and springs. The Colorado River is interpreted as the regional discharge area for groundwater in the Wasatch Formation (URS Corporation, 2006).

More detailed descriptions of the geology and hydrology, as well as the natural gas production history of the study area, can be found in Johnson and Rice (1990), Shroba and Scott (1997, 2001), URS Corporation (2006), and Papadopulos \& Associates, Inc. (2008).

\section{Study Methods}

Water samples were collected from 26 domestic wells in April and October 2009. Wells were selected to provide relatively broad spatial coverage of the aquifer north and south of the Colorado River. Sixteen wells were located south of the river and 10 wells were located north of the river (fig. 2). Several criteria had to be met before a well was selected for sampling. The criteria included (1) well owner permission to sample, (2) availability of information on well depth, top and bottom of screened interval, and depth to water at time of drilling, (3) availability of information showing geology of the screened interval, and (4) availability of a sampling point on the well upstream from any pressure tank or treatment device.

\section{Sample Collection}

Water samples were collected from the well discharge after readings of specific conductance, $\mathrm{pH}$, temperature, turbidity, and dissolved-oxygen concentration had become stable (as defined by Koterba and others, 1995). Three general groups of samples were collected: (1) inorganic ions, (2) stable isotopes and dissolved gases, and (3) environmental tracers of groundwater age. Processing chambers were used during the collection and preservation of samples to reduce airborne contamination in the samples. 


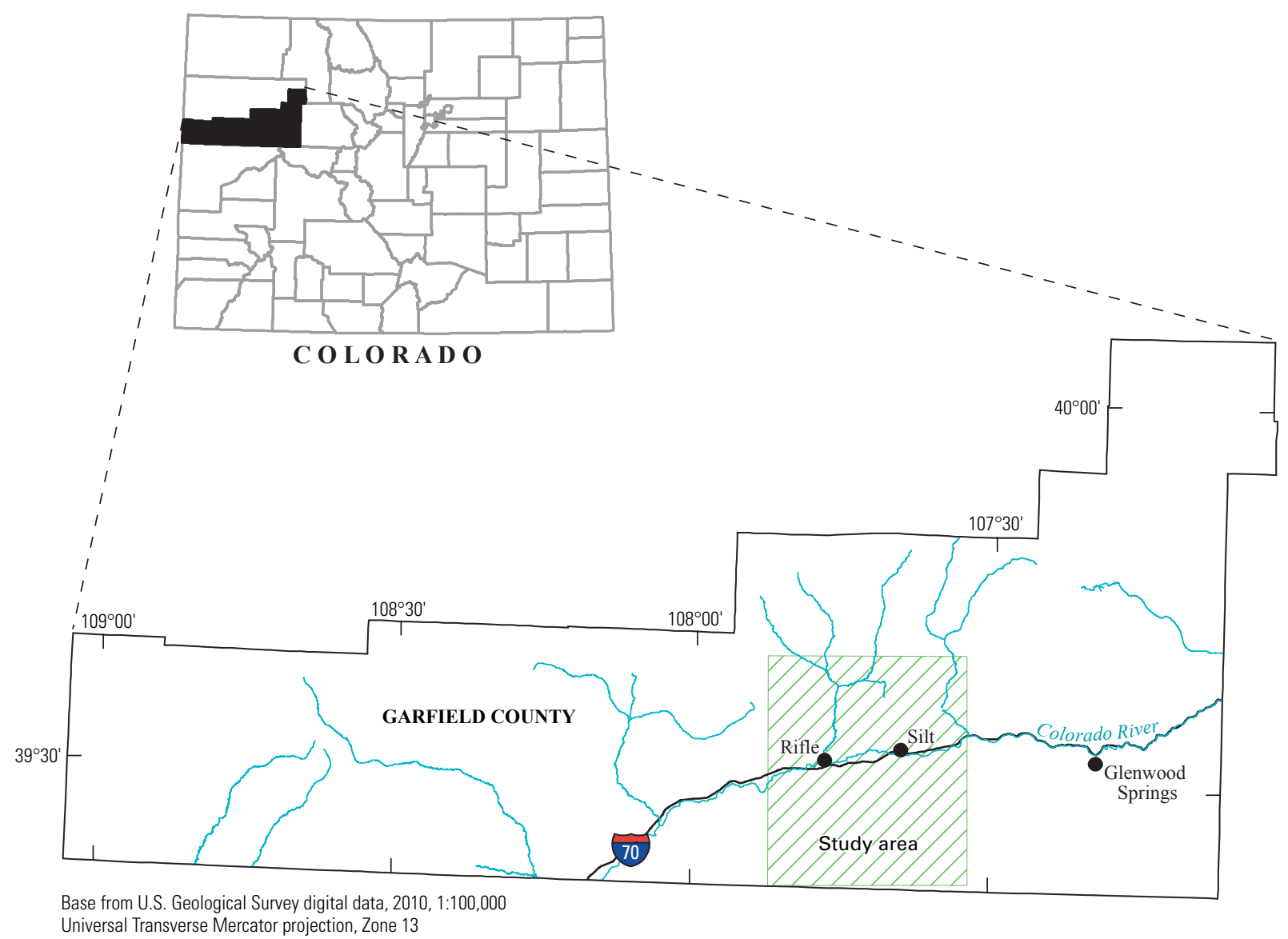
Universal Transverse Mercator projection, Zone 13

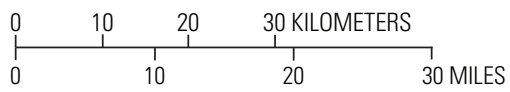

Figure 1. Location of the study area.

Inorganic ions.-Samples for the analysis of alkalinity, major ions, and nutrients were filtered ( 0.45 micron) in the field and stored in precleaned plastic bottles. Cation samples were acidified in the field to $\mathrm{pH}$ less than 2 using nitric acid. Nutrient samples were kept chilled on ice until delivered to the laboratory.

Stable isotopes and dissolved gases.-Water-isotope samples $\left(\delta^{18} \mathrm{O}\left[\mathrm{H}_{2} \mathrm{O}\right]\right.$ and $\left.\delta^{2} \mathrm{H}\left[\mathrm{H}_{2} \mathrm{O}\right]\right)$ were unfiltered and collected in precleaned glass bottles with polyseal caps that were secured with tape. Samples for analysis of the major gases methane, nitrogen $\left(\mathrm{N}_{2}\right)$, argon, and carbon dioxide were unfiltered and collected in precleaned glass bottles that were filled and capped with thick rubber stoppers under water to exclude headspace (atmospheric contamination). Major-gas samples were collected in duplicate at each site. Samples for analysis of the hydrocarbon gases methane, ethane, and propane and the isotopic composition of methane $\left(\delta^{13} \mathrm{C}_{\left[\mathrm{CH}_{4}\right]}\right.$ and $\left.\delta^{2} \mathrm{H}\left[\mathrm{CH}_{4}\right]\right)$ were unfiltered and collected in precleaned plastic bottles that were filled and capped under water. The samples were preserved in the field with a bactericide and kept chilled on ice until delivered to the laboratory. In April, unfiltered noble-gas samples were collected in precleaned glass bottles that were filled and capped with thick rubber stoppers under water to exclude headspace. These samples were analyzed for helium and neon and were used to identify helium-enriched waters that could not be age dated using the tritium/helium-3 method (Ludin and others, 1998). Wells with the greatest helium enrichment were resampled in October for analysis of the full suite of noble gases (helium, neon, argon, krypton, xenon). The October samples were unfiltered and collected in copper tubes that were sealed on both ends with pinch clamps. The copper tubes were connected in line with the pumpdischarge line to prevent atmospheric contamination and slight backpressure was applied to the tubes while filling to help keep the noble gases in solution.

Environmental tracers of groundwater age.-Tritium samples were unfiltered and collected in precleaned plastic bottles with polyseal caps that were secured with tape. Samples for analysis of chlorofluorocarbon-11, chlorofluorocarbon-12, and chlorofluorocarbon-113 were unfiltered and collected in precleaned glass bottles that were filled and capped under water to exclude headspace. The caps were secured with tape and the bottles were kept chilled on ice until delivered to the 


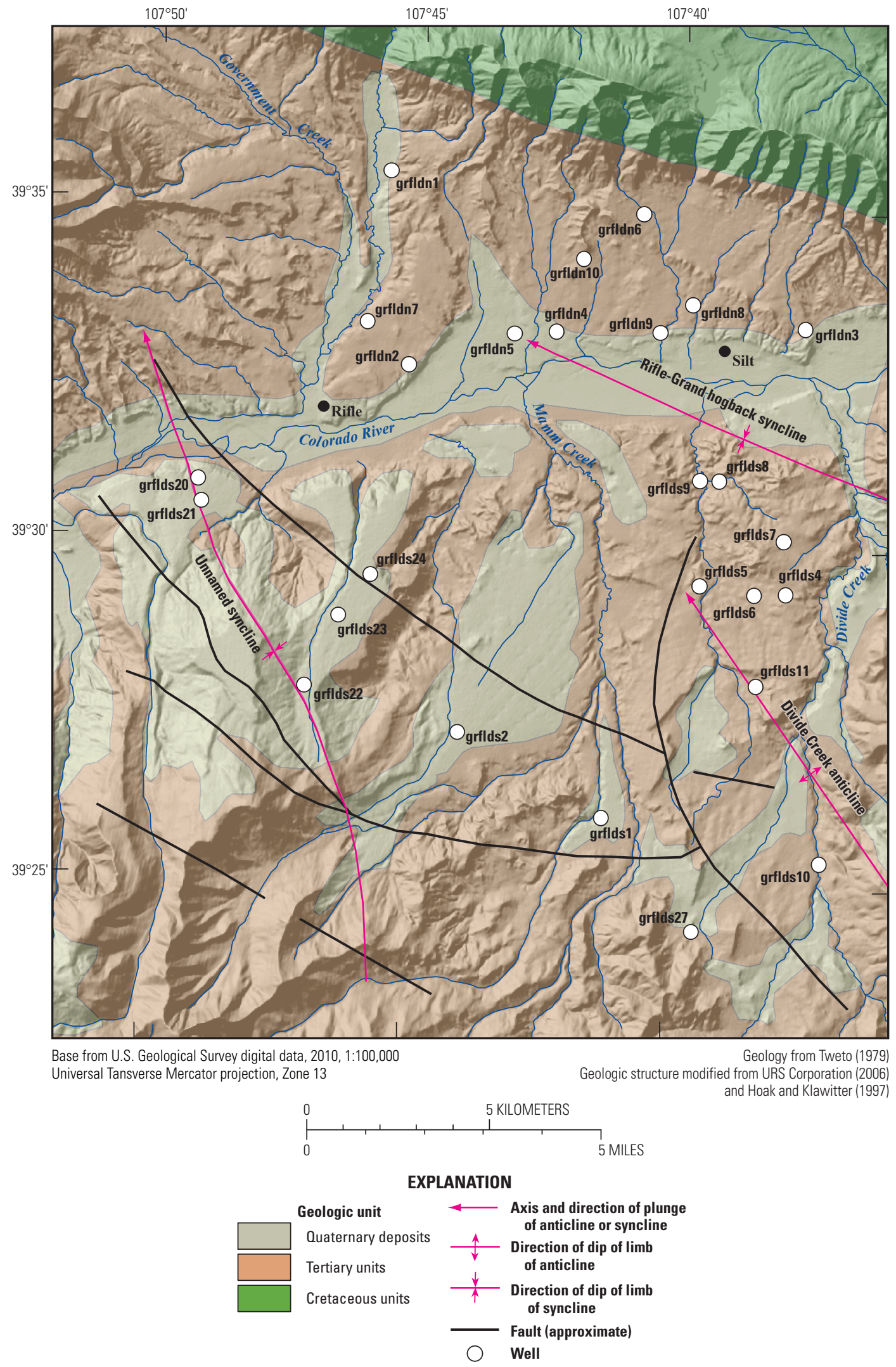

Figure 2. Location of the domestic wells sampled for this study. 
laboratory. Sulfur hexafluoride samples were collected and preserved in the same way as chlorofluorocarbon samples. Samples for tritium/helium-3 dating were collected in copper tubes as described above.

\section{Sample Analysis}

Inorganic ions.-Alkalinity was measured in the field by incremental titration using 0.16 normal sulfuric acid. Major ions and nutrients were measured by standard methods of the U.S. Geological Survey (USGS) National Water Quality Laboratory in Lakewood, Colorado (Fishman and Friedman, 1989), with a reproducibility of about \pm 1 percent.

Stable isotopes and dissolved gases.-The water-isotope samples were analyzed at the USGS Stable Isotope Laboratory in Reston, Virginia, by hydrogen- and carbon dioxide-gas equilibration and mass spectrometry (U.S. Geological Survey, 2008a). Stable-isotope results are reported using the standard delta $(\delta)$ notation, in per mil (\%, parts per thousand). For example, the stable oxygen-isotopic composition of a water sample $\left(\delta^{18} \mathrm{O}\left[\mathrm{H}_{2} \mathrm{O}\right]_{\text {sample }}\right)$ is equal to

$$
\delta^{18} \mathrm{O}\left[\mathrm{H}_{2} \mathrm{O}\right]_{\text {sample }}=\left(\left({ }^{18} \mathrm{O} /{ }^{16} \mathrm{O}\right)_{\text {sample }} /\left({ }^{18} \mathrm{O} /{ }^{16} \mathrm{O}\right)_{\text {ref }}-1\right) \cdot 1000
$$

where

${ }^{18} \mathrm{O} /{ }^{16} \mathrm{O}$ is the ratio of the oxygen- 18 to oxygen- 16 isotopes in the sample and a reference (ref) material.

The $\delta^{2} \mathrm{H}\left[\mathrm{H}_{2} \mathrm{O}\right]$ and $\delta^{18} \mathrm{O}\left[\mathrm{H}_{2} \mathrm{O}\right]$ values were referenced to the VSMOW scale (Vienna Standard Mean Ocean Water) (Coplen, 1988), with reproducibility of about $\pm 1 \%$ and $\pm 0.1 \%$, respectively. Major gases were measured at the USGS Chlorofluorocarbon Laboratory in Reston, Virginia (U.S. Geological Survey, 2008b), by gas chromatography with reproducibility of about \pm 2 to 4 percent. Major gases were measured in duplicate and average values were reported in table 1. Hydrocarbon molecular and isotopic compositions were measured at the Isotech Laboratory, Champaign, Illinois, by gas chromatography and mass spectrometry, respectively. Concentrations of methane, ethane, and propane were reported in mole percent with a reproducibility of about \pm 2 percent. The $\left.\delta^{13} \mathrm{C}_{\left[\mathrm{CH}_{4}\right]}\right]$ values were reported relative to Vienna Peedee Belemnite (VPDB) with a reproducibility of $\pm 0.3 \%$. The $\delta^{2} \mathrm{H}\left[\mathrm{CH}_{4}\right]$ values were reported relative to VSMOW with a reproducibility of $\pm 2 \%$. Noble-gas samples (helium and neon) collected in April were analyzed at the USGS Chlorofluorocarbon Laboratory in Reston, Virginia (U.S. Geological Survey, 2008b), using gas chromatography, with a reproducibility of about \pm 10 to 20 percent. Noble-gas samples collected in October were analyzed at the USGS Noble Gas Laboratory in Denver, Colorado (Hunt and others, 2010), using mass spectrometry. Reproducibilities for helium, neon, argon, krypton, and xenon were about $\pm 1,3,2,3$, and 3 percent, respectively.
Environmental tracers of groundwater age.-Tritium was analyzed at the USGS Tritium Laboratory in Menlo Park, California, using electrolytic enrichment and gas counting (Thatcher and others, 1977). Reproducibility of the tritium analyses generally was better than \pm 5 percent. Chlorofluorocarbons and sulfur hexafluoride were analyzed at the USGS Chlorofluorocarbon Laboratory in Reston, Virginia, using gas chromatography (Plummer and Busenberg, 2000; Busenberg and Plummer, 2000). The reproducibility of chlorofluorocarbon and sulfur hexafluoride measurements was about \pm 3 percent. Samples for tritium/helium-3 dating were analyzed at the Lamont-Doherty Earth Observatory Noble Gas Laboratory in Palisades, New York (Schlosser and others, 1989; Ludin and others, 1998). These samples were analyzed for helium-4, neon, and helium-3/helium-4 ratios using mass spectrometry, with reproducibilities of about $\pm 1,3$, and 1 percent, respectively.

Determination of recharge temperature, excess air, excess nitrogen gas, and initial nitrate concentration in recharge.--Recharge temperature refers to the temperature of water at the time it recharged the aquifer and excess air refers to air bubbles that get trapped in groundwater at the time of recharge (Andrews and Lee, 1979; Heaton and Vogel, 1981). Recharge temperatures and concentrations of excess air were calculated using measured concentrations of nitrogen gas and argon (Herzberg and Mazor, 1979; Heaton and Vogel, 1981; Böhlke and others, 2002). In the calculations, recharge elevation was assumed to be the elevation of the water table in the sampled well and salinity was assumed to equal the concentration of dissolved solids in the sample (table 1). Generally, this method for determining recharge temperature and excess air is suitable for samples containing more than $2 \mathrm{mg} / \mathrm{L}$ dissolved oxygen because they are not likely to contain excess nitrogen gas from denitrification. In other words, the only source of nitrogen gas in those samples would be the atmosphere. Excess nitrogen gas from denitrification is more likely to occur in groundwater containing less than $2 \mathrm{mg} / \mathrm{L}$ dissolved oxygen because denitrification is a microbial process that occurs in the absence of dissolved oxygen. McMahon and Chapelle (2008) proposed a dissolved-oxygen concentration threshold of $0.5 \mathrm{mg} / \mathrm{L}$ for the onset of denitrification in groundwater, but because of mixing between oxic and anoxic waters in some well screens, the effects of denitrification sometimes can be observed in samples containing more than $0.5 \mathrm{mg} / \mathrm{L}$ dissolved oxygen (Böhlke and others, 2002, 2007; McMahon and others, 2004). In this study, for samples with dissolved-oxygen concentrations less than or equal to $2 \mathrm{mg} / \mathrm{L}$, it was assumed that recharge temperatures and concentrations of excess air were equal to the median recharge temperature and excess-air concentration in samples with dissolved-oxygen concentrations greater than $2 \mathrm{mg} / \mathrm{L}\left(7.9^{\circ} \mathrm{C}\right.$ and 1.9 cubic centimeters at standard temperature and pressure, per liter of water $\left(\mathrm{cm}^{3} \mathrm{STP} / \mathrm{L}\right)$, respectively). 
Table 1. Chemical data for water collected from domestic wells in Garfield County, Colorado.

[NGVD29, North American Vertical Datum of 1929; m, meters; ${ }^{\circ} \mathrm{C}$, degrees Celsius; $\mu \mathrm{S} / \mathrm{cm}$, microsiemens per centimeter; $\mathrm{mg} / \mathrm{L}$, milligrams per liter; $\mathrm{CaCO}_{3}$, calcium carbonate; NTU, nephelometric turbidity units; <, less than; --, no data; E, estimated ${ }^{1} ; \mathrm{N}$, nitrogen; P, phosphorus; $\mu \mathrm{g} / \mathrm{L}$, micrograms per liter; \%, per mil; VSMOW, Vienna Standard Mean Ocean Water; TU, tritium units; VPDB, Vienna PeeDee Belemnite; mol \%, mole percent; $\mathrm{cm}^{3}$ STP/g, cubic centimeters at standard temperature and pressure, per gram of water; $\mathrm{R} / \mathrm{R}_{\mathrm{a}}$, helium-3/helium- 4 ratio in the sample divided by the helium-3/helium- 4 ratio in air; $\mathrm{cm}^{3} \mathrm{STP} / \mathrm{L}$, cubic centimeters at standard temperature and pressure, per liter of water; g, gram; fmol/L, femtomole per liter; pptv, parts per trillion by volume; $\mathrm{pg} / \mathrm{kg}$, picogram per kilogram]

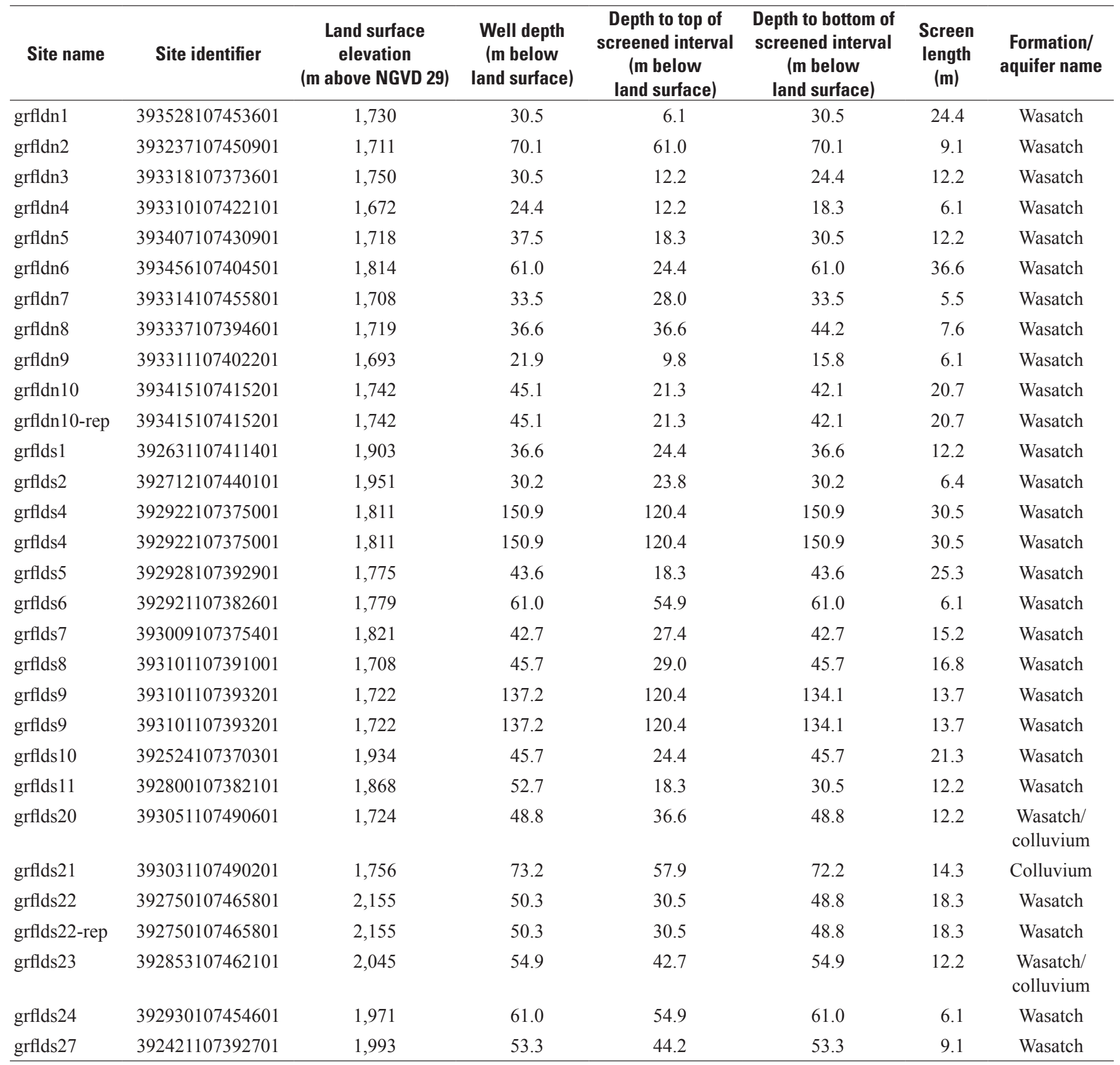

${ }^{1}$ Estimated (E) concentrations are those concentrations that are greater than or equal to the long-term method detection limit but less than the laboratory reporting level or lowest calibration standard, whichever is greater (Childress and others, 1999). 
Table 1. Chemical data for water collected from domestic wells in Garfield County, Colorado.—Continued

[NGVD29, North American Vertical Datum of $1929 ; \mathrm{m}$, meters; ${ }^{\circ} \mathrm{C}$, degrees Celsius; $\mu \mathrm{S} / \mathrm{cm}$, microsiemens per centimeter; mg/L, milligrams per liter; $\mathrm{CaCO}_{3}$, calcium carbonate; NTU, nephelometric turbidity units; <, less than; --, no data; E, estimated ${ }^{1} ; \mathrm{N}$, nitrogen; $\mathrm{P}$, phosphorus; $\mu \mathrm{g} / \mathrm{L}$, micrograms per liter; \%o, per mil; VSMOW, Vienna Standard Mean Ocean Water; TU, tritium units; VPDB, Vienna PeeDee Belemnite; mol \%, mole percent; $\mathrm{cm}^{3}$ STP/g, cubic centimeters at standard temperature and pressure, per gram of water; $\mathrm{R} / \mathrm{R}_{\mathrm{a}}$, helium-3/helium- 4 ratio in the sample divided by the helium-3/helium- 4 ratio in air; $\mathrm{cm}^{3} \mathrm{STP} / \mathrm{L}$, cubic centimeters at standard temperature and pressure, per liter of water; g, gram; fmol/L, femtomole per liter; pptv, parts per trillion by volume; $\mathrm{pg} / \mathrm{kg}$, picogram per kilogram]

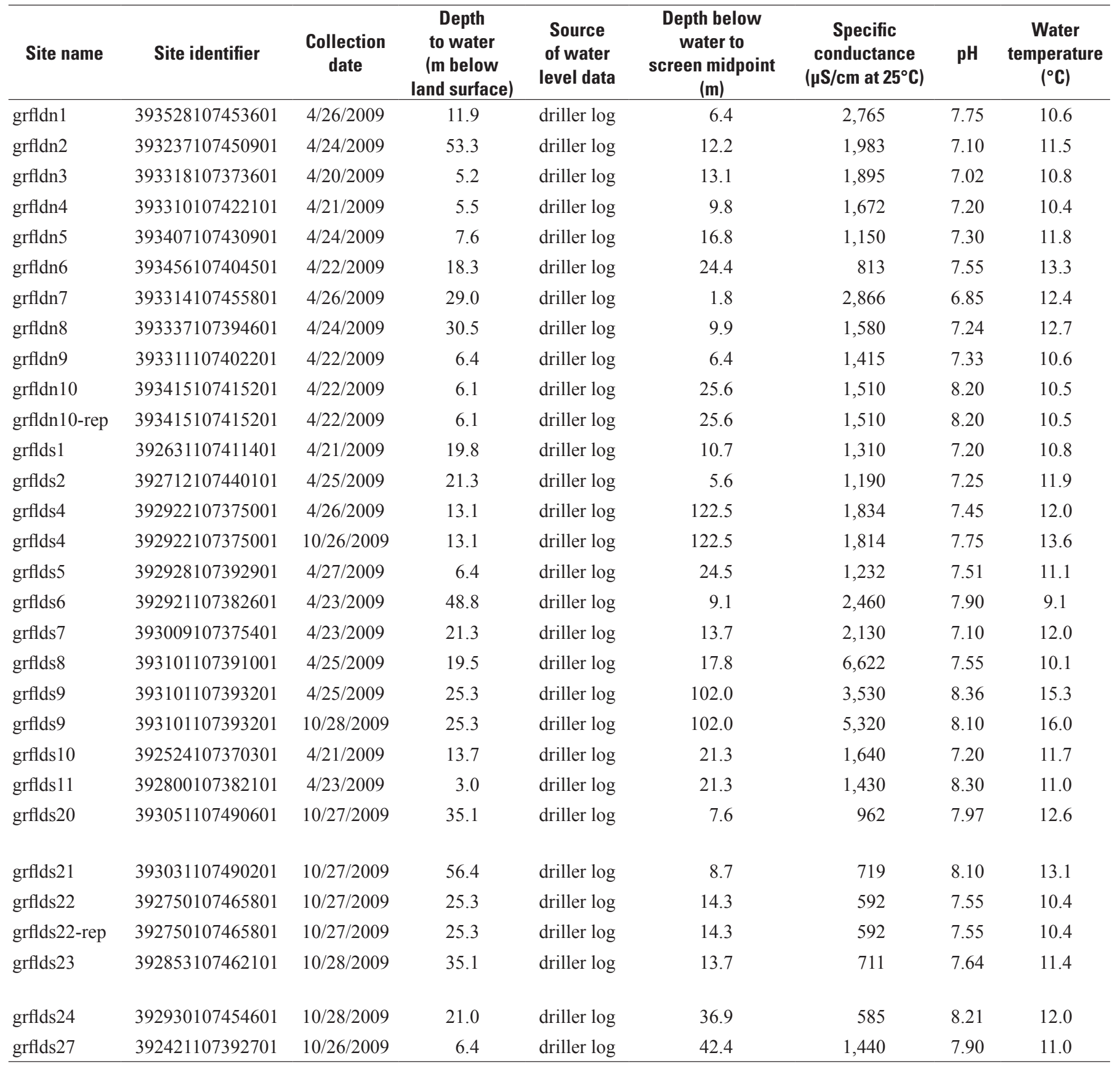

${ }^{1}$ Estimated (E) concentrations are those concentrations that are greater than or equal to the long-term method detection limit but less than the laboratory reporting level or lowest calibration standard, whichever is greater (Childress and others, 1999). 
Table 1. Chemical data for water collected from domestic wells in Garfield County, Colorado._-Continued

[NGVD29, North American Vertical Datum of 1929; m, meters; ${ }^{\circ} \mathrm{C}$, degrees Celsius; $\mu \mathrm{S} / \mathrm{cm}$, microsiemens per centimeter; $\mathrm{mg} / \mathrm{L}$, milligrams per liter; $\mathrm{CaCO}_{3}$, calcium carbonate; NTU, nephelometric turbidity units; <, less than; --, no data; E, estimated ${ }^{1} ; \mathrm{N}$, nitrogen; P, phosphorus; $\mu \mathrm{g} / \mathrm{L}$, micrograms per liter; \%, per mil; VSMOW, Vienna Standard Mean Ocean Water; TU, tritium units; VPDB, Vienna PeeDee Belemnite; mol \%, mole percent; $\mathrm{cm}^{3}$ STP/g, cubic centimeters at standard temperature and pressure, per gram of water; $\mathrm{R} / \mathrm{R}_{\mathrm{a}}$, helium-3/helium- 4 ratio in the sample divided by the helium-3/helium- 4 ratio in air; $\mathrm{cm}^{3} \mathrm{STP} / \mathrm{L}$, cubic centimeters at standard temperature and pressure, per liter of water; g, gram; fmol/L, femtomole per liter; pptv, parts per trillion by volume; $\mathrm{pg} / \mathrm{kg}$, picogram per kilogram]

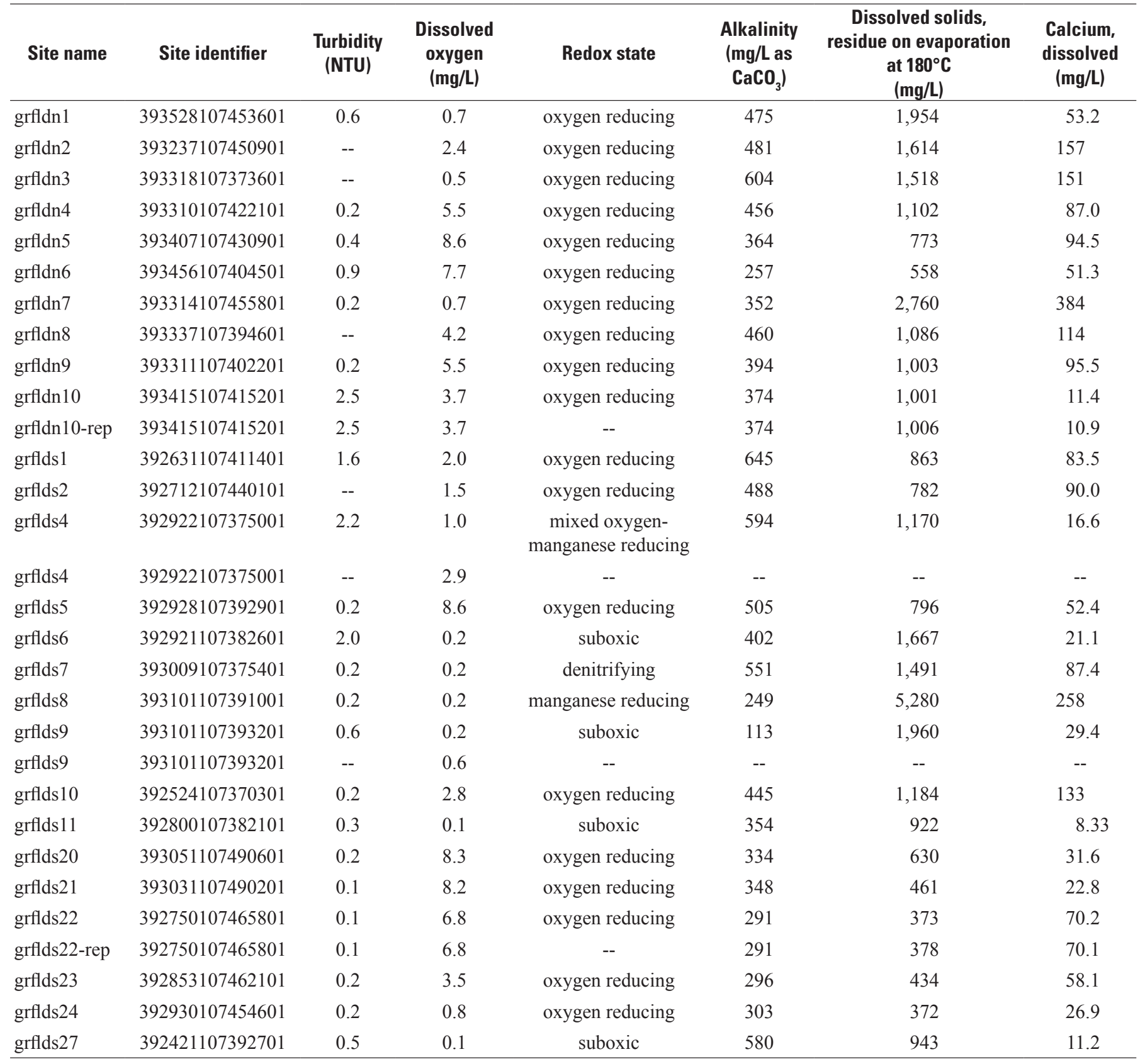

${ }^{1}$ Estimated (E) concentrations are those concentrations that are greater than or equal to the long-term method detection limit but less than the laboratory reporting level or lowest calibration standard, whichever is greater (Childress and others, 1999). 
Table 1. Chemical data for water collected from domestic wells in Garfield County, Colorado.—Continued

[NGVD29, North American Vertical Datum of $1929 ; \mathrm{m}$, meters; ${ }^{\circ} \mathrm{C}$, degrees Celsius; $\mu \mathrm{S} / \mathrm{cm}$, microsiemens per centimeter; mg/L, milligrams per liter; $\mathrm{CaCO}_{3}$, calcium carbonate; NTU, nephelometric turbidity units; <, less than; --, no data; E, estimated ${ }^{1} ; \mathrm{N}$, nitrogen; $\mathrm{P}$, phosphorus; $\mu \mathrm{g} / \mathrm{L}$, micrograms per liter; \%o, per mil; VSMOW, Vienna Standard Mean Ocean Water; TU, tritium units; VPDB, Vienna PeeDee Belemnite; mol \%, mole percent; $\mathrm{cm}^{3}$ STP/g, cubic centimeters at standard temperature and pressure, per gram of water; $\mathrm{R} / \mathrm{R}_{\mathrm{a}}$, helium-3/helium- 4 ratio in the sample divided by the helium-3/helium- 4 ratio in air; $\mathrm{cm}^{3} \mathrm{STP} / \mathrm{L}$, cubic centimeters at standard temperature and pressure, per liter of water; g, gram; fmol/L, femtomole per liter; pptv, parts per trillion by volume; $\mathrm{pg} / \mathrm{kg}$, picogram per kilogram]

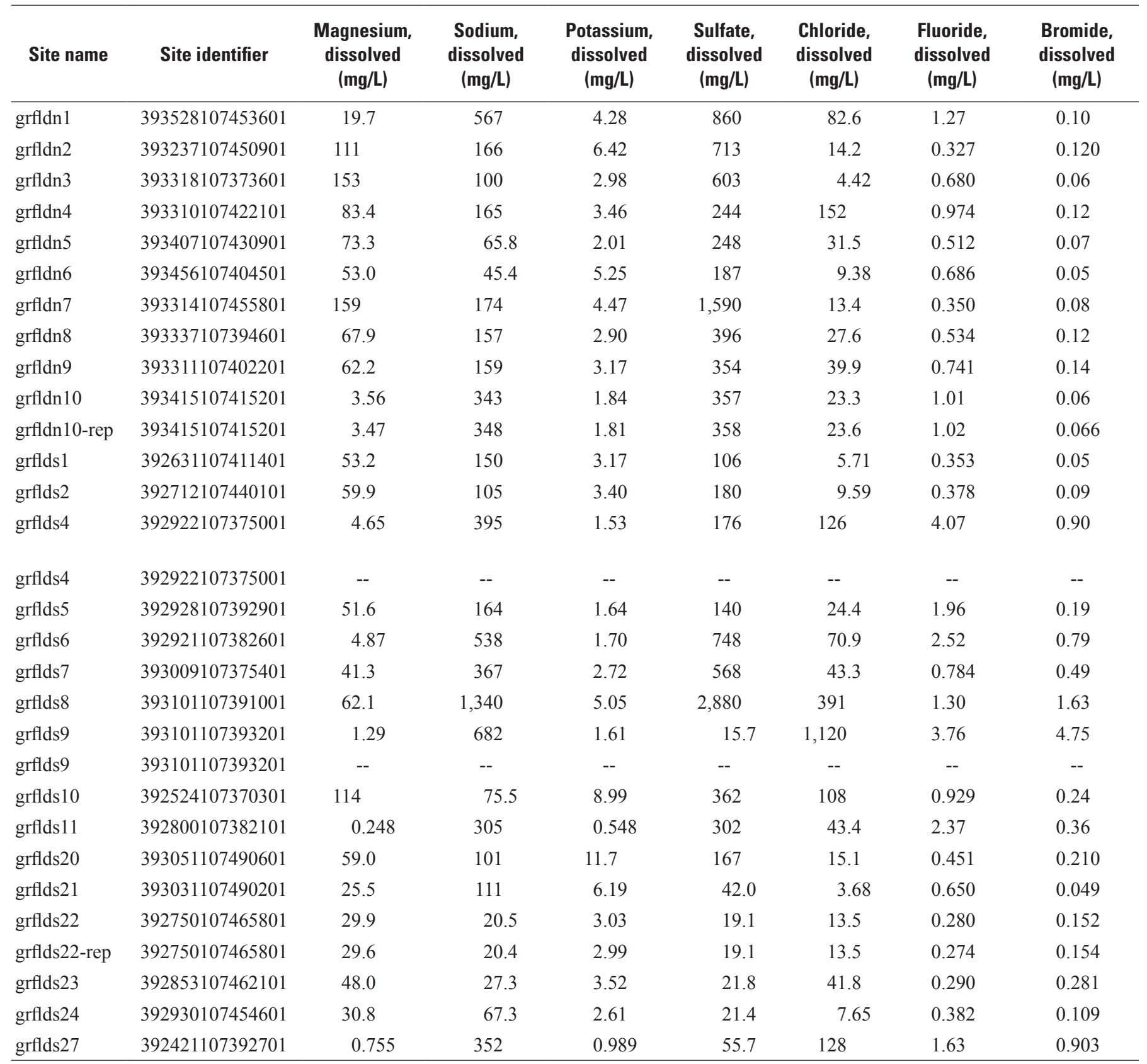

${ }^{1}$ Estimated (E) concentrations are those concentrations that are greater than or equal to the long-term method detection limit but less than the laboratory reporting level or lowest calibration standard, whichever is greater (Childress and others, 1999). 
Table 1. Chemical data for water collected from domestic wells in Garfield County, Colorado.-Continued

[NGVD29, North American Vertical Datum of 1929; m, meters; ${ }^{\circ} \mathrm{C}$, degrees Celsius; $\mu \mathrm{S} / \mathrm{cm}$, microsiemens per centimeter; $\mathrm{mg} / \mathrm{L}$, milligrams per liter; $\mathrm{CaCO}_{3}$, calcium carbonate; NTU, nephelometric turbidity units; <, less than; --, no data; E, estimated ${ }^{1} ; \mathrm{N}$, nitrogen; P, phosphorus; $\mu \mathrm{g} / \mathrm{L}$, micrograms per liter; \%, per mil; VSMOW, Vienna Standard Mean Ocean Water; TU, tritium units; VPDB, Vienna PeeDee Belemnite; mol \%, mole percent; $\mathrm{cm}^{3}$ STP/g, cubic centimeters at standard temperature and pressure, per gram of water; $\mathrm{R} / \mathrm{R}_{\mathrm{a}}$, helium-3/helium- 4 ratio in the sample divided by the helium-3/helium- 4 ratio in air; $\mathrm{cm}^{3} \mathrm{STP} / \mathrm{L}$, cubic centimeters at standard temperature and pressure, per liter of water; g, gram; fmol/L, femtomole per liter; pptv, parts per trillion by volume; $\mathrm{pg} / \mathrm{kg}$, picogram per kilogram]

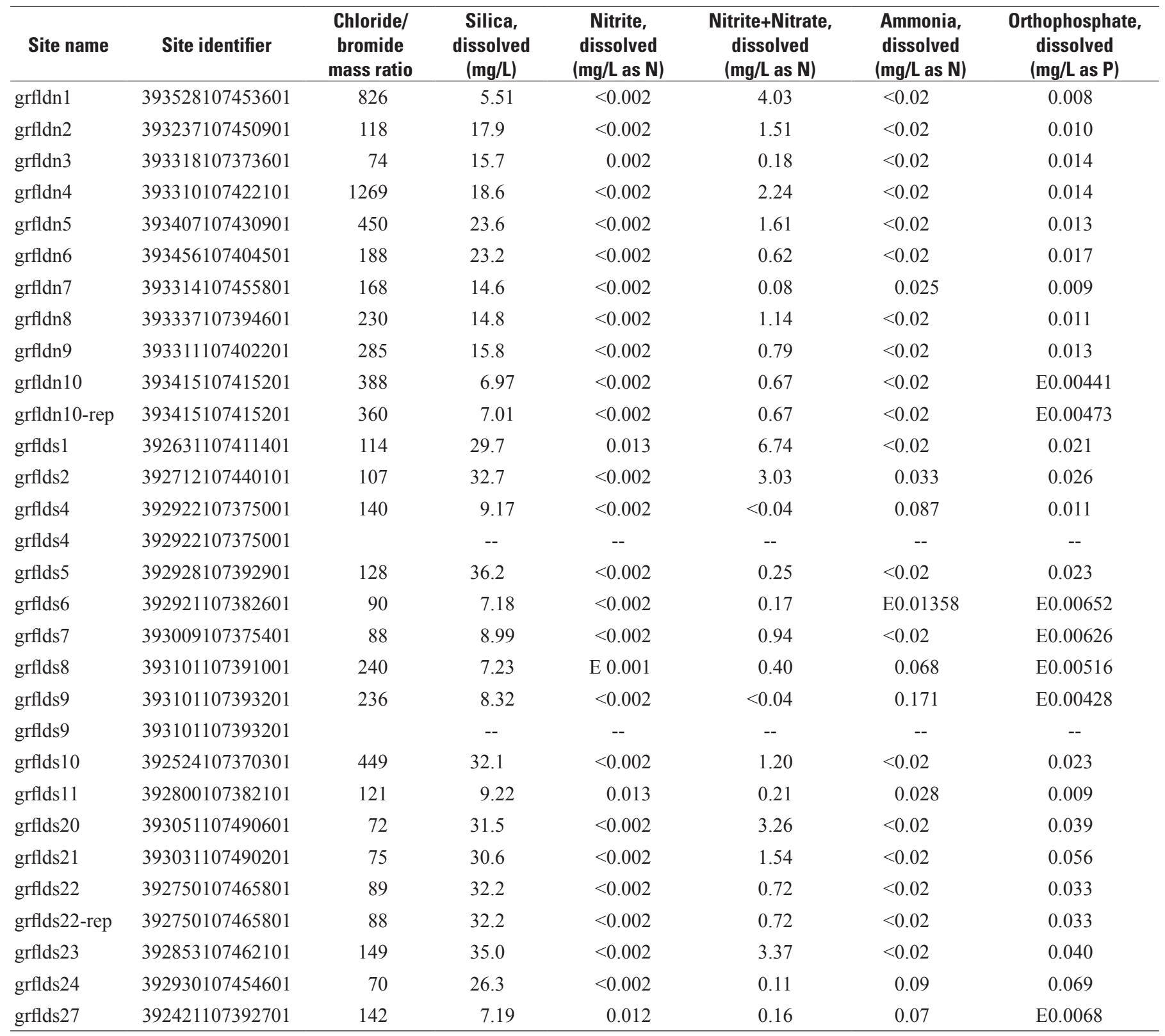

${ }^{1}$ Estimated (E) concentrations are those concentrations that are greater than or equal to the long-term method detection limit but less than the laboratory reporting level or lowest calibration standard, whichever is greater (Childress and others, 1999). 
Table 1. Chemical data for water collected from domestic wells in Garfield County, Colorado.—Continued

[NGVD29, North American Vertical Datum of $1929 ; \mathrm{m}$, meters; ${ }^{\circ} \mathrm{C}$, degrees Celsius; $\mu \mathrm{S} / \mathrm{cm}$, microsiemens per centimeter; mg/L, milligrams per liter; $\mathrm{CaCO}_{3}$, calcium carbonate; NTU, nephelometric turbidity units; <, less than; --, no data; E, estimated ${ }^{1} ; \mathrm{N}$, nitrogen; $\mathrm{P}$, phosphorus; $\mu \mathrm{g} / \mathrm{L}$, micrograms per liter; \%, per mil; VSMOW, Vienna Standard Mean Ocean Water; TU, tritium units; VPDB, Vienna PeeDee Belemnite; mol \%, mole percent; $\mathrm{cm}^{3}$ STP/g, cubic centimeters at standard temperature and pressure, per gram of water; $\mathrm{R} / \mathrm{R}_{\mathrm{a}}$, helium-3/helium-4 ratio in the sample divided by the helium-3/helium- 4 ratio in air; $\mathrm{cm}^{3} \mathrm{STP} / \mathrm{L}$, cubic centimeters at standard temperature and pressure, per liter of water; g, gram; fmol/L, femtomole per liter; pptv, parts per trillion by volume; $\mathrm{pg} / \mathrm{kg}$, picogram per kilogram]

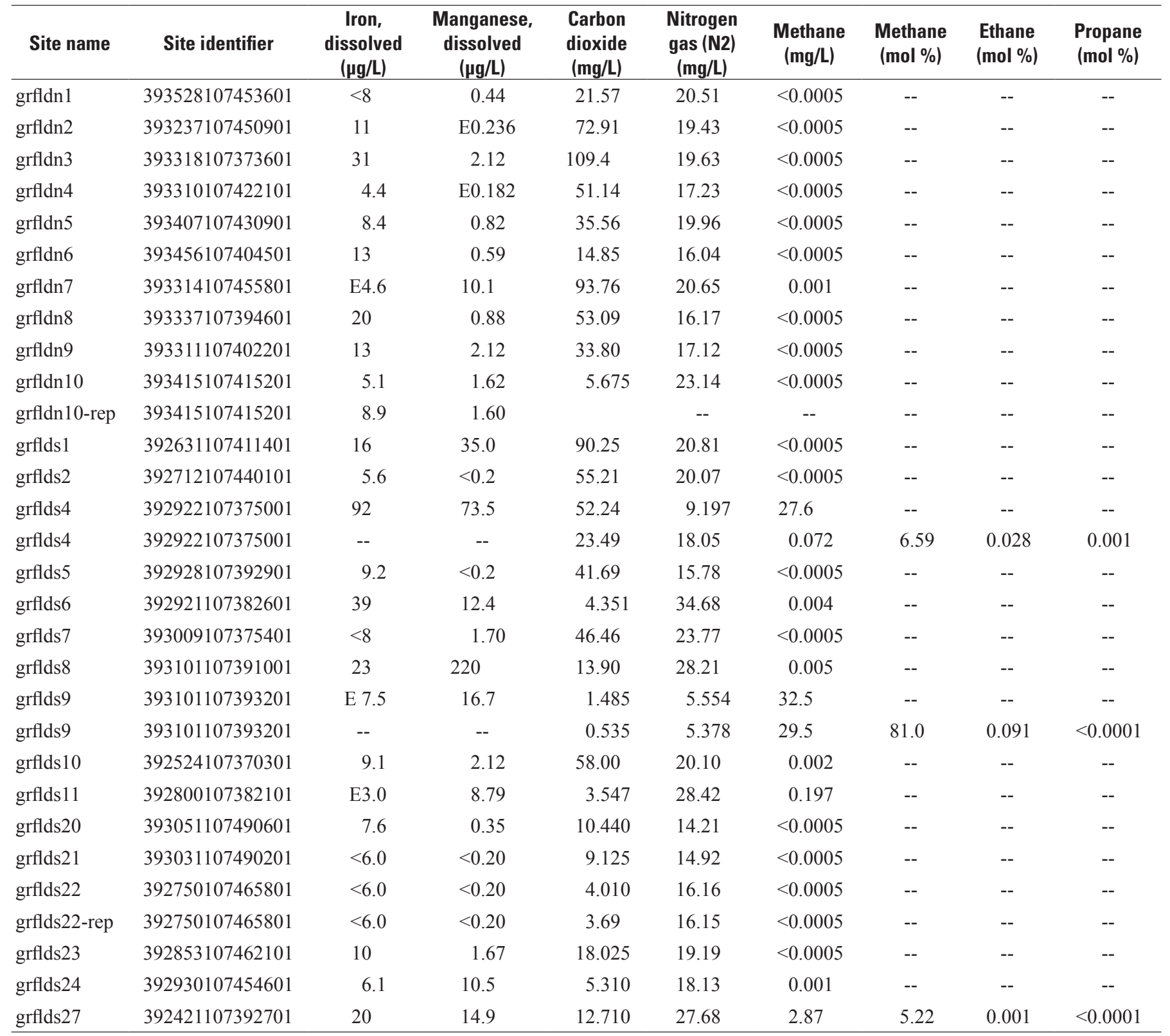

${ }^{1}$ Estimated (E) concentrations are those concentrations that are greater than or equal to the long-term method detection limit but less than the laboratory reporting level or lowest calibration standard, whichever is greater (Childress and others, 1999). 


\section{Use of Diverse Geochemical Data Sets in Groundwater, Garfield County, Colorado, 2009}

Table 1. Chemical data for water collected from domestic wells in Garfield County, Colorado._-Continued

[NGVD29, North American Vertical Datum of 1929; m, meters; ${ }^{\circ} \mathrm{C}$, degrees Celsius; $\mu \mathrm{S} / \mathrm{cm}$, microsiemens per centimeter; $\mathrm{mg} / \mathrm{L}$, milligrams per liter; $\mathrm{CaCO}_{3}$, calcium carbonate; NTU, nephelometric turbidity units; <, less than; --, no data; E, estimated ${ }^{1} ; \mathrm{N}$, nitrogen; P, phosphorus; $\mu \mathrm{g} / \mathrm{L}$, micrograms per liter; \%, per mil; VSMOW, Vienna Standard Mean Ocean Water; TU, tritium units; VPDB, Vienna PeeDee Belemnite; mol \%, mole percent; $\mathrm{cm}^{3}$ STP/g, cubic centimeters at standard temperature and pressure, per gram of water; $\mathrm{R} / \mathrm{R}_{\mathrm{a}}$, helium-3/helium- 4 ratio in the sample divided by the helium-3/helium- 4 ratio in air; $\mathrm{cm}^{3} \mathrm{STP} / \mathrm{L}$, cubic centimeters at standard temperature and pressure, per liter of water; g, gram; fmol/L, femtomole per liter; pptv, parts per trillion by volume; $\mathrm{pg} / \mathrm{kg}$, picogram per kilogram]

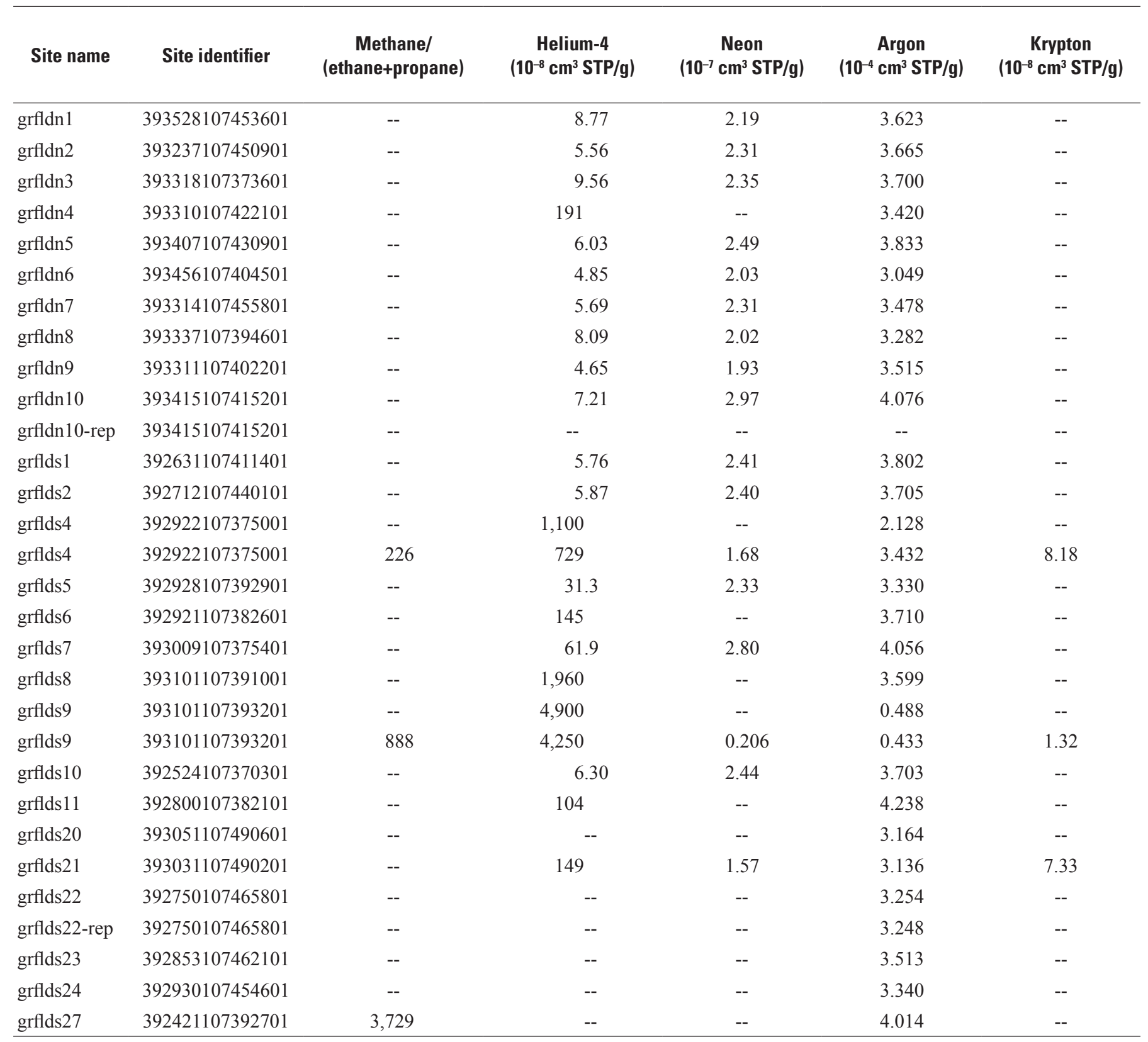

${ }^{1}$ Estimated (E) concentrations are those concentrations that are greater than or equal to the long-term method detection limit but less than the laboratory reporting level or lowest calibration standard, whichever is greater (Childress and others, 1999). 
Table 1. Chemical data for water collected from domestic wells in Garfield County, Colorado._-Continued

[NGVD29, North American Vertical Datum of $1929 ; \mathrm{m}$, meters; ${ }^{\circ} \mathrm{C}$, degrees Celsius; $\mu \mathrm{S} / \mathrm{cm}$, microsiemens per centimeter; mg/L, milligrams per liter; $\mathrm{CaCO}_{3}$, calcium carbonate; NTU, nephelometric turbidity units; <, less than; --, no data; E, estimated ${ }^{1}$; N, nitrogen; P, phosphorus; $\mu \mathrm{g} / \mathrm{L}$, micrograms per liter; \%, per mil; VSMOW, Vienna Standard Mean Ocean Water; TU, tritium units; VPDB, Vienna PeeDee Belemnite; mol \%, mole percent; $\mathrm{cm}^{3}$ STP/g, cubic centimeters at standard temperature and pressure, per gram of water; $\mathrm{R} / \mathrm{R}_{\mathrm{a}}$, helium-3/helium- 4 ratio in the sample divided by the helium-3/helium- 4 ratio in air; $\mathrm{cm}^{3} \mathrm{STP} / \mathrm{L}$, cubic centimeters at standard temperature and pressure, per liter of water; g, gram; fmol/L, femtomole per liter; pptv, parts per trillion by volume; $\mathrm{pg} / \mathrm{kg}$, picogram per kilogram]

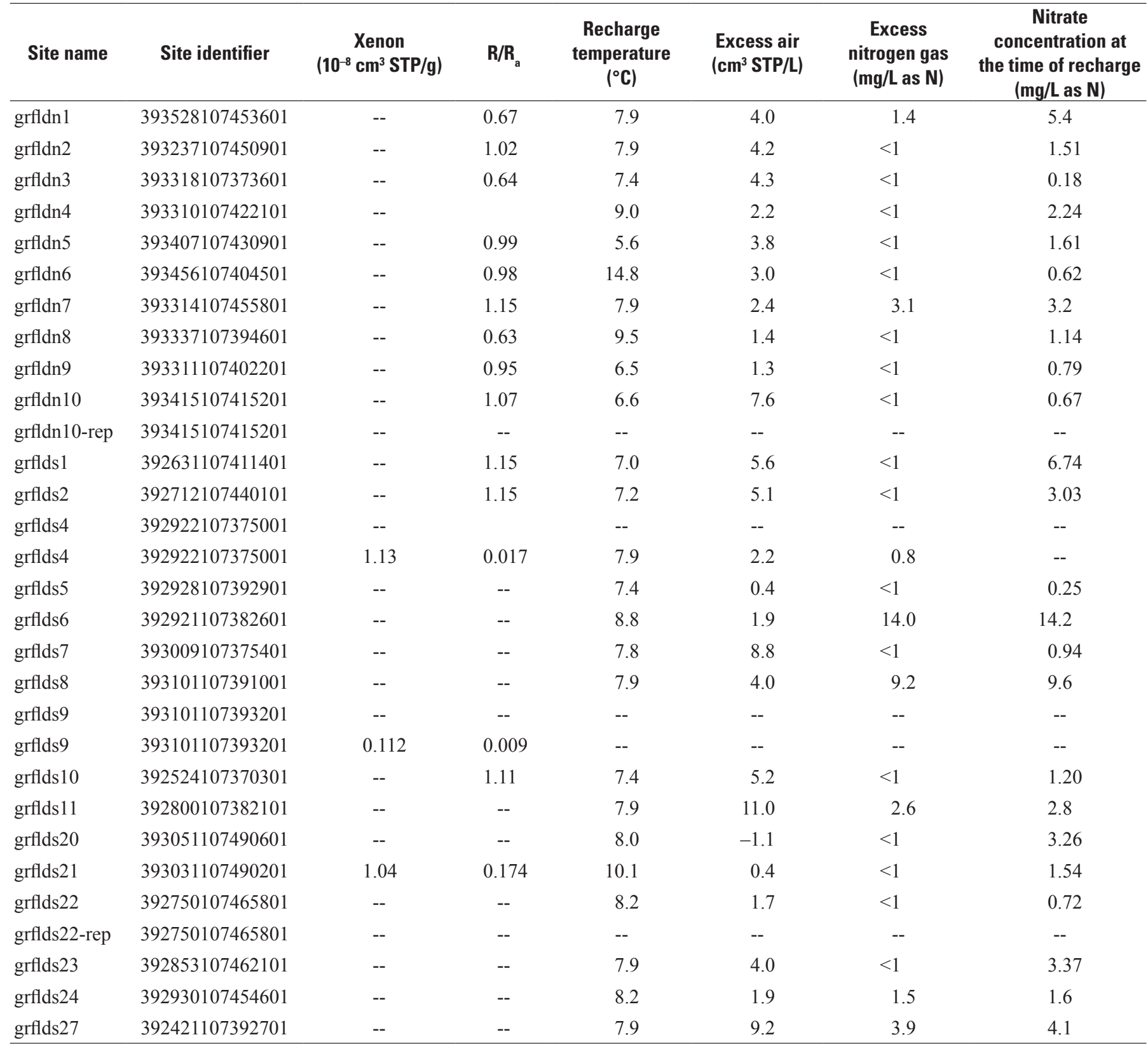

${ }^{1}$ Estimated (E) concentrations are those concentrations that are greater than or equal to the long-term method detection limit but less than the laboratory reporting level or lowest calibration standard, whichever is greater (Childress and others, 1999). 
Table 1. Chemical data for water collected from domestic wells in Garfield County, Colorado.-Continued

[NGVD29, North American Vertical Datum of 1929; m, meters; ${ }^{\circ} \mathrm{C}$, degrees Celsius; $\mu \mathrm{S} / \mathrm{cm}$, microsiemens per centimeter; $\mathrm{mg} / \mathrm{L}$, milligrams per liter; $\mathrm{CaCO}_{3}$, calcium carbonate; NTU, nephelometric turbidity units; <, less than; --, no data; E, estimated ${ }^{1} ; \mathrm{N}$, nitrogen; P, phosphorus; $\mu \mathrm{g} / \mathrm{L}$, micrograms per liter; \%, per mil; VSMOW, Vienna Standard Mean Ocean Water; TU, tritium units; VPDB, Vienna PeeDee Belemnite; mol \%, mole percent; $\mathrm{cm}^{3}$ STP/g, cubic centimeters at standard temperature and pressure, per gram of water; $\mathrm{R} / \mathrm{R}_{\mathrm{a}}$, helium-3/helium- 4 ratio in the sample divided by the helium-3/helium- 4 ratio in air; $\mathrm{cm}^{3} \mathrm{STP} / \mathrm{L}$, cubic centimeters at standard temperature and pressure, per liter of water; g, gram; fmol/L, femtomole per liter; pptv, parts per trillion by volume; $\mathrm{pg} / \mathrm{kg}$, picogram per kilogram]

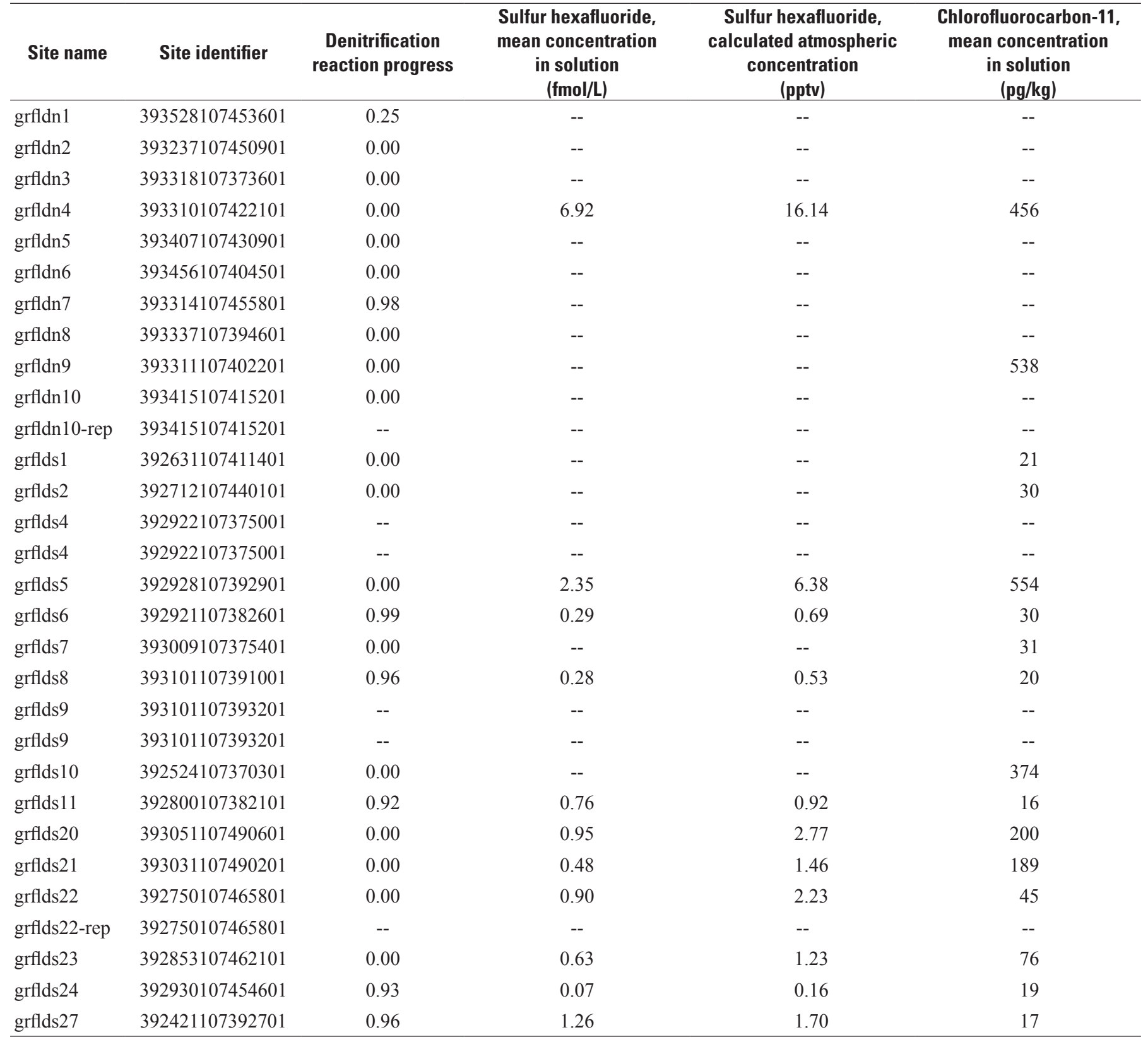

${ }^{1}$ Estimated (E) concentrations are those concentrations that are greater than or equal to the long-term method detection limit but less than the laboratory reporting level or lowest calibration standard, whichever is greater (Childress and others, 1999). 
Table 1. Chemical data for water collected from domestic wells in Garfield County, Colorado.-Continued

[NGVD29, North American Vertical Datum of $1929 ; \mathrm{m}$, meters; ${ }^{\circ} \mathrm{C}$, degrees Celsius; $\mu \mathrm{S} / \mathrm{cm}$, microsiemens per centimeter; mg/L, milligrams per liter; $\mathrm{CaCO}_{3}$, calcium carbonate; NTU, nephelometric turbidity units; <, less than; --, no data; E, estimated ${ }^{1} ; \mathrm{N}$, nitrogen; P, phosphorus; $\mu \mathrm{g} / \mathrm{L}$, micrograms per liter; \%o, per mil; VSMOW, Vienna Standard Mean Ocean Water; TU, tritium units; VPDB, Vienna PeeDee Belemnite; mol \%, mole percent; $\mathrm{cm}^{3}$ STP/g, cubic centimeters at standard temperature and pressure, per gram of water; $\mathrm{R} / \mathrm{R}_{\mathrm{a}}$, helium-3/helium- 4 ratio in the sample divided by the helium-3/helium- 4 ratio in air; $\mathrm{cm}^{3} \mathrm{STP} / \mathrm{L}$, cubic centimeters at standard temperature and pressure, per liter of water; g, gram; fmol/L, femtomole per liter; pptv, parts per trillion by volume; $\mathrm{pg} / \mathrm{kg}$, picogram per kilogram]

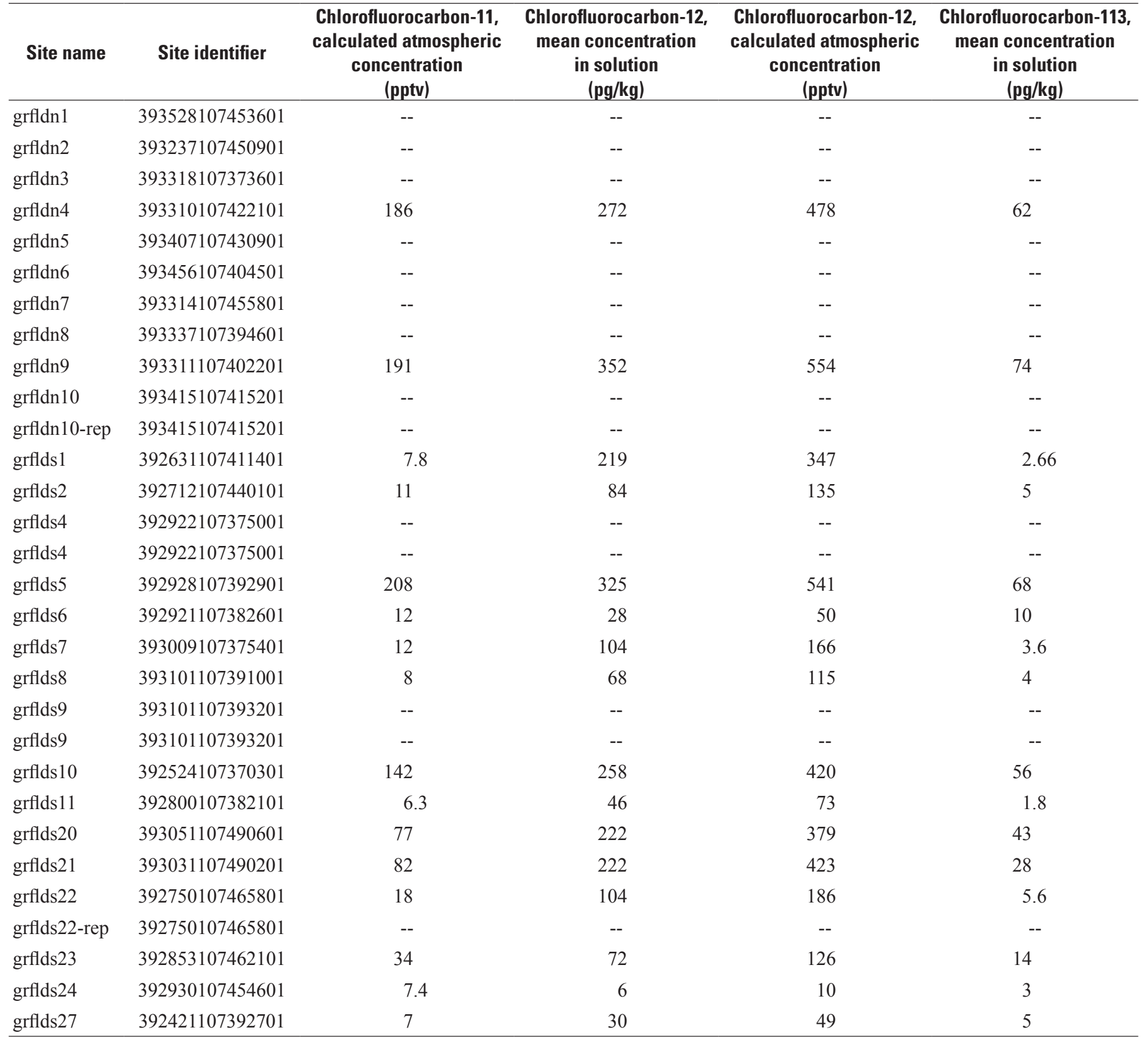

${ }^{1}$ Estimated (E) concentrations are those concentrations that are greater than or equal to the long-term method detection limit but less than the laboratory reporting level or lowest calibration standard, whichever is greater (Childress and others, 1999). 
Table 1. Chemical data for water collected from domestic wells in Garfield County, Colorado._-Continued

[NGVD29, North American Vertical Datum of $1929 ; \mathrm{m}$, meters; ${ }^{\circ} \mathrm{C}$, degrees Celsius; $\mu \mathrm{S} / \mathrm{cm}$, microsiemens per centimeter; mg/L, milligrams per liter; $\mathrm{CaCO}_{3}$, calcium carbonate; NTU, nephelometric turbidity units; <, less than; --, no data; E, estimated ${ }^{1} ; \mathrm{N}$, nitrogen; P, phosphorus; $\mu \mathrm{g} / \mathrm{L}$, micrograms per liter; \%, per mil; VSMOW, Vienna Standard Mean Ocean Water; TU, tritium units; VPDB, Vienna PeeDee Belemnite; mol \%, mole percent; $\mathrm{cm}^{3}$ STP/g, cubic centimeters at standard temperature and pressure, per gram of water; $\mathrm{R} / \mathrm{R}_{\mathrm{a}}$, helium-3/helium- 4 ratio in the sample divided by the helium-3/helium- 4 ratio in air; $\mathrm{cm}^{3} \mathrm{STP} / \mathrm{L}$, cubic centimeters at standard temperature and pressure, per liter of water; g, gram; fmol/L, femtomole per liter; pptv, parts per trillion by volume; $\mathrm{pg} / \mathrm{kg}$, picogram per kilogram]

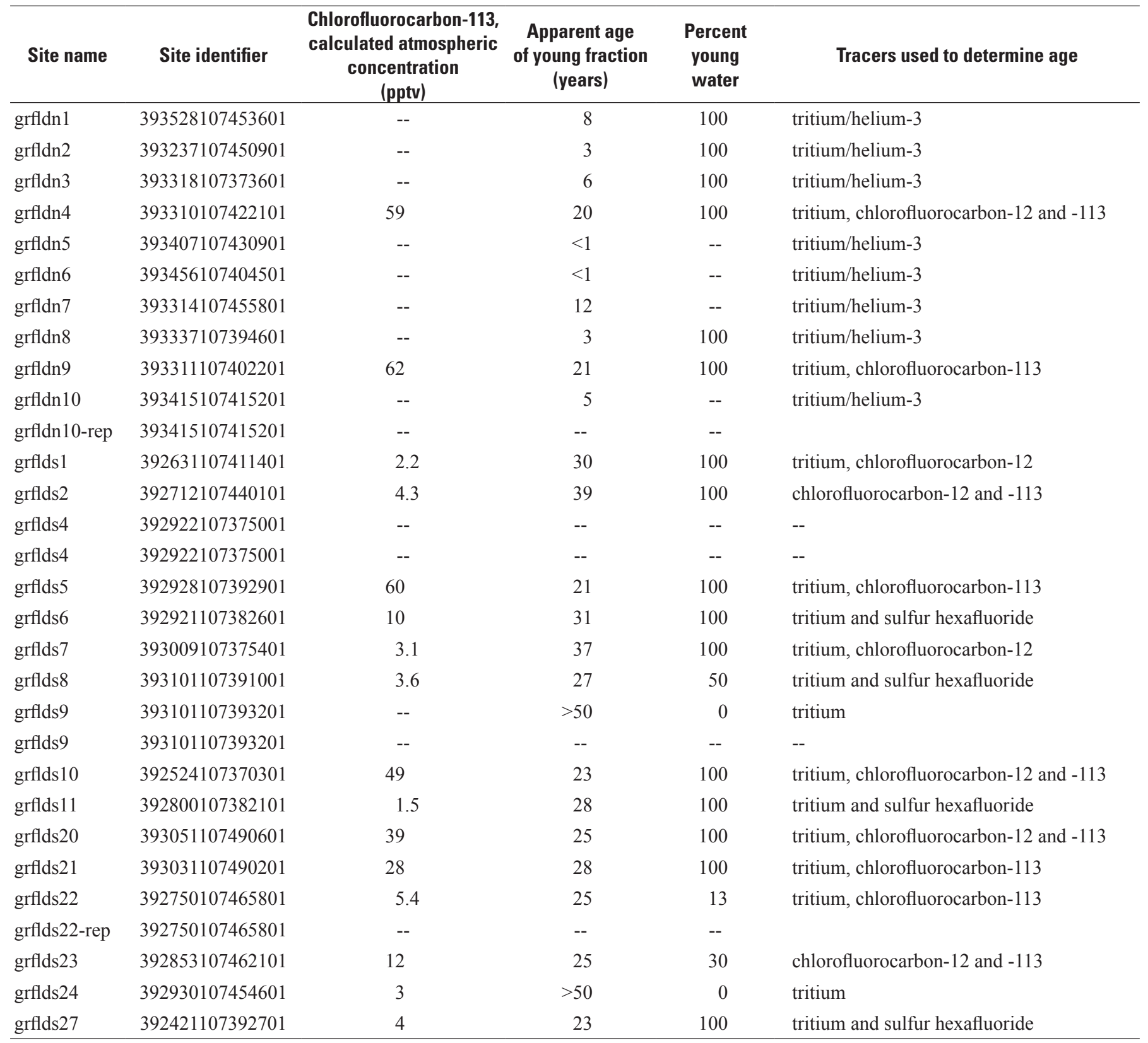

${ }^{1}$ Estimated (E) concentrations are those concentrations that are greater than or equal to the long-term method detection limit but less than the laboratory reporting level or lowest calibration standard, whichever is greater (Childress and others, 1999). 
Table 1. Chemical data for water collected from domestic wells in Garfield County, Colorado.-Continued

[NGVD29, North American Vertical Datum of $1929 ; \mathrm{m}$, meters; ${ }^{\circ} \mathrm{C}$, degrees Celsius; $\mu \mathrm{S} / \mathrm{cm}$, microsiemens per centimeter; mg/L, milligrams per liter; $\mathrm{CaCO}_{3}$, calcium carbonate; NTU, nephelometric turbidity units; <, less than; --, no data; E, estimated ${ }^{1} ; \mathrm{N}$, nitrogen; P, phosphorus; $\mu \mathrm{g} / \mathrm{L}$, micrograms per liter; \%o, per mil; VSMOW, Vienna Standard Mean Ocean Water; TU, tritium units; VPDB, Vienna PeeDee Belemnite; mol \%, mole percent; $\mathrm{cm}^{3}$ STP/g, cubic centimeters at standard temperature and pressure, per gram of water; $\mathrm{R} / \mathrm{R}_{\mathrm{a}}$, helium-3/helium- 4 ratio in the sample divided by the helium- $3 /$ helium- 4 ratio in air; $\mathrm{cm}^{3} \mathrm{STP} / \mathrm{L}$, cubic centimeters at standard temperature and pressure, per liter of water; g, gram; fmol/L, femtomole per liter; pptv, parts per trillion by volume; $\mathrm{pg} / \mathrm{kg}$, picogram per kilogram]

\begin{tabular}{|c|c|c|c|}
\hline Site name & Site identifier & Model used to determine age & Age comment \\
\hline grfldn1 & 393528107453601 & piston-flow model & minimum age, tritiogenic helium-3 degassing likely \\
\hline grfldn2 & 393237107450901 & piston-flow model & minimum age, tritiogenic helium-3 degassing likely \\
\hline grfldn3 & 393318107373601 & piston-flow model & minimum age, tritiogenic helium-3 degassing likely \\
\hline grfldn4 & 393310107422101 & piston-flow model & \\
\hline grfldn5 & 393407107430901 & piston-flow model & minimum age, tritiogenic helium-3 degassing likely \\
\hline grfldn6 & 393456107404501 & piston-flow model & minimum age, tritiogenic helium-3 degassing likely \\
\hline grfldn 7 & 393314107455801 & piston-flow model & minimum age, tritiogenic helium-3 degassing likely \\
\hline grfldn8 & 393337107394601 & piston-flow model & minimum age, tritiogenic helium-3 degassing likely \\
\hline grfldn9 & 393311107402201 & piston-flow model & \\
\hline grfldn 10 & 393415107415201 & piston-flow model & minimum age, tritiogenic helium-3 degassing likely \\
\hline grfldn10-rep & 393415107415201 & & \\
\hline grflds 1 & 392631107411401 & exponential mixing model & \\
\hline grflds2 & 392712107440101 & piston-flow model & \\
\hline grflds4 & 392922107375001 & -- & high methane, gas stripped \\
\hline grflds4 & 392922107375001 & -- & high methane, gas stripped \\
\hline grflds5 & 392928107392901 & piston-flow model & \\
\hline grflds6 & 392921107382601 & piston-flow model & \\
\hline grflds 7 & 393009107375401 & piston-flow model & low dissolved oxygen, chlorofluorocarbon-12 could be degraded \\
\hline grflds 8 & 393101107391001 & binary-mixing model & \\
\hline grflds9 & 393101107393201 & -- & \\
\hline grflds9 & 393101107393201 & -- & \\
\hline grflds 10 & 392524107370301 & piston-flow model & \\
\hline grflds11 & 392800107382101 & piston-flow model & \\
\hline grflds 20 & 393051107490601 & piston-flow model & \\
\hline grflds 21 & 393031107490201 & piston-flow model & \\
\hline grflds 22 & 392750107465801 & binary-mixing model & \\
\hline grflds22-rep & 392750107465801 & & \\
\hline grflds 23 & 392853107462101 & binary-mixing model & \\
\hline grflds 24 & 392930107454601 & -- & \\
\hline grflds 27 & 392421107392701 & piston-flow model & \\
\hline
\end{tabular}

${ }^{1}$ Estimated (E) concentrations are those concentrations that are greater than or equal to the long-term method detection limit but less than the laboratory reporting level or lowest calibration standard, whichever is greater (Childress and others, 1999). 
Table 1. Chemical data for water collected from domestic wells in Garfield County, Colorado.-Continued

[NGVD29, North American Vertical Datum of $1929 ; \mathrm{m}$, meters; ${ }^{\circ} \mathrm{C}$, degrees Celsius; $\mu \mathrm{S} / \mathrm{cm}$, microsiemens per centimeter; mg/L, milligrams per liter; $\mathrm{CaCO}_{3}$, calcium carbonate; NTU, nephelometric turbidity units; <, less than; --, no data; E, estimated ${ }^{1} ; \mathrm{N}$, nitrogen; P, phosphorus; $\mu \mathrm{g} / \mathrm{L}$, micrograms per liter; \%, per mil; VSMOW, Vienna Standard Mean Ocean Water; TU, tritium units; VPDB, Vienna PeeDee Belemnite; mol \%, mole percent; $\mathrm{cm}^{3}$ STP/g, cubic centimeters at standard temperature and pressure, per gram of water; $\mathrm{R} / \mathrm{R}_{\mathrm{a}}$, helium-3/helium- 4 ratio in the sample divided by the helium-3/helium- 4 ratio in air; $\mathrm{cm}^{3} \mathrm{STP} / \mathrm{L}$, cubic centimeters at standard temperature and pressure, per liter of water; g, gram; fmol/L, femtomole per liter; pptv, parts per trillion by volume; $\mathrm{pg} / \mathrm{kg}$, picogram per kilogram]

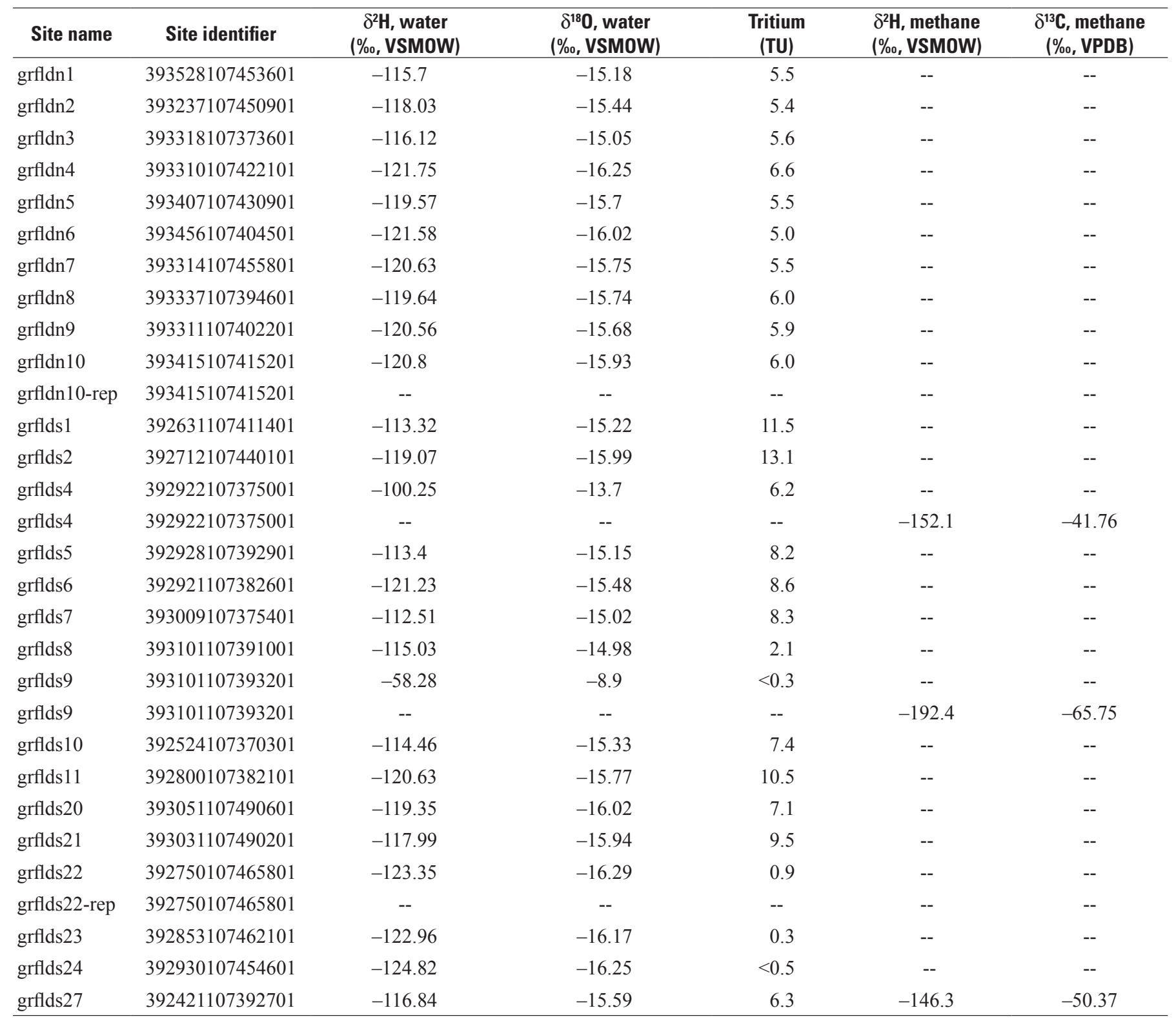

${ }^{1}$ Estimated (E) concentrations are those concentrations that are greater than or equal to the long-term method detection limit but less than the laboratory reporting level or lowest calibration standard, whichever is greater (Childress and others, 1999). 
For samples with dissolved-oxygen concentrations less than or equal to $2 \mathrm{mg} / \mathrm{L}$, excess nitrogen gas from denitrification was calculated according to equation 2 :

$$
\begin{gathered}
\text { Excess } \mathrm{N}_{2}=\mathrm{N}_{2}(\text { measured }) \\
-\mathrm{N}_{2} \text { (equilibrium) }-\mathrm{N}_{2} \text { (excess air) }
\end{gathered}
$$

where

Excess $\mathrm{N}_{2}$ is the concentration of excess nitrogen gas from denitrification in the sample,

$\mathrm{N}_{2}$ (measured) is the measured concentration of nitrogen gas in the sample,

$\mathrm{N}_{2}$ (equilibrium) is the concentration of nitrogen gas from equilibration with the atmosphere in the sample (calculated for each sample on the basis of its recharge temperature and elevation, and salinity),

and

$\mathrm{N}_{2}$ (excess air) is the concentration of nitrogen gas from excess air in the sample.

The initial nitrate concentration (Initial nitrate) in the sample at the time it recharged the aquifer was calculated according to equation 3 :

$$
\text { Initial nitrate }=\text { Measured nitrate }+ \text { Excess } \mathrm{N}_{2}
$$

Measured nitrate is the measured concentration of nitrate in the sample. If the sample was not affected by denitrification then Excess $\mathrm{N}_{2}$ equals zero, and Initial nitrate equals Measured nitrate. An estimate of the extent to which nitrate was removed from groundwater by denitrification was calculated according to equation 4 :

$$
\begin{gathered}
\text { Denitrification reaction progress }=1 \\
-(\text { Measured nitrate/Initial nitrate })
\end{gathered}
$$

Denitrification reaction progress would equal zero if no nitrate was removed by denitrification, and it would equal one if all the nitrate was removed by denitrification.

\section{Groundwater Age}

Groundwater ages calculated from environmental tracers like tritium, chlorofluorocarbons, sulfur hexafluoride, and tritium/helium-3 are referred to as "apparent ages" because they are based on simplifying assumptions regarding transport processes that may affect tracer concentrations in groundwater (Plummer and Busenberg, 2000; Rupert and Plummer, 2009). The most straightforward assumption is that transport processes (for example, mixing or dispersion) have no effect on the concentration of tracers as they move in an aquifer. Thus the tracer concentration in water at the sampling point (such as a well) is the same as the concentration at the time the water recharged the aquifer. This model is referred to as the "pistonflow model." The piston-flow model appears to be a reasonable representation of groundwater age in some instances, such as in shallow, short-screened wells. In other instances, mixing or dispersion affect measured tracer concentrations, particularly for wells with long-screened intervals. The simplest model describing the effect of mixing on tracer concentrations is the binary-mixing model, which assumes the water is a mixture of old (pretracer or pre 1950s) water and young water (containing tracer or post 1950s). More complicated models of mixing assume the sampled water represents a distribution of ages. These models, called lumped-parameter models, yield a mean age of the water sample. Perhaps the most common lumped-parameter model is the exponential model (Maloszewski and Zuber, 1982, 1996; Cook and Böhlke, 2000). The exponential model could describe the mean age of water discharged from a long-screened well in an unconfined aquifer receiving distributed recharge, for example.

The following sections discuss in more specific terms the application of tritium, chlorofluorocarbons, sulfur hexafluoride, and tritium/helium-3 tracers to groundwater dating. These tracers were used to determine apparent ages of young (generally, post 1950s) groundwater and the dilution of young groundwater with old (pre 1950s) groundwater.

Tritium.- Tritium is a radioactive isotope of hydrogen with a half-life of 12.32 years (Lucas and Unterweger, 2000). Small concentrations of tritium are produced naturally by interactions between the atmosphere and cosmic rays. It is an excellent tracer of water movement because it is part of the water molecule. In general, tritium in groundwater originates from precipitation. Because tritium is radioactive, its concentration in groundwater decreases over time because of radioactive decay. Before the onset of atmospheric testing of nuclear weapons in 1953 (prebomb), the tritium content of precipitation in the central United States probably ranged from about 3 to 8 tritium units (TU) (Kaufman and Libby, 1954; Thatcher, 1962). As a result of radioactive decay, groundwater derived from precipitation that fell before 1953 would have contained less than $0.5 \mathrm{TU}$ tritium in 2010. The tritium content of precipitation increased substantially after the onset of atmospheric nuclear weapons testing with the addition of bomb tritium but has slowly decreased from its peak in the early 1960s (fig. 3). Even with the variability in tritium content of precipitation over time, groundwater totally derived from precipitation that fell since 1953 (postbomb) contained more than 0.5 TU in 2010 .

Chlorofluorocarbons. - Chlorofluorocarbons are stable synthetic organic compounds that were used as refrigerants and in other industrial applications beginning in the 1930s (Plummer and Busenberg, 2000). Concentrations of chlorofluorocarbons in the atmosphere rose sharply in the 1960s and peaked in the early 1990s (Plummer and Busenberg, 2000; Plummer and others, 2006) (fig. 3). The use of 


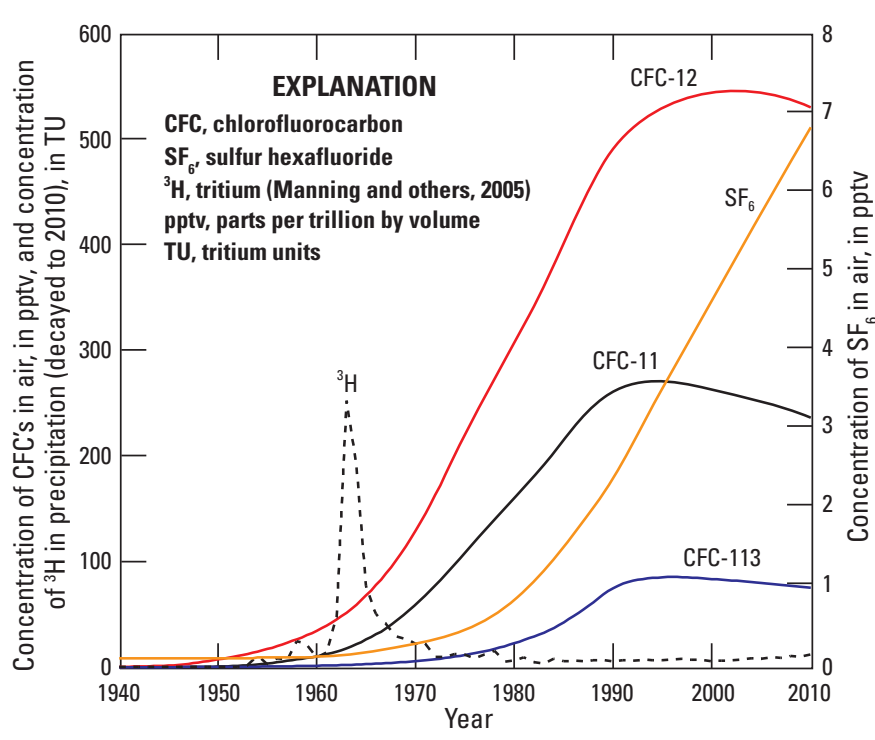

Figure 3. Concentrations of chlorofluorocarbons and sulfur hexafluoride in North American air, and concentrations of tritium in precipitation at Salt Lake City, Utah, decayed to 2010.

chlorofluorocarbons to determine groundwater age depends on relating their concentrations in groundwater to atmospheric concentrations in the recharge area at the time of recharge.

The concentration of chlorofluorocarbons in the atmosphere at the time a sample recharged the aquifer can be back calculated using the measured chlorofluorocarbon concentrations in the sample; the recharge temperature and excess-air concentration determined from the nitrogen-gas and argon concentrations, as discussed in the Sample Analysis section; salinity; recharge elevation; and Henry's Law. The year of recharge is determined by referring the back-calculated atmospheric concentration to a curve of the atmosphericconcentration history and picking the year corresponding to the back-calculated concentration (fig. 3). Apparent age simply is the sample date minus the recharge date. Since the early to mid 1990s, atmospheric concentrations of chlorofluorocarbons have begun to level off or decline (fig. 3), greatly limiting their use as age tracers for water recharged during that period. Details of the chlorofluorocarbon-dating method, including a discussion of subsurface processes that could produce erroneous apparent ages, can be found in Plummer and Busenberg (2000) and Plummer and others (2006). One such process relevant to the current study is chlorofluorocarbon biodegradation in anoxic groundwater. Biodegradation would reduce chlorofluorocarbon concentrations in groundwater and result in the calculated ages being biased old.

Sulfur Hexafluoride.- Sulfur hexafluoride is a stable gas that mainly has been used as an electrical insulator in high-voltage switches and transformers. It was produced in significant quantities beginning in the 1950s (Busenberg and Plummer, 2000). Release of sulfur hexafluoride to the atmosphere rose sharply in the 1980s and is ongoing (fig. 3).
Dating groundwater with sulfur hexafluoride essentially follows the same principals as chlorofluorocarbon dating. Two advantages of sulfur hexafluoride over chlorofluorocarbons are that sulfur hexafluoride does not degrade under anoxic conditions and it can be used as a tracer of groundwater age for water recharged since the 1990s because of its continued increase in the atmosphere during that period. Details of the sulfur-hexafluoride dating method, including a discussion of subsurface processes that could produce erroneous apparent ages, can be found in Busenberg and Plummer (2000).

Tritium/Helium-3.-Helium-3 is produced from the radioactive decay of tritium. As discussed previously, tritium in groundwater recharged since the early 1950 s is dominated by bomb tritium. Helium-3 derived from the decay of bomb tritium is referred to as "tritiogenic helium-3". Given that the half-life of tritium is well known (12.32 years), if the amount of bomb tritium and tritiogenic helium- 3 in a sample can be measured then the apparent age of that sample can be calculated using a form of the radioactive-decay equation (Solomon and Cook, 2000). Whereas the tritium concentration in a sample can be measured directly, the tritiogenic helium-3 concentration in a sample must be calculated from mass balances on helium- 3 and helium- 4 concentrations, and the helium-3/helium-4 ratios of the predominant helium sources in the system. Typically, these helium sources include the atmosphere (helium-3/helium-4 $=1.384 \times 10^{-6}$; Clarke and others, 1976) and the decay of uranium and thorium in rocks and minerals in the earth's crust (helium-3/helium- $4=2 \times 10^{-8}$; Mamyrin and Tolstikhin, 1984). In some instances, mantle helium also is important (helium-3/helium-4 $=\sim 1 \times 10^{-5}$; Ozima and Podosek, 1983). Helium mass balance is necessary because the vast majority (usually greater than 99.9 percent) of the measured helium in a groundwater sample is helium-4. Moreover, the helium-4 content of groundwater typically increases over time because of helium- 4 production in the sediment from uranium and thorium decay. For tritium/helium-3 dating in this study, it was assumed that the earth's crust was the only subsurface source of helium (in other words, no mantle helium), with a helium-3/helium-4 ratio of $2 \times 10^{-8}$. The basis for this assumption is discussed in more detail in the Helium Concentrations and Isotopes section of this report. Details of the tritium/helium-3 dating method, including a discussion of subsurface processes that could produce erroneous apparent ages, can be found in Schlosser and others (1988, 1989), Solomon and Cook (2000), Böhlke and others (2007), and McMahon and others (2010). One such process relevant to the current study is incomplete tritiogenic helium-3 confinement in the aquifer because of low recharge rates. Tritiogenic helium- 3 could diffuse across the water table and exit the system if recharge rates were too low to trap it below the water table. Incomplete tritiogenic helium-3 confinement would result in the calculated ages being biased young. 


\section{Geochemical Data Sets}

This section describes and compares the spatial distributions of oxygen, nitrate, methane, and geochemical water types (based on major-ion data) in the Wasatch Formation.

\section{Distributions of Oxygen, Nitrate, and Methane in Groundwater}

Concentrations of dissolved oxygen in water from the sampled wells ranged from 0.1 to $8.6 \mathrm{mg} / \mathrm{L}$ (table 1 ), with the lowest concentrations occurring in a north-south trending zone located south of Silt (fig. 4). All the samples collected north of the Colorado River and 9 of 16 samples collected south of the river were considered to be oxygen reducing, or oxic (dissolved oxygen concentration greater than or equal to $0.5 \mathrm{mg} / \mathrm{L}$ ), on the basis of the redox classification scheme of McMahon and Chapelle (2008) (table 1). Of the remaining 7 samples collected south of the river, 4 were classified as suboxic, 1 was manganese reducing, 1 was a mixture of oxygen and manganese reducing, and 1 was denitrifying (table 1).

Concentrations of nitrite in most of the samples were less than the reporting level of $0.002 \mathrm{mg} / \mathrm{L}$ as $\mathrm{N}$ (table 1); therefore, concentrations of nitrite plus nitrate consisted almost entirely of nitrate and will be referred to as such for the remainder of this report. Concentrations of nitrate ranged from less than 0.04 to $6.74 \mathrm{mg} / \mathrm{L}$ as $\mathrm{N}$ (table 1). Nitrate concentrations in water samples with dissolved-oxygen concentrations less than $0.5 \mathrm{mg} / \mathrm{L}$ were significantly $(\mathrm{p}=0.03)$ lower than nitrate concentrations in water samples with dissolved-oxygen concentrations greater than or equal to $0.5 \mathrm{mg} / \mathrm{L}$ on the basis of the nonparametric Wilcoxon rank sum test (Helsel and Hirsch, 1992). Some of the lowest nitrate concentrations occurred in the north-south trending zone of low dissolved-oxygen concentrations located south of Silt (fig. 5). In contrast, that zone hosted the highest methane concentrations (fig. 6). Overall, methane concentrations ranged from less than 0.0005 to $32.5 \mathrm{mg} / \mathrm{L}$ (table 1 ) and were significantly $(p=0.007)$ higher in water samples with dissolved-oxygen concentrations less than $0.5 \mathrm{mg} / \mathrm{L}$ than in samples with dissolvedoxygen concentrations greater than or equal to $0.5 \mathrm{mg} / \mathrm{L}$. This pattern of low nitrate and high methane concentrations in groundwater containing little or no dissolved oxygen can be explained by the general principals of redox chemistry. Nitrate, presumably from anthropogenic or natural sources at the land surface, is likely to be degraded by denitrifying bacteria in anoxic groundwater (Chapelle and others, 1995; McMahon and Chapelle, 2008). In contrast, the potential for local biogenic methane production is greater in anoxic groundwater than in oxic groundwater. Methane produced externally by biogenic or thermogenic processes, and subsequently transported to the aquifer by natural or anthropogenic processes, also would be more likely to persist in anoxic groundwater than in oxic groundwater because of the possibility of methane degradation (oxidation) by methanotrophic bacteria in oxic groundwater (Barker and Fritz, 1981; Whiticar, 1999). Anoxic methane oxidation also may occur in aquifers, but generally that process is more common in marine sediments (Smith and others, 1991; Zhang and others, 1998; Whiticar, 1999; Grossman and others, 2002; Van Stempvoort and others, 2005). The processes of denitrification and methane oxidation are discussed in more detail in the Sources and Sinks of Nitrate in Groundwater and the Sources and Sinks of Methane in Groundwater sections of this report.

In general, the data in figures 4-6 indicate that field measurements of dissolved oxygen in groundwater could be useful indicators of the Wasatch Formation's vulnerability to nitrate and methane contamination, or enrichment in the case of naturally derived constituents. Oxic parts of the aquifer would be relatively more vulnerable to nitrate contamination and less vulnerable to methane contamination. Anoxic parts of the aquifer would be relatively less vulnerable to nitrate contamination and more vulnerable to methane contamination.

\section{Major-Ion Chemistry}

Water samples containing less than $1 \mathrm{mg} / \mathrm{L}$ methane and collected north of the Colorado River generally were mixedcation-sulfate-bicarbonate waters, whereas low-methane samples collected south of the river mostly were mixedcation-bicarbonate-sulfate waters (fig. 7). Three wells located south of the river (grflds4, grflds9, and grflds27) produced water with more than $1 \mathrm{mg} / \mathrm{L}$ methane, and they were sodiumbicarbonate to sodium-chloride waters (fig. 7). Of those samples, the one from grflds 9 appeared to be closest in majorion composition to produced water from the Mesaverde Group (fig. 7). Well grflds9 was screened from 120 to $134 \mathrm{~m}$ below land surface, which is considerably deeper than all the other wells except grflds4 (screened from 120 to $151 \mathrm{~m}$ below land surface) (table 1). Samples from two wells located north of the river (grfldn1 and grfldn10) and three wells located south of the river (grflds6, grflds8, and grflds11) also were relatively enriched in sodium but did not have methane concentrations greater than $1 \mathrm{mg} / \mathrm{L}$ (fig. 7).

The major-ion chemistry of water collected for this study showed similar overall patterns to the chemistry of water collected from domestic wells during previous studies (fig. 8). The data in figure 8 were retrieved from the U.S. Geological Survey Piceance Basin common data repository (U.S. Geological Survey, 2010b). Many of the wells in the data repository were sampled on more than one date so only the most recent sample with complete data was used in figure 8 . This same approach was used for other figures in the report in which data from the common data repository were displayed. Many of the previously collected samples containing less than $1 \mathrm{mg} / \mathrm{L}$ methane were mixed-cation-bicarbonatesulfate waters, but several low-methane waters also were relatively enriched in sodium. Most of the high-methane waters were relatively enriched in sodium as well. 

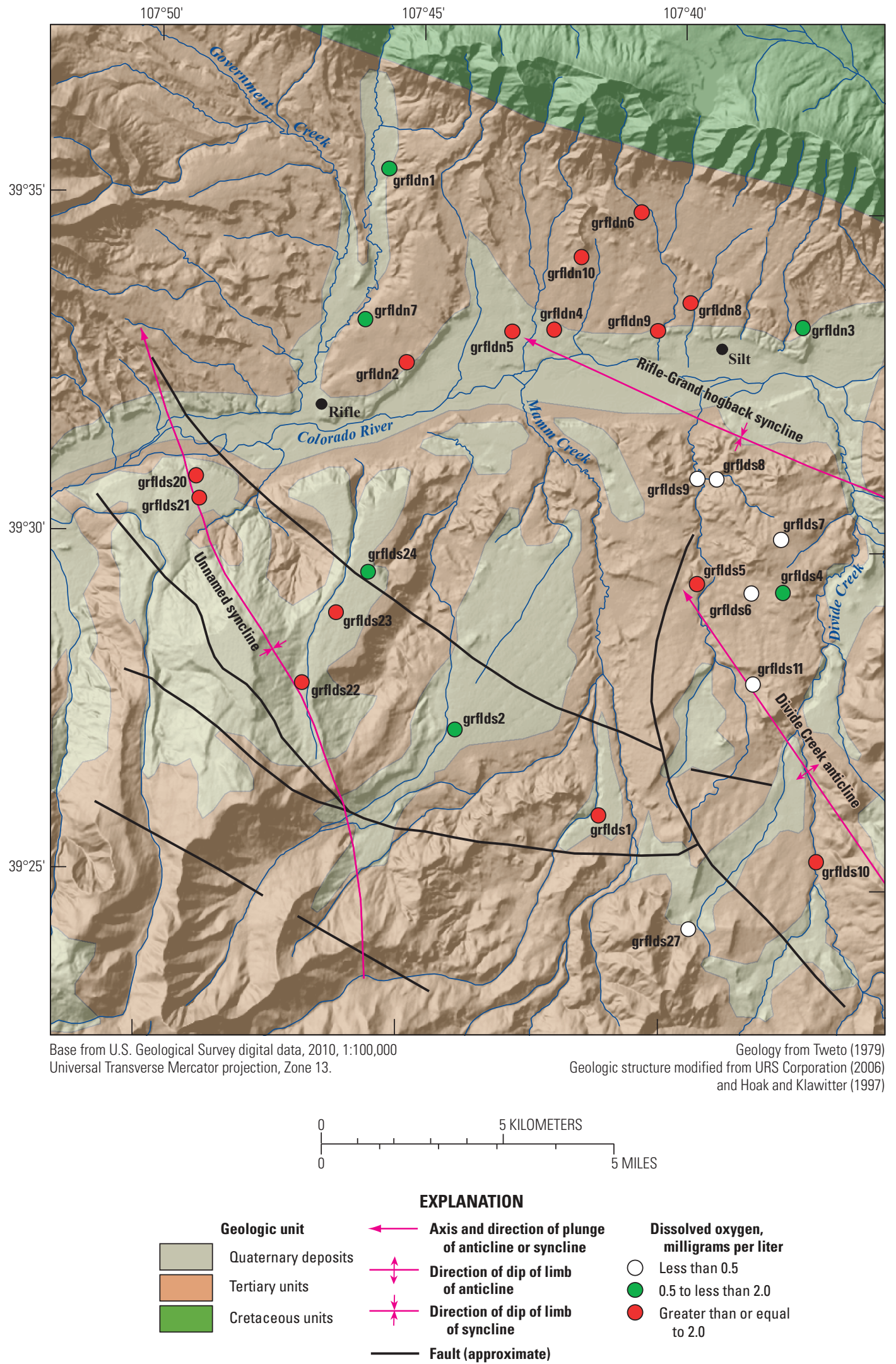

Figure 4. Concentrations of dissolved oxygen in water from domestic wells sampled for this study. 


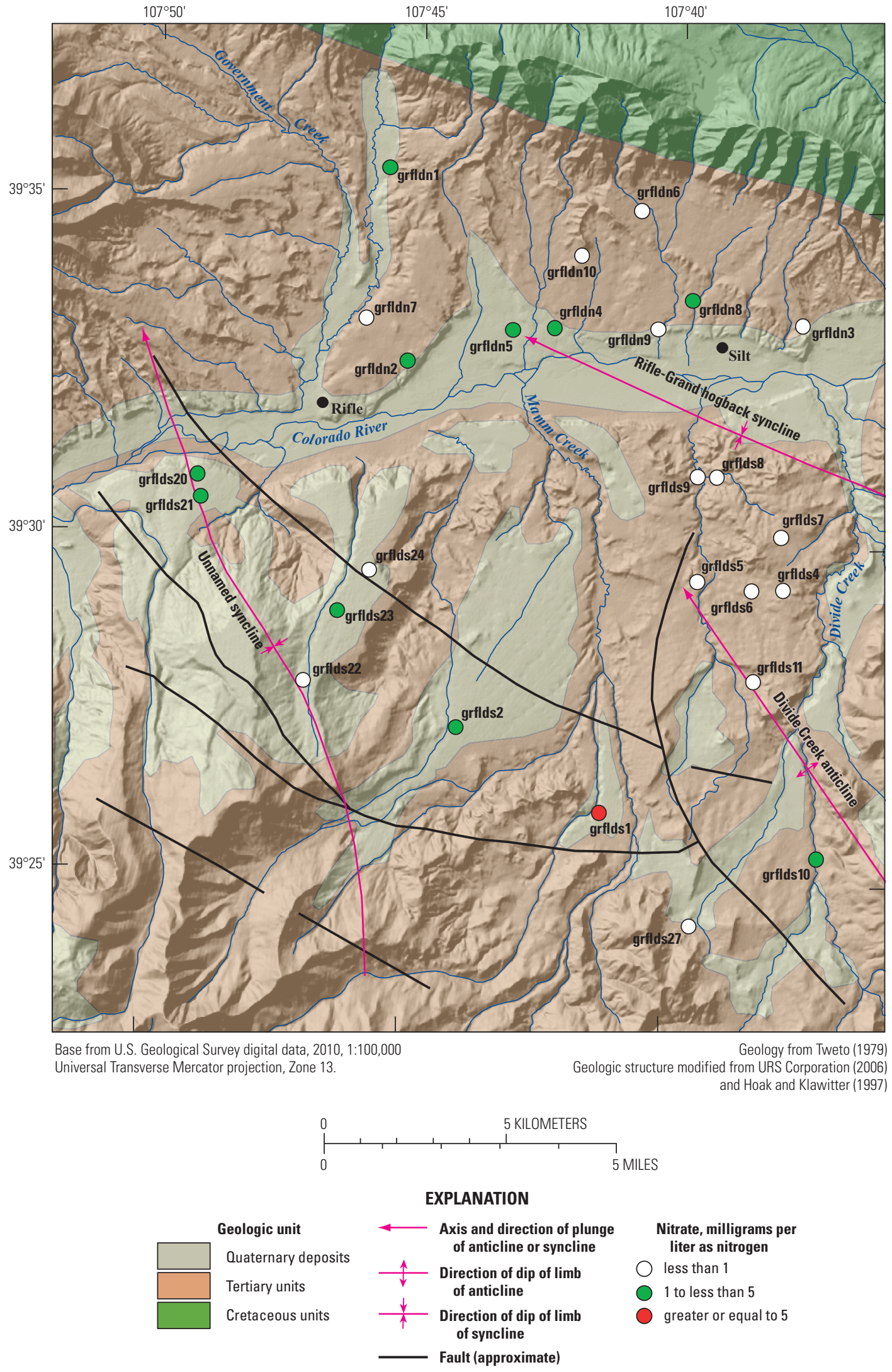

Figure 5. Concentrations of nitrate in water from domestic wells sampled for this study. 


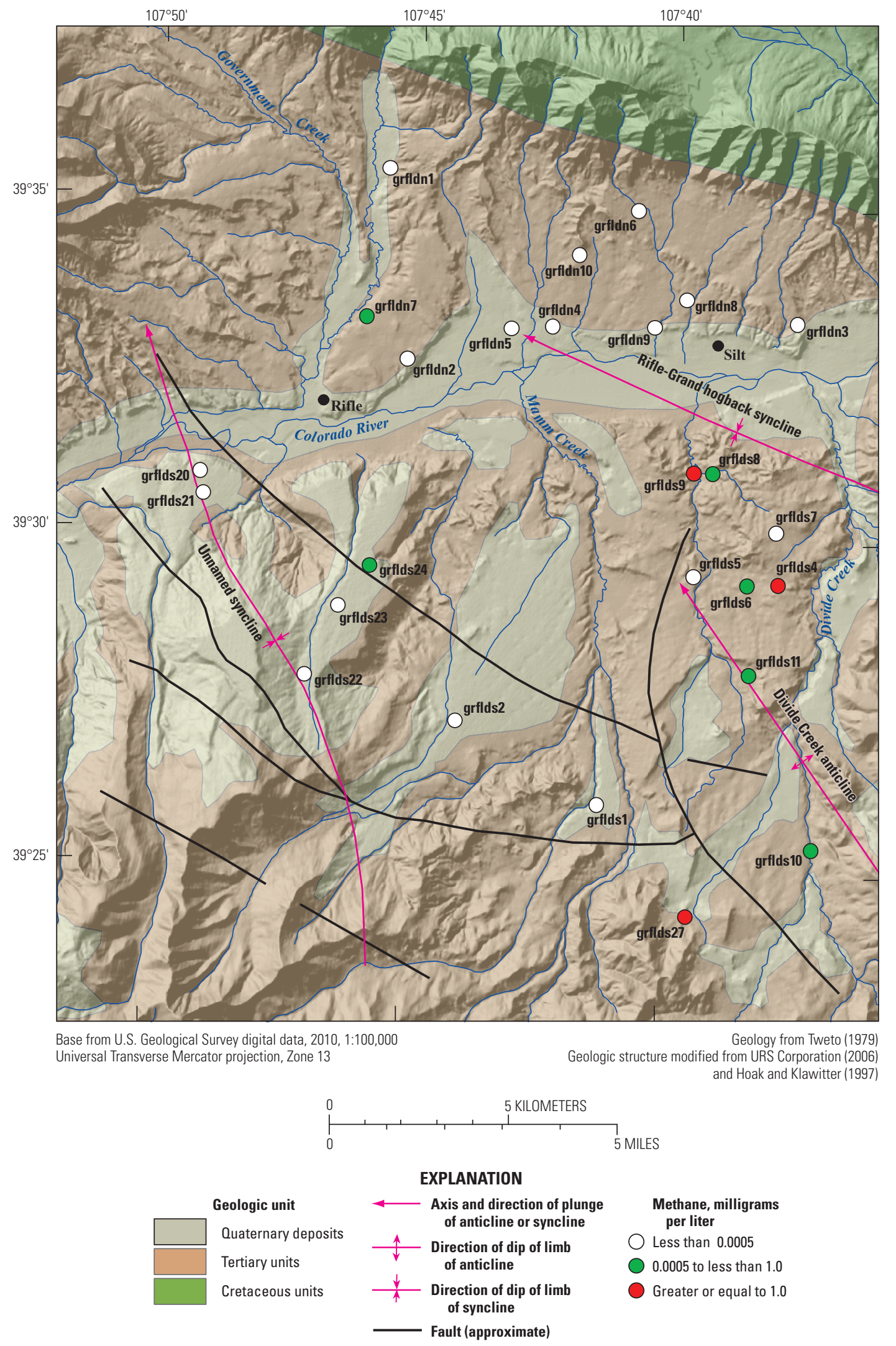

Figure 6. Concentrations of methane in water from domestic wells sampled for this study. 


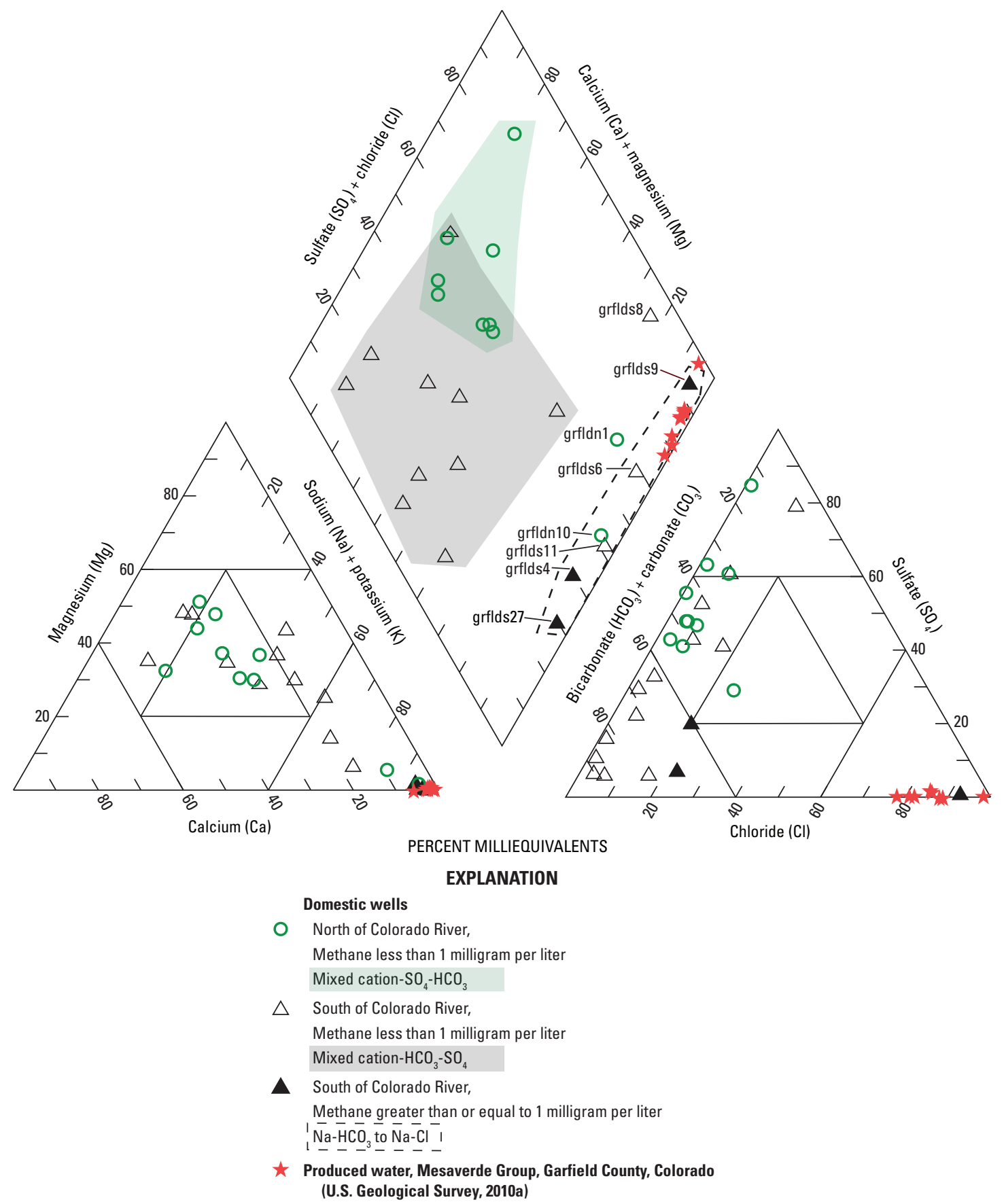

Figure 7. Major-ion chemistry of water from domestic wells sampled for this study, and major-ion chemistry of produced water from the Mesaverde Group.

\section{Groundwater Mixing}

Mixing groundwater from different sources could have important implications for the quality of groundwater in the Wasatch Formation. For example, when young, nitratecontaminated groundwater is mixed with old, nitrate-free groundwater or when young, dilute groundwater is mixed with old, saline groundwater or old, methane-enriched groundwater the quality of the resulting mixture could be better or worse than the end-member waters. Sorting out mixing processes that could involve water, ions, and gases requires multiple tracers because those constituents may not all be derived from the same sources. This section of the report examines mixing processes in the Wasatch Formation using stable isotopes of water $\left(\delta^{2} \mathrm{H}\left[\mathrm{H}_{2} \mathrm{O}\right]\right.$ and $\left.\delta^{18} \mathrm{O}\left[\mathrm{H}_{2} \mathrm{O}\right]\right)$, groundwater apparent ages, and chloride/bromide mass ratios. 


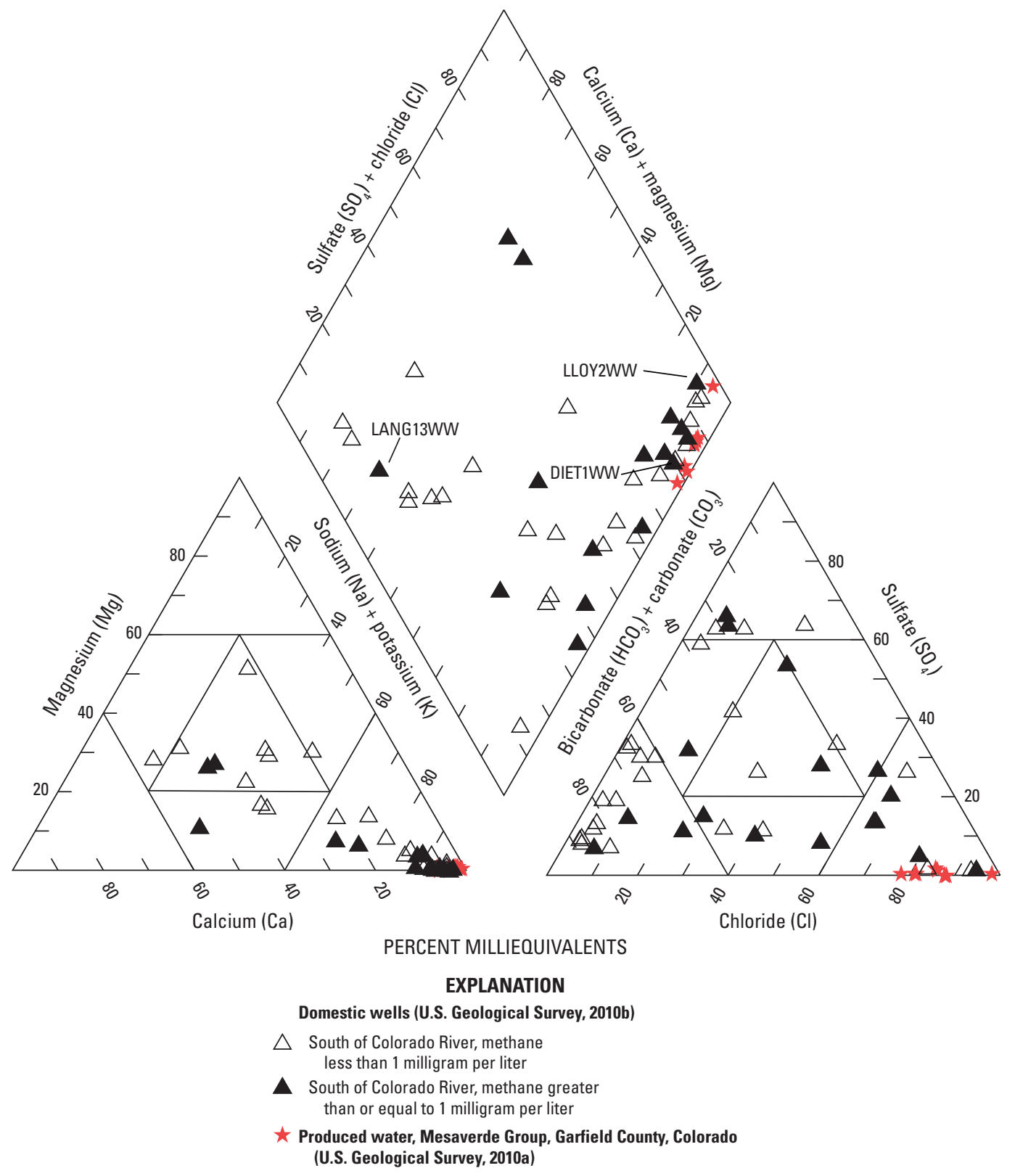

Figure 8. Major-ion chemistry of water from previously sampled domestic wells in the study area, and major-ion chemistry of produced water from the Mesaverde Group.

\section{Stable Isotopes of Water}

$\delta^{2} \mathrm{H}\left[\mathrm{H}_{2} \mathrm{O}\right]$ and $\delta^{18} \mathrm{O}\left[\mathrm{H}_{2} \mathrm{O}\right]$ values for samples collected for this study plotted near the Global Meteoric Water Line (Craig, 1961), indicating the water was derived from precipitation (fig. 9A). The samples plotted between the isotopic values for snow from Grand Mesa (located about $60 \mathrm{~km}$ southwest of the study area) and water from the Mesaverde Group. All but two of the samples (from grflds4, grflds9) plotted near the snow values, although shifted toward slightly more positive values, indicating they probably were derived from lower elevation precipitation than what was represented by the Grand Mesa snow samples. The Grand Mesa snow samples were collected at an elevation of
$3,230 \mathrm{~m}$, whereas the land-surface elevations of the sampled wells ranged from 1,672 to $2,155 \mathrm{~m}$ (table 1). The samples also could have contained small fractions of water from the Mesaverde Group, but that is difficult to determine from the isotopic values alone. The samples from grflds 4 and grflds 9 appeared to contain much larger fractions of water from the Mesaverde Group than the other samples (fig. 9A). All the water from grflds9 could have been from the Mesaverde Group on the basis of the $\delta^{2} \mathrm{H}\left[\mathrm{H}_{2} \mathrm{O}\right]$ and $\delta^{18} \mathrm{O}\left[\mathrm{H}_{2} \mathrm{O}\right]$ values and major-ion data (fig. 7).

A similar pattern in the water isotopic values was observed for samples collected from domestic wells during previous studies (fig. 9B). All but two of those samples (LLOY2WW, SCHW1WW) consisted mostly of snowmelt 
recharge. LLOY2WW and SCHW1WW apparently contained relatively large fractions of water from the Mesaverde Group. Previously collected major-ion data for LLOY2WW also indicated a similar composition to that of water from the Mesaverde Group (fig. 8). All four wells in figure 9 that contained relatively large fractions of water from the Mesaverde Group were located south of Silt in the zone that had groundwater with low concentrations of dissolved oxygen and nitrate and high concentrations of methane (figs. 4-6).

\section{Apparent Groundwater Ages}

All but two of the dated water samples collected for this study contained a component of young (less than 50 years) groundwater on the basis of tritium, chlorofluorocarbon, and sulfur hexafluoride data (table 1). Two samples (from grflds9 and grflds24) consisted entirely of old groundwater (greater than 50 years), 3 samples were mixtures of old and young groundwater (from grflds8, grflds22, and grflds23), and 12 samples consisted entirely of young groundwater (table 1). Fractions of old and young groundwater in the samples were estimated from tracertracer plots like the one shown in figure 10. Samples consisting
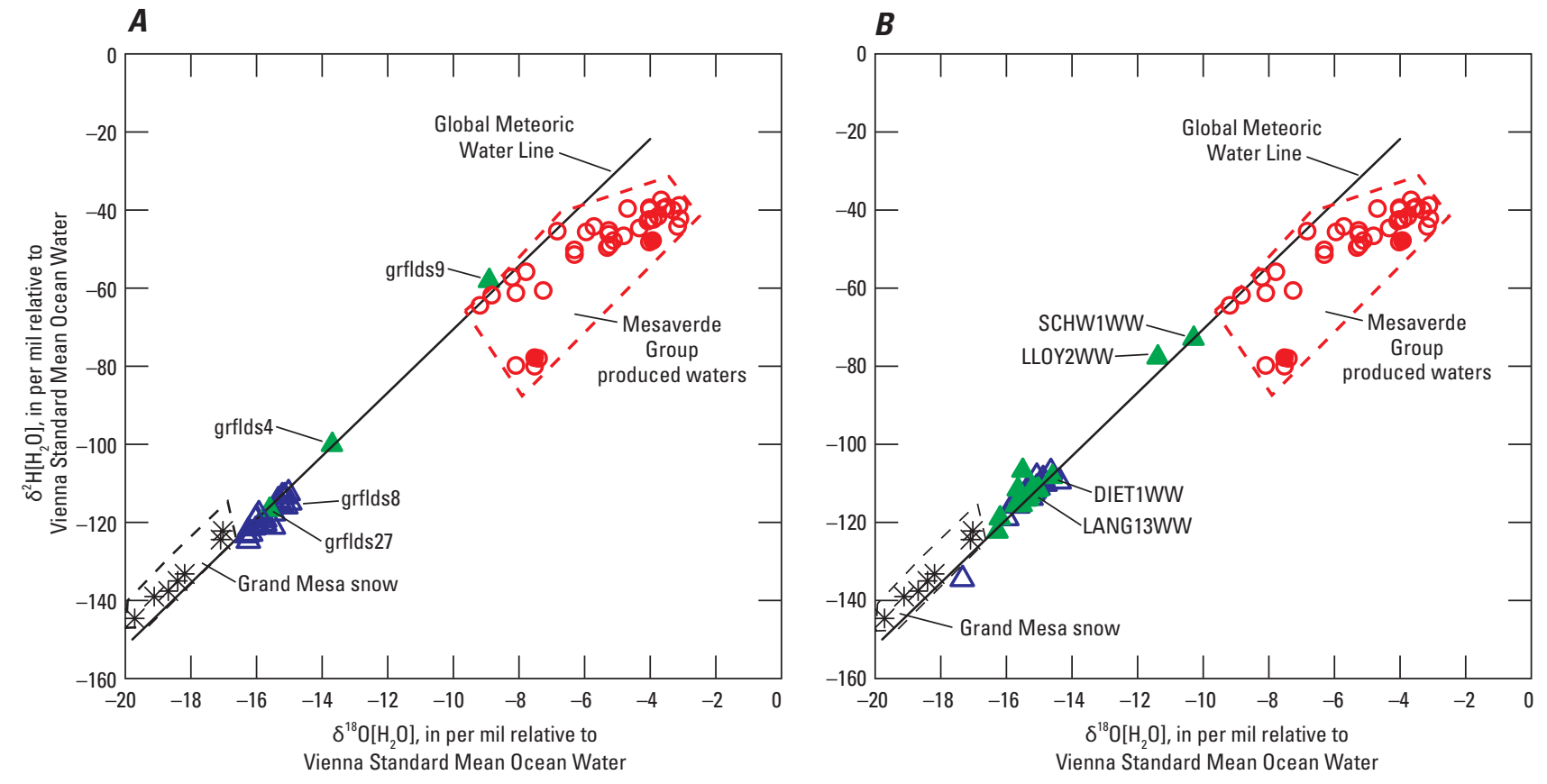

\section{EXPLANATION}

Domestic wells, $(A)$ this study and $(B)$ previous studies (U.S. Geological Survey, 2010b)

$\triangle \quad$ Less than 1 milligram per liter methane

$\Delta$ Greater than or equal to 1 milligram per liter methane Mesaverde Group produced waters

Samples from southwest Wyoming (U.S. Department of Energy, 2011)

- Samples from Garfield County, Colorado (U.S. Geological Survey, 2010b)

* Snow from Grand Mesa, Colorado (U.S. Geological Survey, unpublished data)

Figure 9. Stable isotopic compositions of water from domesitic wells $(A)$ sampled for this study and $(B)$ sampled during previous studies, compared to the stable isotopic compositions of snow from Grand Mesa, Colorado and produced waters from the Mesaverde Group. 


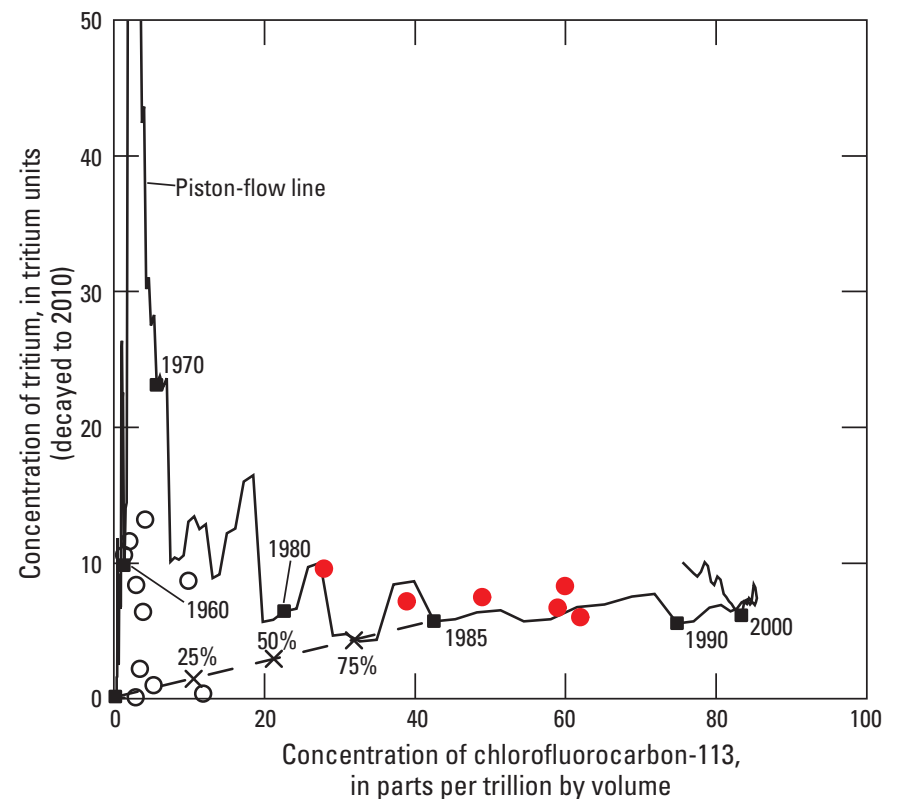

EXPLANATION

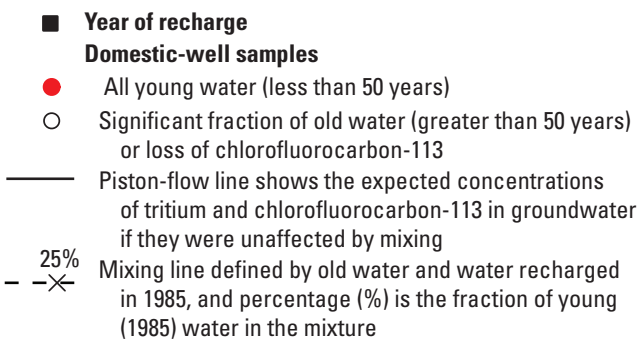

Figure 10. Concentrations of tritium and chlorofluorocarbon-113 in water from domestic wells sampled for this study.

The apparent ages of the young fraction of groundwater ranged from 20 to 39 years on the basis of tritium, chlorofluorocarbon, and sulfur hexafluoride data (table 1), and generally exhibited a positive relation with depth of the well screen below the water table (fig. 11), although the pattern contained considerable scatter. The two samples containing the oldest water (from grflds9 and grflds24) were among the deepest samples collected for this study. The age-depth patterns in figure 11 correspond to apparent vertical groundwater velocities on the order of 75 to 2,000 millimeters per year ( $\mathrm{mm} / \mathrm{yr}$ ), or recharge rates on the order of 15 to $400 \mathrm{~mm} / \mathrm{yr}$, assuming an aquifer porosity of 20 percent. Such variability in recharge could be expected in the study area because of its diverse land use and topographic settings. Higher recharge might occur in the vicinity of ponds, irrigation ditches, or intermittent stream channels compared to natural settings or interchannel areas. Higher recharge also might be expected at higher elevations as annual precipitation is generally greater there than at lower elevations. Aquifer zones with high recharge and relatively large nitrogen inputs at the land surface could be particularly vulnerable to nitrate contamination if the groundwater is oxic. The age of the younger fraction in a mixture of two young waters cannot be resolved with existing groundwater-age tracers. Therefore, the possibility exists that the young fractions themselves were mixtures containing some groundwater that was even younger than what is reported here. Generally, the effects of mixing on groundwater ages are reduced as the length of the screened interval of the sampled well decreases.

Apparent ages based on the tritium and helium-3 data were noticeably younger than the ages based on chlorofluorocarbon and sulfur hexafluoride data (table 1 and fig. 11). This could result from incomplete confinement of tritiogenic helium-3 in the aquifer, as discussed in the Groundwater Age section. For example, four of the samples dated with the tritium/helium-3 method (from grfldn9, grflds 1, grflds2, and grflds10) also were dated with the chlorofluorocarbon method. The median tritium/ helium-3 apparent age for those four samples was 6 years and the median chlorofluorocarbon apparent age was 26 years, supporting the notion that incomplete confinement of tritiogenic helium-3 biased the tritium/helium-3 ages young. Thus, the tritium/helium-3 apparent ages are considered minimum ages.

\section{Chloride/Bromide Mass Ratios}

Chloride/bromide mass ratios can provide information on fractions of water and chloride contributed to the samples from different sources. Potential sources examined here included young, dilute groundwater recharge, water from the Mesaverde Group, and leachate from sewage and/or animal-waste sources
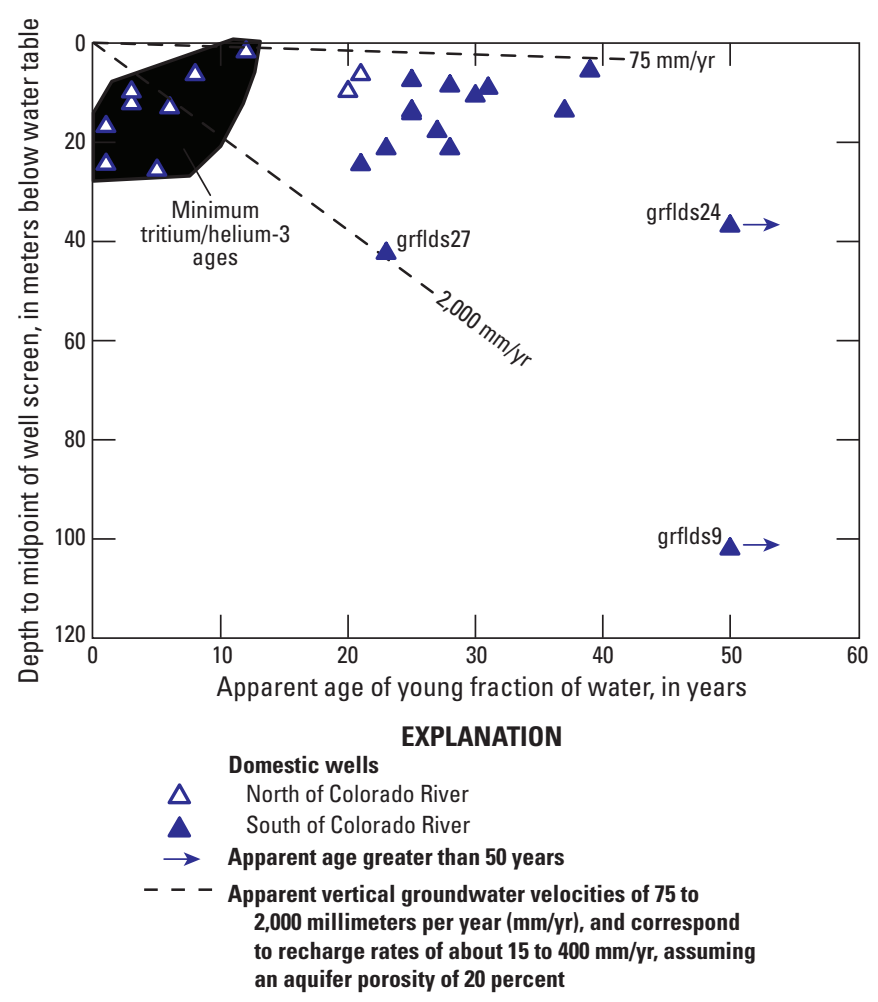

Figure 11. Apparent ages of the young fraction of water from domestic wells sampled for this study, based on tritium, chlorofluorocarbon, and/or sulfur hexafluoride measurements, except for the samples that plot in the field labeled "minimum tritium/helium-3 ages," whose ages were based on tritium and helium-3 measurements and may be biased young because of incomplete confinement of tritiogenic helium-3. 

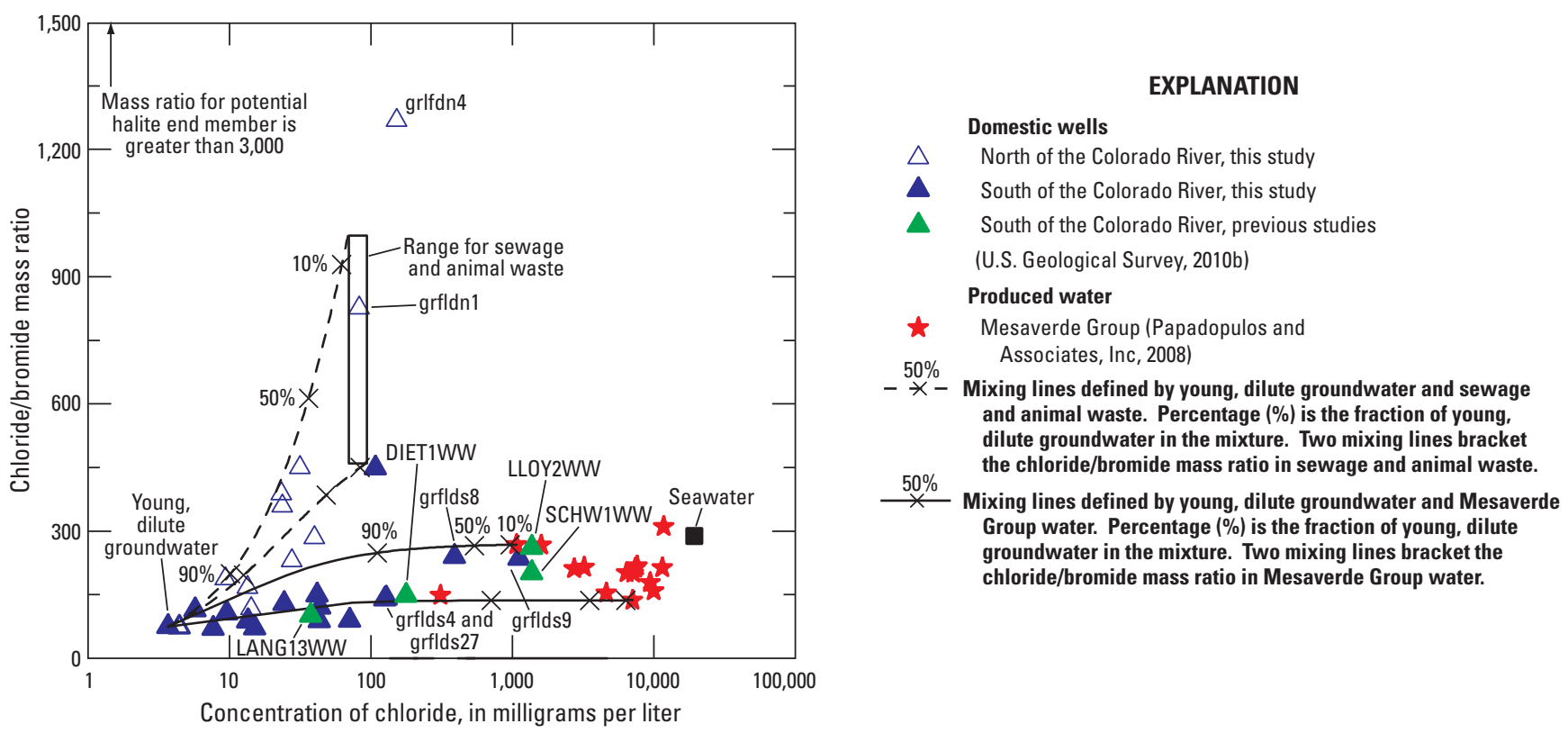

Figure 12. Chloride/bromide mass ratios in water from domestic wells sampled for this study and during previous studies. Ratios for seawater, halite, and sewage and animal waste are from Mullaney and others (2009).

(fig. 12). The most likely sources of sewage and animal waste in the vicinity of the sampled wells were septic systems and livestock/pets, respectively. Halite may have been an additional source of chloride in at least one of the samples, but halite was not used in the source analysis.

The source analysis examined two scenarios: mixing between (1) young, dilute groundwater and sewage and/or animal waste and (2) young, dilute groundwater and water from the Mesaverde Group. Two mixing lines were used to bracket the range of chloride/bromide ratios in the end-member waters (fig. 12). The fraction of water contributed to the mixture by each end member was calculated according to equations 5 and 6 :

$$
\begin{gathered}
\mathrm{Cl}_{\mathrm{s}}=\left(\mathrm{Cl}_{\mathrm{EM} 1}\right)(\mathrm{f})+\left(\mathrm{Cl}_{\mathrm{EM} 2}\right)(1-\mathrm{f}) \\
(\mathrm{Cl} / \mathrm{Br})_{\mathrm{s}}=\mathrm{Cl}_{\mathrm{s}} /\left[\left(\mathrm{Br}_{\mathrm{EM} 1}\right)(\mathrm{f})+\left(\mathrm{Br}_{\mathrm{EM} 2}\right)(1-\mathrm{f})\right]
\end{gathered}
$$

where

$\mathrm{Cl}_{\mathrm{s}}$ is the chloride concentration in the sample, $\mathrm{Cl}_{\mathrm{EM} 1}$ and $\mathrm{Cl}_{\mathrm{EM} 2}$ are the chloride concentrations in end members 1 and 2, respectively,

$\mathrm{f}$ is the fraction of end member 1 in the mixture,

$(\mathrm{Cl} / \mathrm{Br})_{\mathrm{s}} \quad$ is the chloride/bromide ratio in the sample,

and

$\mathrm{Br}_{\mathrm{EM} 1}$ and $\mathrm{Br}_{\mathrm{EM} 2}$ are the bromide concentrations in end members 1 and 2, respectively.

The fraction of chloride contributed to the mixture by each end member was calculated according to equations 7 and 8 :

Chloride from end member $1=\left(\mathrm{Cl}_{\mathrm{EM}}\right)(\mathrm{f}) / \mathrm{Cl}_{\mathrm{s}}$

Chloride from end member $2=\left(\mathrm{Cl}_{\mathrm{EM} 2}\right)(1-\mathrm{f}) / \mathrm{Cl}_{\mathrm{s}}$

Most of the samples consisted of more than 90 percent young, dilute groundwater. But relatively large contributions of water and chloride from sewage and/or animal-waste sources were apparent in some samples collected north of the Colorado River and large contributions of water and chloride from the Mesaverde Group were apparent in some samples collected south of the river (fig. 12). Some samples may have contained water and chloride from more than two sources.

Samples from grflds9 (this study) and LLOY2WW and SCHW1WW (U.S. Geological Survey, 2010b) may have derived more than 90 percent of their water and chloride from the Mesaverde Group, based on the mixing scenarios shown in figure 12, whereas the sample from grfldn 1 may have derived more than 90 percent of its water and chloride from sewage and/or animal-waste sources. Some samples (from grflds4, grflds27, DIET1WW, and LANG13WW) appeared to derive a large fraction of their water from dilute recharge but only a small fraction of their chloride content. The samples from grflds 4 and grflds27, for example, derived about 98 percent of their water and only 3 percent of their chloride from dilute recharge, based on the mixing scenarios illustrated in figure 12. The sample from grflds 8 derived about 64 percent of its water and less than 1 percent of its chloride from young, dilute recharge. The young fraction of water in grflds 8 was estimated to be about 50 percent on the basis of age tracers (table 1). These results indicate the Mesaverde Group was an important source of chloride (and possibly other constituents as well) in several of the samples collected south of the river, even when the actual fraction of water from the Mesaverde Group in the sample was small. This is because of the large effect that elevated chloride concentrations in water from the Mesaverde Group have on the mixing calculations. These interpreted mixing fractions could vary if the actual end-member compositions differed from what is shown in figure 12 , or if other end members not identified here contributed water and chloride to the samples. 


\section{Summary of Mixing Results}

The water-isotopic, age-tracer, and chloride/bromide data indicate most of the sampled groundwater consisted of snowmelt recharge with apparent ages less than 50 years old. Some samples also contained fractions of water from sewage and/or animalwaste sources, and this was most apparent north of the Colorado River. A few samples collected south of the river contained large fractions of water from the Mesaverde Group. The samples with large fractions of water from the Mesaverde Group also contained a component of old (greater than 50 years) water based on the age tracers, but not all the old groundwater contained water from the Mesaverde Group. The Mesaverde Group appeared to be an important source of chloride in several of the samples collected south of the river, even when the actual fraction of water from the Mesaverde Group in the sample was small.

\section{Sources and Sinks of Nitrate in Groundwater}

All but two of the samples contained at least a fraction of young water, indicating the wells from which those samples were collected could have been vulnerable to nitrate contamination from surface sources. Figure $13 A$ shows samples with the highest measured nitrate concentrations also contained at least a fraction of young groundwater. The most likely sources of high-nitrate groundwater in the study area included septic systems, animal manure, and fertilizer applied to lawns and crops. Several samples appeared to contain a component of water from sewage (septicsystem effluent) or animal-waste sources on the basis of chloride/ bromide mass ratios (fig. 12), and one of them (from grfldn1) had the second highest measured nitrate concentration (fig. 13A). A more precise characterization of nitrate sources was beyond the scope of this project, but well established geochemical and isotopic tracer techniques are available for such purposes (Böhlke and others, 2002; McMahon and others, 2008).

Samples with some of the lowest measured nitrate concentrations were anoxic or contained old groundwater. The low nitrate concentrations could reflect denitrification processes in the aquifer or low nitrate concentrations in the water at the time it recharged the aquifer, or both. The measured nitrate concentrations in anoxic samples where corrected for denitrification affects in the aquifer by adding back excess nitrogen gas from denitrification, thus providing an estimate of the nitrate concentration in the water at the time it recharged the aquifer. Several of the samples with low dissolved-oxygen concentrations, such as the samples from grflds6 and grflds8, had substantially larger nitrate concentrations at the time of recharge than at the time of sampling (table 1, figs. 13A and 13C). The nitrate concentration in water from grflds6 at the time of recharge was about $14 \mathrm{mg} / \mathrm{L}$ as $\mathrm{N}$, which would have exceeded the federal drinking-water standard for nitrate (fig. 13C) (U.S. Environmental Protection Agency, 2010), but denitrification in the aquifer removed 99 percent of that nitrate during its 31-year residence time in the aquifer (table 1). These data indicate denitrification was an important sink for nitrate in parts of the aquifer containing groundwater with low concentrations of dissolved oxygen, particularly in the zone located south of Silt (figs. 4 and 5). In contrast to the samples containing young groundwater, the one sample (from grflds24) that contained 100 percent old groundwater and had sufficient gas data to make denitrification corrections was recharged with a nitrate concentration of about $1.6 \mathrm{mg} / \mathrm{L}$ as $\mathrm{N}$ (fig. 13), indicating nitrate concentrations in that water were low at the time it recharged the aquifer prior to the 1950s.

\section{Sources and Sinks of Methane in Groundwater}

Sources and sinks of methane in water from the Wasatch Formation were examined using hydrocarbon and noble-gas tracers. Hydrocarbon molecular and isotopic tracers were used to determine whether the high methane concentrations in some samples were biogenic or thermogenic in origin and whether oxidation processes in the aquifer could be a sink for methane. Biogenic methane is derived from the microbial degradation of organic matter by methanogenic bacteria in the subsurface. Thermogenic methane is derived from the abiotic degradation of organic matter at high temperatures and pressures when it is deeply buried in the subsurface. Helium concentrations and isotopes were used to examine whether the high methane concentrations in some samples could have formed within or external to the sampled intervals of the Wasatch Formation and they were used to provide qualitative constraints on the age of groundwater containing the highest methane concentrations.

\section{Hydrocarbon Molecular and Isotopic Compositions}

Hydrocarbon molecular and isotopic compositions have been used in several studies to determine sources of methane in groundwater (Bernard and others, 1978; Barker and Fritz, 1981; Whiticar, 1999; URS Corporation, 2006; Papadopulos \& Associates, Inc., 2008). Data from this study indicate methane in two of the three samples with high concentrations (from grflds9 and grflds27) was biogenic in origin, whereas methane in natural-gas samples from the Piceance Basin was thermogenic in origin (fig. 14A) (Johnson and Rice, 1990). Data for the third sample with a high methane concentration (from grflds4) plotted between the fields for thermogenic and biogenic gases in figure $14 A$, which could be interpreted as a mixture of gases from both sources. As discussed previously, water from grflds 4 was a mixture of young and old waters. But water from grflds 4 also contained dissolved oxygen (table 1), presumably from the young fraction of water in the sample, so the possibility that methane oxidation affected the composition of that sample cannot be ruled out. Methane oxidation would have the effect of shifting the molecular and isotopic compositions of the sample away from the biogenic field and toward 
A

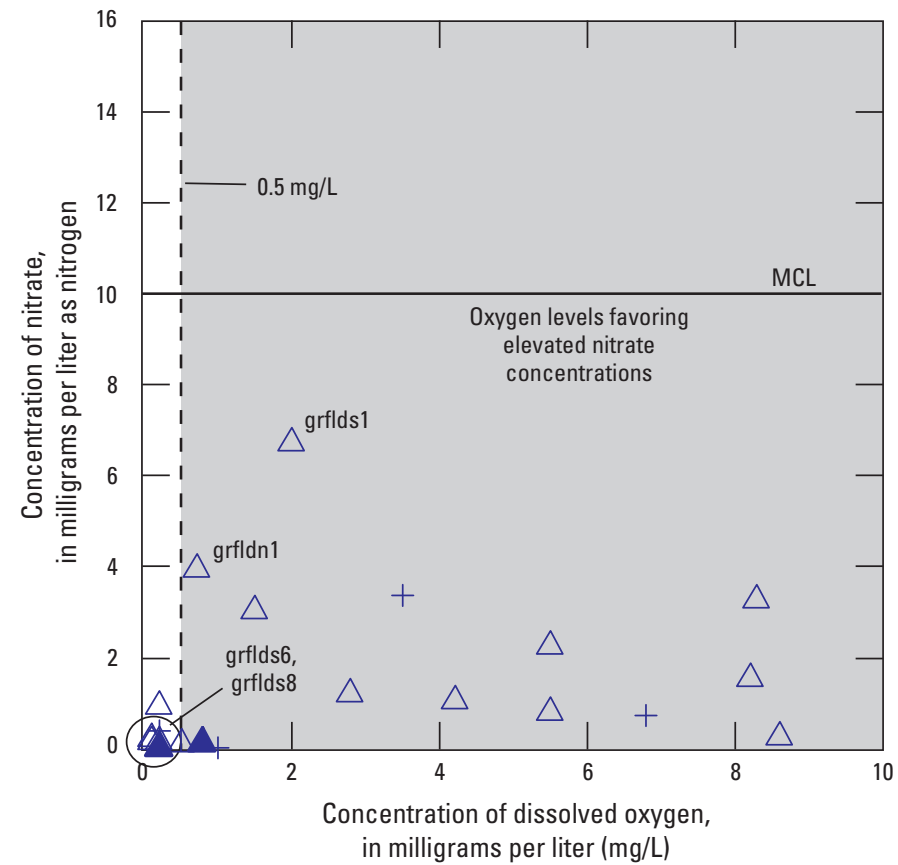

C

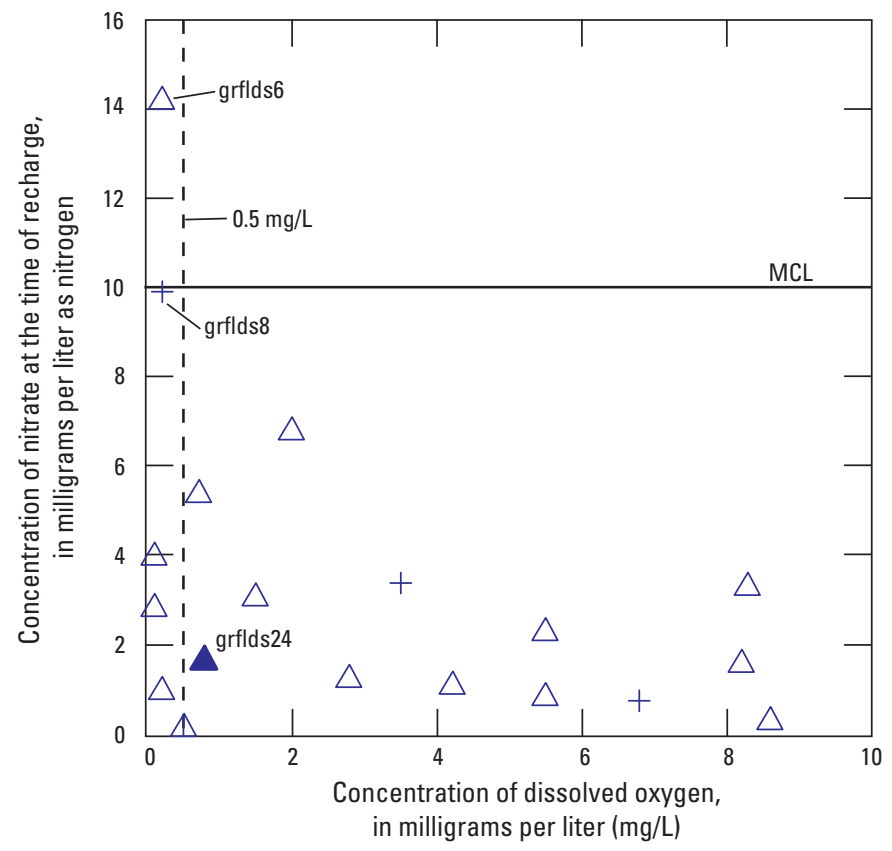

the thermogenic field of figure $14 A$ (Whiticar, 1999). Based on the dissolved-oxygen data and position of the sample from grflds 4 in figure $14 \mathrm{~A}$ relative to the likely mixing scenarios, methane in that sample was considered to be biogenic in origin but affected by oxidation processes.

Methane oxidation also may have affected hydrocarbon molecular and isotopic compositions in samples collected during previous studies (fig. 14B). The median concentration of dissolved oxygen in samples with methane/(ethane + propane) ratios larger than 200 (biogenic methane) was $1.1 \mathrm{mg} / \mathrm{L}$ and it was $2.7 \mathrm{mg} / \mathrm{L}$ in samples with ratios less than 50 (thermogenic methane). In other words, the most oxic groundwater samples
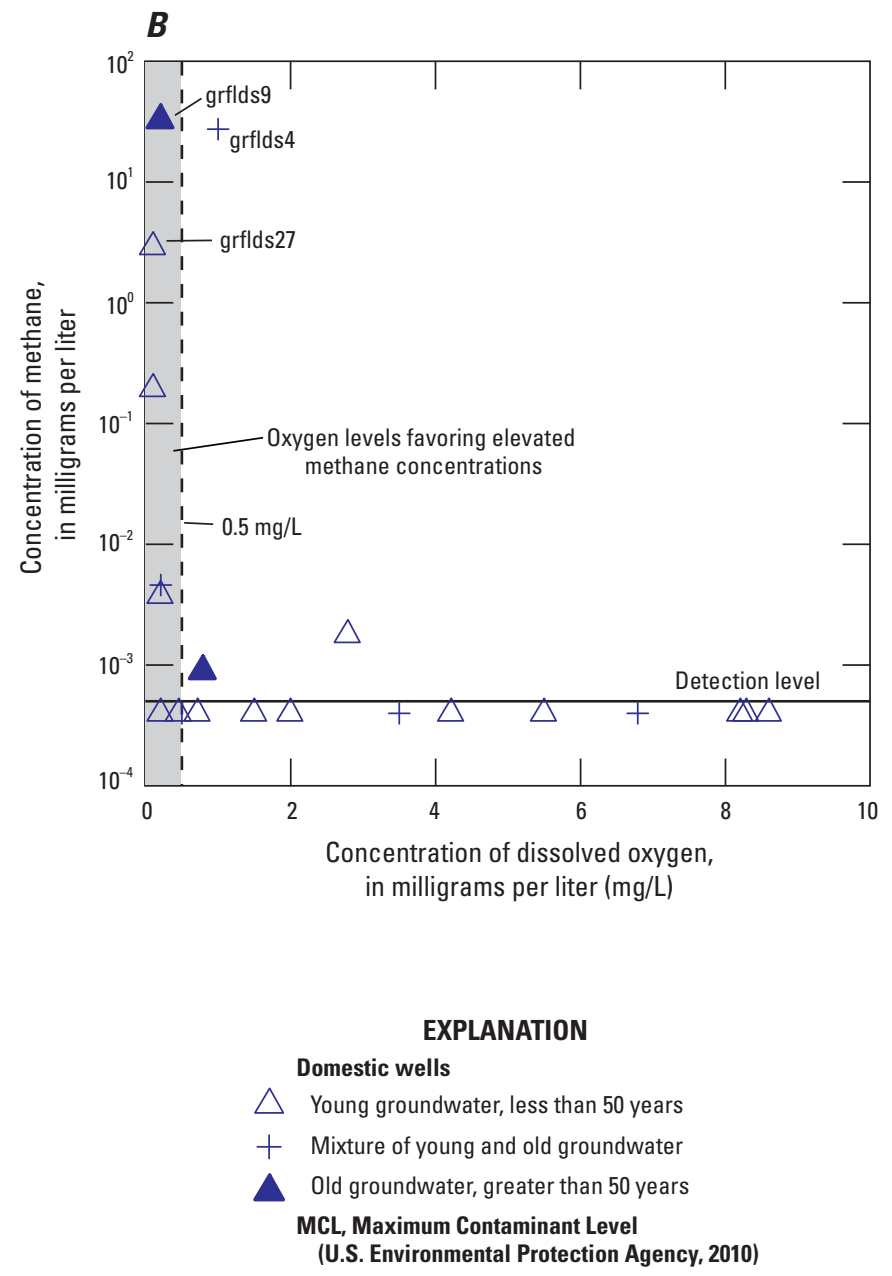

Figure 13. Measured concentrations of $(A)$ nitrate and $(B)$ methane in water from domestic wells sampled for this study, and $(C)$ concentrations of nitrate in the samples at the time they were recharged (measured nitrate concentration + concentration of excess nitrogen gas from denitrification), in relation to concentrations of dissolved oxygen. The shaded regions in $(A)$ and $(B)$ indicate ranges of dissolved oxygen concentrations in which nitrate and methane concentrations were highest, respectively.

plotted in the thermogenic field of fig. 14B, indicating methane oxidation could have altered the composition of some of those samples. Methane oxidation also could be coupled with sulfate reduction in groundwater with low concentrations of dissolved oxygen (Van Stempvoort and others, 2005), but data needed to evaluate that process were not collected as part of this study. Despite the probable role of aerobic oxidation as a methane sink in the aquifer, several of the samples, such as DIET1WW and LANG13WW, were both anoxic and had molecular and isotopic compositions indicative of a thermogenic methane source (fig. 14B). So there is evidence for the occurrence of thermogenic methane from the Mesaverde Group, or some other deep 
$\boldsymbol{A}$

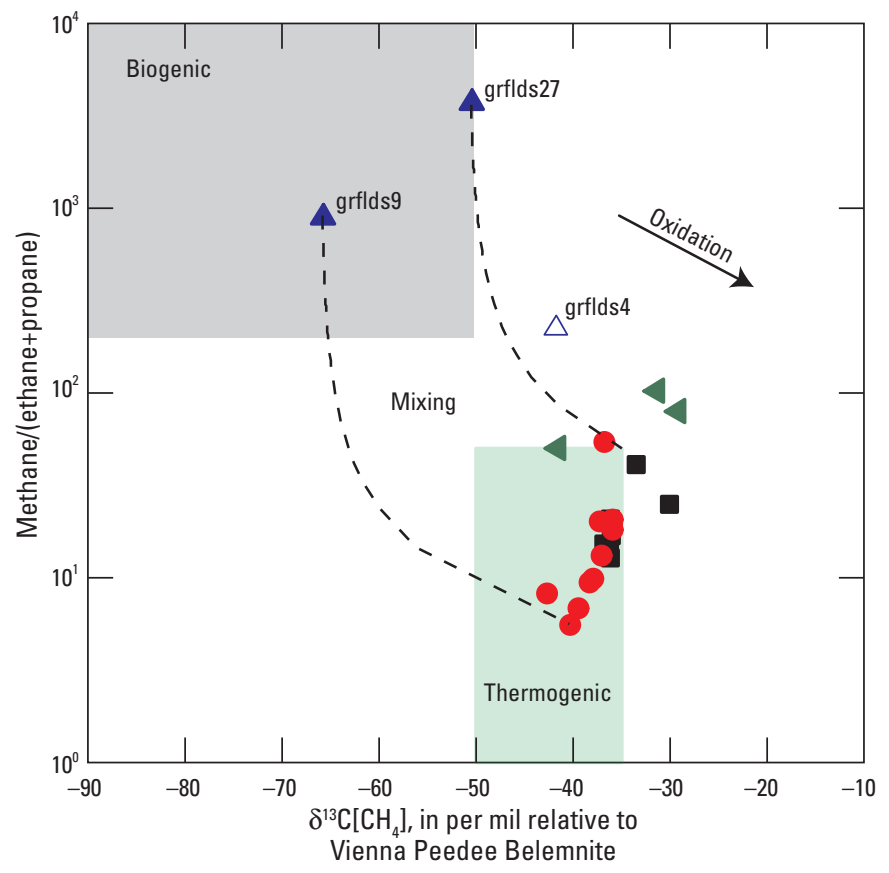

B

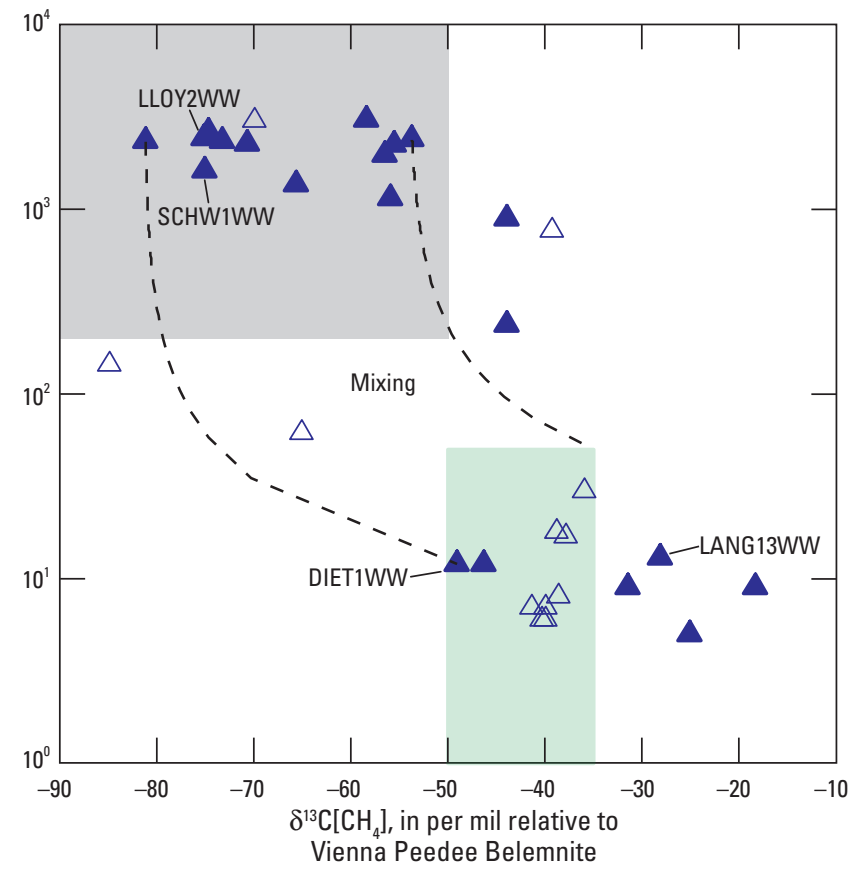

EXPLANATION

Domestic wells, $(A)$ this study and $(B)$ previous studies (U.S. Geological Survey, 2010b)

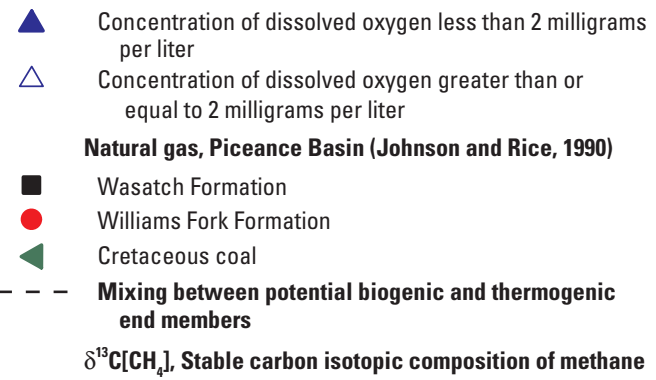

Figure 14. Molecular and isotopic composition of short-chain hydrocarbons in water from domestic wells $(A)$ sampled for this study and $(B)$ sampled during previous studies. Biogenic and thermogenic fields modified from Bernard and others (1978) and Whiticar (1999).

source, in the Wasatch Formation. Like the wells sampled for this study that produced high-methane water, DIET1WW and LANG13WW were located in the zone of low dissolved-oxygen and high methane concentrations south of Silt. Even though the DIET1WW and LANG13WW samples appeared to contain thermogenic methane, the water-isotopic and chloride/bromide data indicate they contained relatively little water from the Mesaverde Group.

\section{Helium Concentrations and Isotopes}

Although the high concentrations of methane in some samples collected for this study appeared to be biogenic in origin that does not necessarily mean the methane was produced in the sampled intervals of the Wasatch Formation. The major-ion, waterisotopic, and chloride/bromide data show that samples containing high concentrations of biogenic methane, like the samples from grflds9, LLOY2WW, and SCHW1WW, also appeared to contain substantial fractions of Mesaverde water and ions. Noble-gas measurements indicate the zone of low dissolved-oxygen and high methane concentrations in which those wells were located (south of Silt) also was an area of high helium-4 concentrations, with concentrations up to $4,900 \times 10^{-8}$ cubic centimeters at standard temperature and pressure, per gram of water $\left(\mathrm{cm}^{3} \mathrm{STP} / \mathrm{g}\right)$ (table 1 and fig. 15). That helium-4 concentration is about 1,000 times higher than the concentration expected in water equilibrated with air at $10^{\circ} \mathrm{C}$ and $1,800 \mathrm{~m}$ elevation, indicating groundwater in that area contained a large component of helium-4 derived from subsurface (terrigenic) sources. Importantly, there appeared to be a positive relation between methane and helium- 4 concentrations (fig. 16A), implying helium-4 could be a useful tracer for understanding the geologic source of the high methane concentrations.

The primary terrigenic sources of helium-4 are upward fluxes from the mantle and decay of uranium and thorium in rocks and sediment of the earth's crust. If terrigenic helium-4 in the samples was from mantle sources then the co-occurrence of high concentrations of helium-4 and biogenic methane (fig. 16A) may just be coincidental because biogenic 


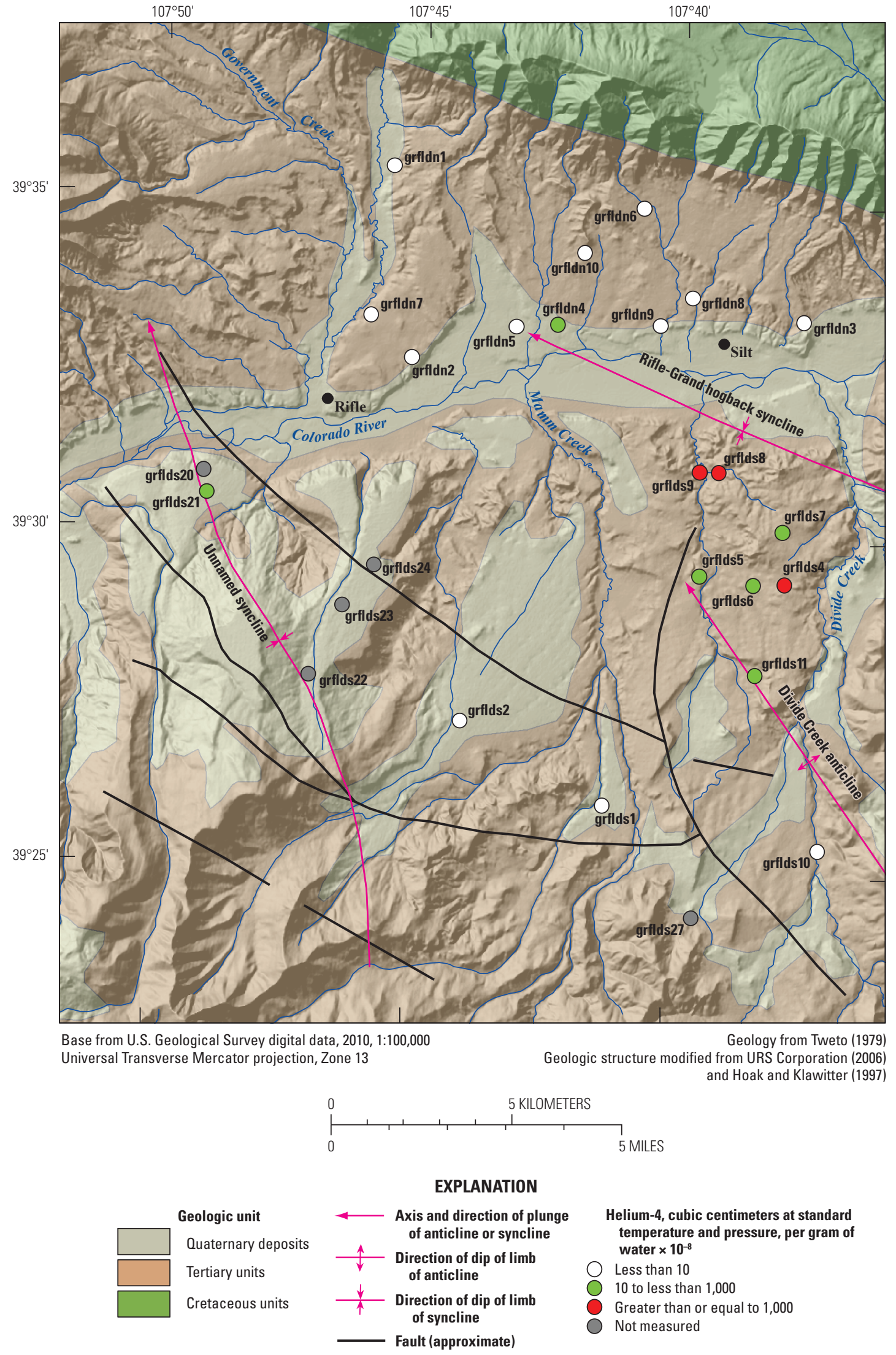

Figure 15. Concentrations of helium-4 in water from domestic wells sampled for this study. Geology from Tweto (1979). Geologic structure modified from URS Corporation (2006) and Hoak and Klawitter (1997). 

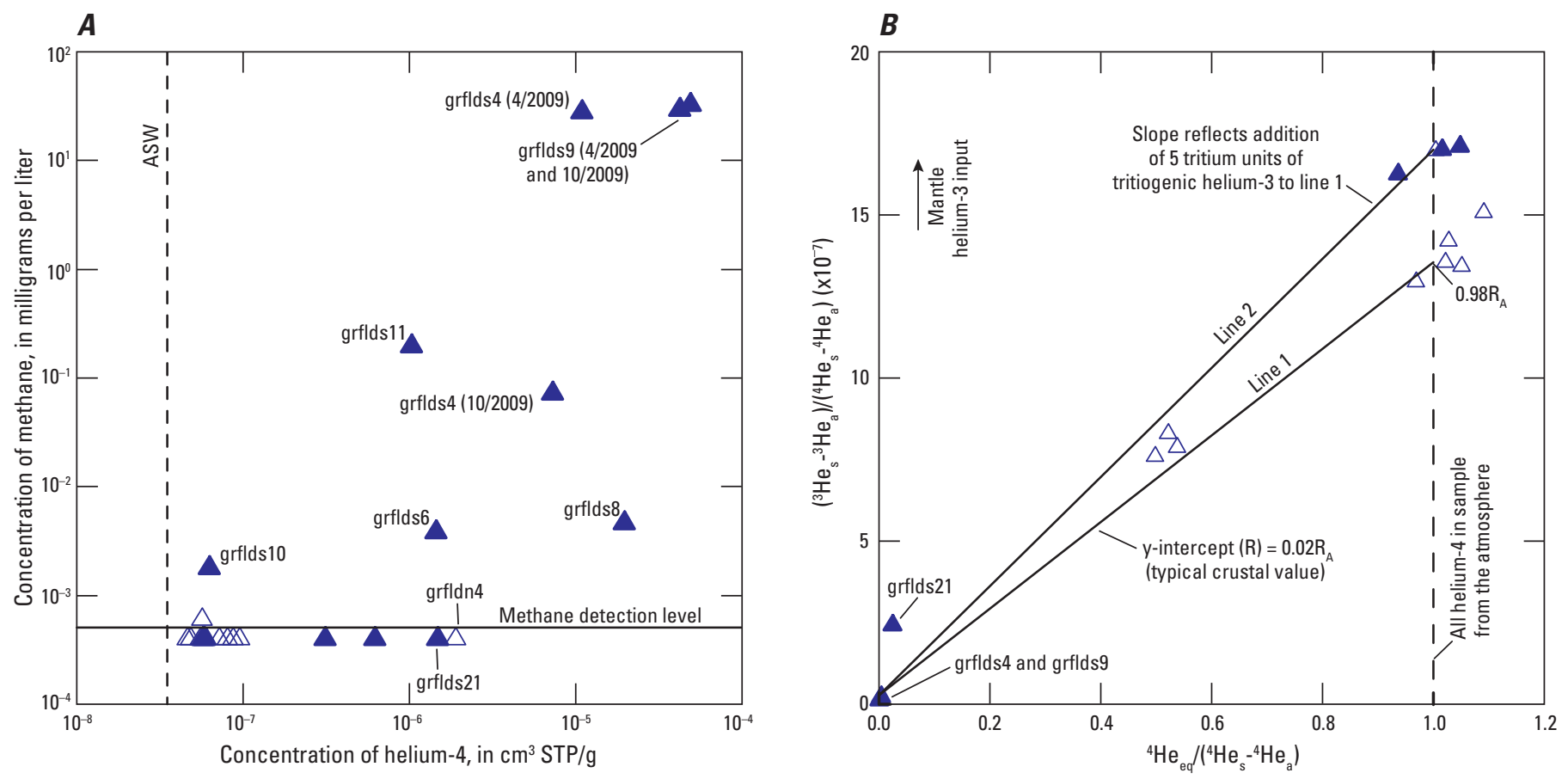

\section{EXPLANATION}

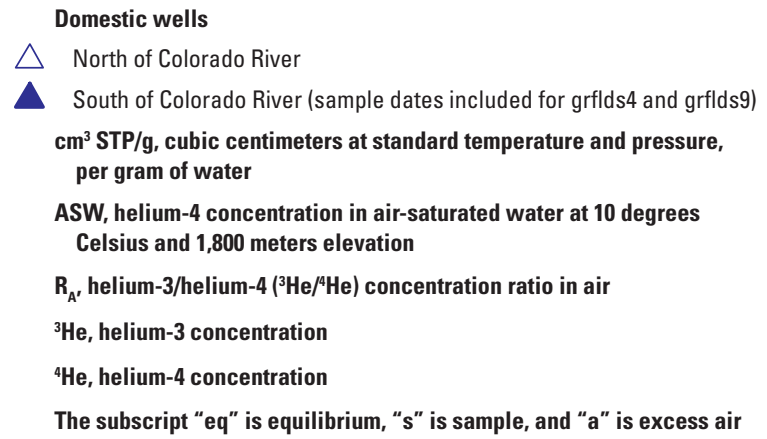

Figure 16. (A) Methane concentrations in relation to helium-4 concentrations in water from domestic wells sampled for this study and $(B)$ measured helium-3/helium- 4 ratios corrected for excess air in relation to the relative amount of helium- 4 derived from air-water equilibrium with respect to total helium- 4 in the sample, corrected for excess air.

methane is not likely to form under the high temperature and pressure conditions in the earth's mantle (Scott and others, 2004). Helium-3/helium-4 ratios can be used to differentiate mantle and crustal sources of ${ }^{4} \mathrm{He}$. Crustal sources of helium typically have helium-3/helium- 4 ratios about 0.02 times the ratio in air $\left(0.02 R_{\wedge}\right)$, whereas mantle helium typically has ratios that are about $7 \mathrm{R}_{\mathrm{A}}$ (Mamyrin and Tolstikhin, 1984; Ozima and Podosek, 1983). In figure 16B, helium-3/ helium-4 ratios were plotted in relation to the relative amount of helium-4 derived from air-water equilibrium with respect to total helium- 4 in the sample. An $\mathrm{x}$-axis value of 0 indicates essentially all the helium- 4 in the sample was from terrigenic sources. An x-axis value of 1 indicates all the helium- 4 was from the atmosphere. Most of the samples had $\mathrm{x}$-axis values near 1 , indicating a predominantly atmospheric source for the helium (samples with $\mathrm{x}$-axis values greater than 1 probably were affected by degassing at the time of recharge or during sampling). Of those samples, some had helium-3/helium-4 ratios equal to $0.98 \mathrm{R}_{\mathrm{A}}$, consistent with helium from waterair equilibration, and some had ratios greater than $0.98 \mathrm{R}_{\mathrm{A}}$. In the latter case, this is likely explained by contributions of tritiogenic helium-3 to those samples from tritium decay because all of them contained tritium (line 2 in fig. 16B). The data indicate essentially all the helium- 4 in the high-methane samples from grflds 4 and grflds 9 was from crustal sources ( $\mathrm{x}$-axis value near 0 and helium-3/helium- 4 ratio near $0.02 \mathrm{R}_{\mathrm{A}}$ $\left(0.009 \mathrm{R}_{\mathrm{A}}\right.$ to $\left.\left.0.017 \mathrm{R}_{\mathrm{A}}\right)\right)$. One sample, from grflds 21 , that had a large component of terrigenic helium- 4 (x-axis value less than 0.2 ) also had a helium-3/helium-4 ratio larger than $0.02 \mathrm{R}_{\mathrm{A}}$ $\left(0.174 R_{A}\right)$. That sample could contain a small component of mantle helium. In general, the data in figure $16 B$ indicate the primary terrigenic source of helium- 4 in the samples was the crust, with a helium-3/helium-4 ratio close to $0.02 \mathrm{R}_{\mathrm{A}}$. 
The three most likely sources of crustal helium- 4 are (1) helium-4 produced within the aquifer itself from the decay of uranium and thorium, (2) helium-4 produced at depths below the aquifer and then transported into the aquifer by diffusion or advection, and (3) helium-4 stored in aquifer minerals that is released from the surfaces of relatively freshly fractured or weathered rocks (Torgersen, 1980; Kulongoski and others, 2005). Helium-4 concentrations plotted in relation to depth of the well screen below the water table indicate most of the samples plotted within an envelope of helium- 4 concentration gradients ranging from about $1 \times 10^{-8}$ to $1 \times 10^{-7} \mathrm{~cm}^{3} \mathrm{STP} / \mathrm{g} \cdot \mathrm{m}$ (fig. 17). Most of those samples were recharged in the past 50 years (fig. 11), and they contained only very small fractions of water from the Mesaverde Group on the basis of water-isotopic and chloride/bromide data (figs. 9 and 12). The data are consistent with in-situ production of small amounts of helium-4 in the Wasatch Formation from uranium and thorium decay during the short residence time of those samples in the aquifer (crustal source 1). Samples from grflds 8 and grflds9, which had the highest helium-4 concentrations and largest fractions of water from the Mesaverde
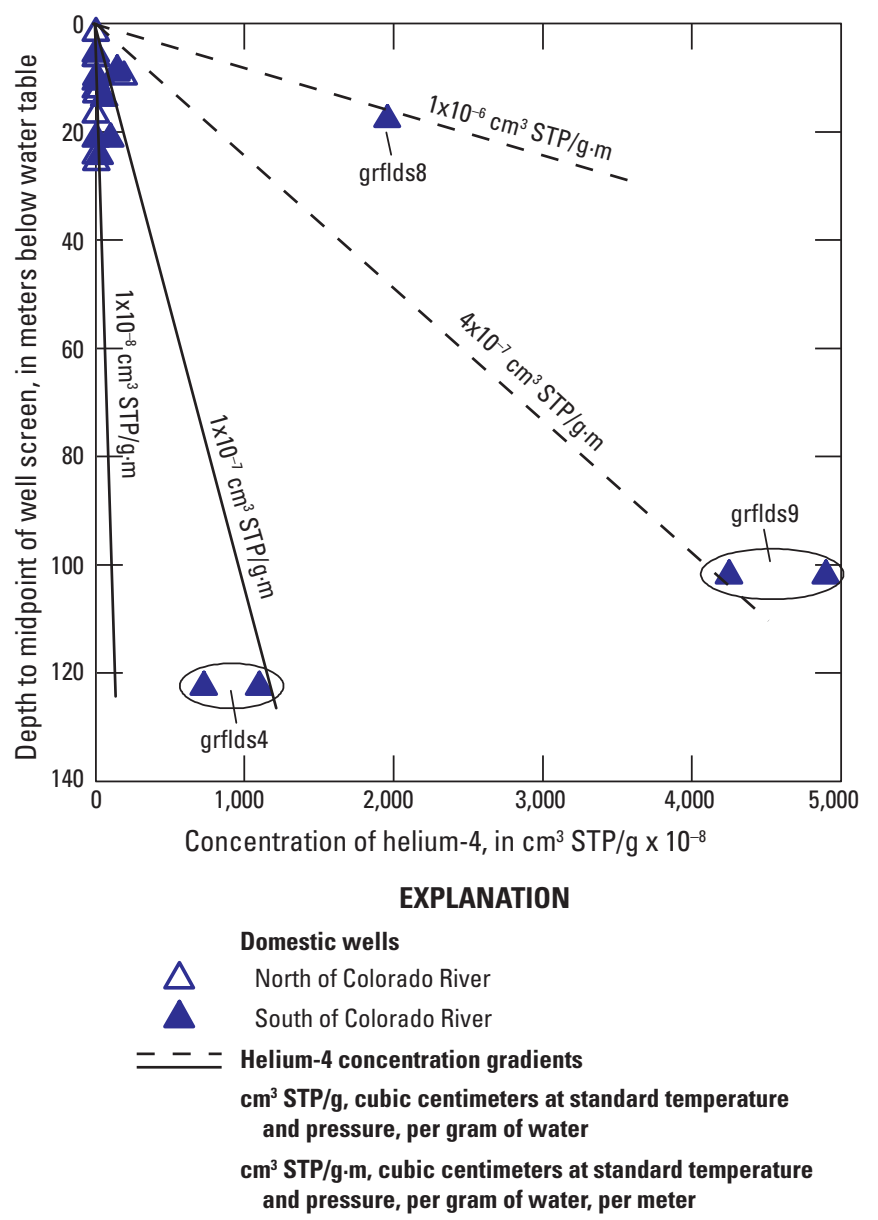

Figure 17. Concentrations of helium-4 in water from domestic wells sampled for this study in relation to depth below the water table to the midpoint of the well screen.
Group on the basis of chloride/bromide data (fig. 12), represented larger gradients ranging from about $4 \times 10^{-7}$ to $1 \times 10^{-6} \mathrm{~cm}^{3} \mathrm{STP} / \mathrm{g} \cdot \mathrm{m}$. The disparity in helium-4 gradients between the samples with small and large fractions of water from the Mesaverde Group could indicate high helium-4 in the latter group of samples was contained in much older groundwater, such as in the Mesaverde Group or some other relatively deep geologic unit, and subsequently transported into the Wasatch Formation (crustal source 2). The other possible source of high helium-4 in water from grflds8 and grflds9, release from relatively freshly fractured or weathered rocks in the aquifer (crustal source 3), cannot be ruled out but seems less likely because of the Mesaverde-like composition of those water samples.

Concentrations of crustal helium- 4 in the samples can be used to qualitatively constrain groundwater age in the flow system using the following equations (Andrews and Lee, 1979; Stute and others, 1992):

$$
\begin{aligned}
{ }^{4} H e_{\text {sol }} & =\rho_{s} \times \Lambda \times\left\{1.19 \times 10^{-13}[U]\right. \\
& \left.+2.88 \times 10^{-14}[T h]\right\} \times \frac{(1-n)}{n}
\end{aligned}
$$

and

$$
\text { age }=\frac{{ }^{4} H e_{\text {crustal }}}{\frac{J}{100 n z \rho_{w}}+{ }^{4} H e_{\text {sol }}}
$$

where

${ }^{4} H e_{\text {sol }}$ is the rate at which helium-4 enters solution from uranium and thorium decay, in cubic centimeters at standard temperature and pressure, per gram, per year $\left(\mathrm{cm}^{3} \mathrm{STP} / \mathrm{g} \cdot \mathrm{yr}\right)$;

$\rho_{s} \quad$ is rock bulk density, in grams per cubic centimeter $\left(\mathrm{g} / \mathrm{cm}^{3}\right)$;

$\Lambda$ is the fraction of helium-4 produced in the rock that is released into solution, unitless $(\Lambda$ is assumed to equal 1 for aquifers; Andrews and Lee, 1979; Torgersen and Clarke, 1985);

$[U]$ and $[T h]$ are uranium and thorium concentrations in the aquifer material, in parts per million ( $\mathrm{ppm}$ );

$n$ is porosity, unitless;

${ }^{4} \mathrm{He}$ crustal $\quad$ is the concentration of crustal helium- 4 in the sample, in cubic centimeters at standard temperature and pressure, per gram of water $\left(\mathrm{cm}^{3} \mathrm{STP} / \mathrm{g}\right)$;

$J \quad$ is the helium-4 flux across the base of the aquifer, in cubic centimeters at standard temperature and pressure, per square centimeter, per year $\left(\mathrm{cm}^{3} \mathrm{STP} / \mathrm{cm}^{2} \cdot \mathrm{yr}\right)$;

$z \quad$ is the distance from the well screen to the base of the aquifer, in meters;

and

$\rho_{w} \quad$ is the density of water (about $1 \mathrm{~g} / \mathrm{cm}^{3}$ ). 
For the age calculations summarized in table 2, it was assumed that $\rho_{\mathrm{s}}=2.65 \mathrm{~g} / \mathrm{cm}^{3},[\mathrm{U}]=2.2 \mathrm{ppm}$ and $[\mathrm{Th}]=9 \mathrm{ppm}$, and $\mathrm{n}=0.2$. Concentrations of uranium and thorium in the Wasatch outcrop area, derived from aerial gamma-ray contour maps (Phillips and others, 1993), were used as estimates of [U] and [Th]. Values for J and $\mathrm{z}$ in the study area are not known, so ranges of values were used based on data from the literature. Three values of J were assumed: 0 (no helium flux), $3 \times 10^{-6}$ (average crustal degassing rate; O’Nions and Oxburgh, 1983), and $3 \times 10^{-5}$ (a high degassing rate, such as was reported in a tectonically active area of California; Kulongoski and others, 2005) cubic centimeters of helium-4 at standard temperature and pressure, per square centimeter, per year $\left(\mathrm{cm}^{3} \mathrm{STP}{ }^{4} \mathrm{He} / \mathrm{cm}^{2} \cdot \mathrm{yr}\right.$,). Two values of $\mathrm{z}$ were assumed (670 and 1,200 meters) based on data for the Wasatch Formation reported by URS Corporation (2006).

Apparent helium-4 ages were calculated for water from grflds 9 because it had the highest measured helium- 4 concentrations and tritium data indicate it contained no young groundwater. The oldest calculated ages (more than 5 million years) were obtained for the zero flux condition (table 2), but that condition does not seem likely for water from grflds 9 based on the helium- 4 concentration gradients in figure 17 . The higher-flux conditions resulted in ages from about 19,000 to 326,000 years (table 2), which were substantially older than the apparent ages for the other samples from the Wasatch Formation (fig. 11) and indicate a deep source for helium-4 in that sample. The co-occurrence of high concentrations of methane with helium-4 in that sample (fig. 16A) implies the biogenic methane also was derived from a deep source. Although the values of $\mathrm{J}$ selected for this analysis were intended to represent a range of possible flux conditions it is not possible to directly evaluate their applicability to the study area in the absence of other data such as groundwater radiocarbon ages (Kulongoski and others, 2005). Also, this age analysis did not account for the effects of diffusion and advective groundwater flow in the aquifer on the observed helium-4 distributions (Stute and others, 1992; Castro and others, 2000). Nevertheless, the apparent helium-4 ages and concentration gradients are generally consistent with the waterisotopic, major-ion, and chloride/bromide data and, together, the diverse geochemical data sets indicate that water, ions, and gases in grflds 9 were derived from deep sources.

\section{Methane Transport}

The water-isotopic and major-ion data indicate the Mesaverde Group was the source of water and ions in grflds9 (figs. 7 and 9A). But it probably was not the source of biogenic methane in grflds9 because methane from the Mesaverde Group appeared to be thermogenic in origin (Johnson and Rice, 1990; Papadopulos and Associates, Inc., 2008) (fig. 14B). Deeper zones in the Wasatch Formation were a more likely source for the biogenic methane in grflds9. The Wasatch Formation extends several hundred meters below the depth of grflds9 on the basis of the isopach map of the Wasatch Formation published by URS Corporation (2006). Water from the Mesaverde Group could incorporate biogenic methane from the deep Wasatch Formation before entering the shallow Wasatch Formation if it moved through natural fractures or uncemented annular space in gas wells that intersected zones enriched in biogenic methane. The north-south trending zone where domestic wells produced water with high methane and helium-4 concentrations generally coincided with known geologic structures such as the Divide Creek anticline, RifleGrand Hogback syncline, and deep faults (figs. 6 and 15), and they could be pathways for water and gas migration. This convergence of chemistry and geologic structure was noted by URS Corporation (2006) and Papadopulos and Associates, Inc. (2008). A compilation of data on surface-casing depths in 924 gas wells in the study area done by URS Corporation (2006) showed a median casing depth of $260 \mathrm{~m}$, which is probably several hundred meters above the base of the Wasatch Formation in the high methane zone. Presumably, the annular space in those wells was uncemented between the bottom of the surface casing in the Wasatch Formation and the top of cement used to seal the gas-producing interval in the Mesaverde Group (URS Corporation, 2006). Some of those uncemented intervals could contain high concentrations of biogenic methane and act as pathways for water and gas migration.

Well LANG13WW, in contrast to grflds9, had waterisotopic and major-ion compositions similar to that of water from the shallow Wasatch Formation (figs. 8, 9B, and 12), but it contained thermogenic methane (fig. 14B). Both wells contained more than $1 \mathrm{mg} / \mathrm{L}$ methane. The data from

Table 2. Modeled helium-4 ages, in years, of water from well grflds9, Garfield County, Colorado.

[ppm, parts per million; g/ $\mathrm{cm}^{3}$, grams per cubic centimeter; ${ }^{4} \mathrm{He}_{\text {sol }}$, helium-4 solution rate; $\mathrm{cm}^{3} \mathrm{STP} / \mathrm{g} \cdot \mathrm{yr}$, cubic centimeters at standard temperature and pressure, per gram of water, per year; ${ }^{4} \mathrm{He}_{\text {crustal }}$, concentration of crustal helium-4 in the sample; $\mathrm{cm}^{3} \mathrm{STP} / \mathrm{g}$, cubic centimeters at standard temperature and pressure, per gram of water; J, helium-4 flux across the base of the aquifer; $\mathrm{cm}^{3} \mathrm{STP} / \mathrm{cm}^{2} \cdot \mathrm{yr}$, cubic centimeters at standard temperature and pressure, per square centimeter, per year; $z$, distance from well screen to base of aquifer; $\mathrm{m}$, meters. Fixed parameter values in the models: uranium concentration in sediment $=2.2$ ppm; thorium concentration in sediment $=9.0 \mathrm{ppm}$; porosity $=0.2 ;$ sediment bulk density $\left.=2.6 \mathrm{~g} / \mathrm{cm}^{3} ;{ }^{4} \mathrm{He}_{\text {sol }}=5.42 \times 10^{-12} \mathrm{~cm}{ }^{3} \mathrm{STP} / \mathrm{g} \cdot \mathrm{yr}\right]$

\begin{tabular}{|c|c|c|c|c|c|c|c|c|}
\hline \multirow{2}{*}{$\begin{array}{l}\text { Well } \\
\text { name }\end{array}$} & \multirow{2}{*}{$\begin{array}{l}\text { Sample } \\
\text { date }\end{array}$} & \multirow{2}{*}{$\begin{array}{c}{ }^{4} \mathrm{He}_{\text {crustal }} \\
\left(10^{-8} \mathrm{~cm}^{3} \mathrm{STP} / \mathrm{g}\right)^{1}\end{array}$} & \multicolumn{2}{|c|}{$\begin{array}{c}\mathrm{J}=0 \\
\left(\mathrm{~cm}^{3} \mathrm{STP} / \mathrm{cm}^{2} \cdot \mathrm{yr}\right)\end{array}$} & \multicolumn{2}{|c|}{$\begin{array}{c}J=3 \times 10^{-6} \\
\left(\mathrm{~cm}^{3} \mathrm{STP} / \mathrm{cm}^{2} \cdot \mathrm{yr}\right)\end{array}$} & \multicolumn{2}{|c|}{$\begin{array}{c}\mathrm{J}=3 \times 10^{-5} \\
\left(\mathrm{~cm}^{3} \text { STP } / \mathrm{cm}^{2} \cdot \mathrm{yr}\right)\end{array}$} \\
\hline & & & $\mathrm{z}=670 \mathrm{~m}$ & $\mathrm{z}=1,200 \mathrm{~m}$ & $\mathrm{z}=670 \mathrm{~m}$ & $z=1,200 \mathrm{~m}$ & $z=670 \mathrm{~m}$ & $\mathrm{z}=1,200 \mathrm{~m}$ \\
\hline grflds9 & $10 / 28 / 2009$ & 4,250 & $7,841,328$ years & $7,841,328$ years & 185,346 years & 325,870 years & 18,937 years & 33,853 years \\
\hline
\end{tabular}

${ }^{1}$ Recharge temperature assumed to equal 7.9 degrees Celsius. 
LANG13WW could be consistent with fluids containing a high ratio of gas to water leaking upward from the Mesaverde Group, whereas the data from grflds9 appear to be more consistent with the leaking fluids containing a low ratio of gas to water. Determining whether these apparent differences in ratios of gas to water are indicative of different transport pathways was beyond the scope of this investigation. To address that question it would be helpful to collect more geochemical data that could be used to trace water, ion, and gas movement in the area around those wells. Equally important would be the collection of detailed geospatial data on water-well, gas-well, and fracture locations to determine whether the thermogenic gas in water wells could be spatially related to gas wells or to fractures. More generally, it would be helpful to collect a diverse set of baseline geochemical data in areas prior to natural-gas development.

\section{Summary}

Previous water-quality assessments reported elevated concentrations of nitrate and methane in water from domestic wells screened in shallow zones of the Wasatch Formation, Garfield County, Colorado. In 2009, the U.S. Geological Survey, in cooperation with the Colorado Department of Public Health and Environment, analyzed samples collected from 26 domestic wells for a diverse set of geochemical tracers for the purpose of determining sources and sinks of nitrate and methane in groundwater from the Wasatch Formation. The measured constituents included major ions, nutrients, hydrocarbon molecular and isotopic compositions, redox constituents, water isotopic compositions, tracers of groundwater age (tritium, chlorofluorocarbons, sulfur hexafluoride, and tritium/ helium-3), and noble gases. Nitrate concentrations ranged from less than 0.04 to 6.74 milligrams per liter as nitrogen and were highest in young (less than 50 years), oxic (concentrations of dissolved oxygen greater than or equal to 0.5 milligram per liter) groundwater and lowest in anoxic groundwater, regardless of age. Methane concentrations ranged from less than 0.0005 to 32.5 milligrams per liter. High methane concentrations (greater than 1 milligram per liter) occurred in a north-south trending zone of anoxic groundwater located south of Silt, Colorado.

Chloride/bromide mass ratios and tracers of groundwater age indicate that septic-system effluent or animal waste was a source of nitrate in some young groundwater, although other sources such as fertilizer also may have contributed nitrate to the groundwater. Denitrification removed most of the nitrate in anoxic samples. The nitrate concentration in one such sample at the time it recharged the aquifer was calculated to be about 14 milligrams per liter as nitrogen, which would have exceeded the federal drinking-water standard for nitrate, but denitrification in anoxic parts of the aquifer removed 99 percent of the nitrate before it reached the sampled well.
Hydrocarbon molecular and isotopic composition data indicate that the highest concentrations of methane were biogenic in origin. The primary methane sink in the aquifer appeared to be methane oxidation on the basis of dissolvedoxygen and methane concentrations and methane stableisotopic data. The north-south trending zone containing high methane concentrations also was characterized by high concentrations of helium- 4 derived from a relatively deep crustal source on the basis of helium-3/helium- 4 ratios, helium-4 concentration gradients in the aquifer, and apparent helium- 4 groundwater ages (possibly greater than 19,000 years in the sample with the highest helium-4 and methane concentrations). The co-occurrence of high concentrations of methane and helium-4 implies the biogenic methane also was derived from a deep source. One sample containing high concentrations of biogenic methane and helium- 4 had water-isotopic and major-ion compositions similar to that of water from the underlying Mesaverde Group, which was the primary natural-gas producing interval in the study area. Methane from the Mesaverde Group was largely thermogenic in origin so biogenic methane in the sample was more likely derived from deeper zones in the Wasatch Formation.

Water from the Mesaverde Group could incorporate biogenic methane from the deep Wasatch Formation before entering the shallow Wasatch Formation if it moved through natural fractures or uncemented annular space in gas wells that intersected zones enriched in biogenic methane. The north-south trending zone where domestic wells produced water with high methane and helium- 4 concentrations generally coincided with known geologic structures such as the Divide Creek anticline, Rifle-Grand Hogback syncline, and deep faults, and they could be pathways for water and gas migration. A compilation of data on surface-casing depths in 924 gas wells done by URS Corporation (2006) showed a median casing depth of $260 \mathrm{~m}$, which is probably several hundred meters above the base of the Wasatch Formation in the high methane zone. Presumably, the annular space in those wells was uncemented between the bottom of the surface casing in the Wasatch Formation and the top of cement used to seal the gas-producing interval in the Mesaverde Group (URS Corporation, 2006). Some of those uncemented intervals could contain high concentrations of biogenic methane and act as pathways for water and gas migration.

\section{Acknowledgments}

The authors wish to thank homeowners in Garfield County for allowing us to sample their wells. Bryant Jurgens and Mark Levorsen provided helpful comments on earlier versions of the manuscript. 


\section{References Cited}

Andrews, J.N., and Lee, D.J., 1979, Inert gases in groundwater from the Bunter Sandstone of England as indicators of age and palaeoclimatic trends: Journal of Hydrology, v. 41, p. 233-252.

Barker, J.F., and Fritz, P., 1981, The occurrence and origin of methane in some groundwater flow systems: Canadian Journal of Earth Sciences, v. 18, p. 1802-1816.

Bernard, B.B., Brooks, J.M., and Sackett, W.M., 1978, Light hydrocarbons in recent Texas continental shelf and slope sediments: Journal of Geophysical Research, v. 83, p. 4053-4061.

Böhlke, J.K., Wanty, R., Tuttle, M., Delin, G., and Landon, M., 2002, Denitrification in the recharge area and discharge area of a transient agricultural nitrate plume in a glacial outwash sand aquifer, Minnesota: Water Resources Research, v. 38, 10.1029/2001WR000663.

Böhlke, J.K., Verstraeten, I.M., and Kraemer,T.F., 2007, Effects of surface-water irrigation on sources, fluxes, and residence times of water, nitrate, and uranium in an alluvial aquifer: Applied Geochemistry, v. 22, p. 152-174.

Busenberg, E., and Plummer, L.N., 2000, Dating young ground water with sulfur hexafluoride-Natural and anthropogenic sources of sulfur hexafluoride: Water Resources Research, v. 36(10), p. 3011-3030.

Castro, M.C., Stute, M., and Schlosser, P., 2000, Comparison of ${ }^{4} \mathrm{He}$ ages and ${ }^{14} \mathrm{C}$ ages in simple aquifer systems - Implications for groundwater flow and chronologies: Applied Geochemistry, v. 15 , p. $1137-1167$.

Chapelle, F.H., McMahon, P.B., Dubrovsky, N.M., Fujii, R.F., Oaksford, E.T., and Vroblesky, D.A., 1995, Deducing the distribution of terminal electron-accepting processes in hydrologically diverse groundwater systems: Water Resources Research, v. 31, p. 359-371.

Childress, C.J., Foreman, W.T., Connor, B.F., and Maloney, T.J., 1999, New reporting procedures based on longterm method detection levels and some considerations for interpretations of water-quality data provided by the U.S. Geological Survey National Water Quality Laboratory: U.S. Geological Survey Open-File Report 99-193, 19 p.

Clarke, W.B., Jenkins, W.J., and Top, Z., 1976, Determination of tritium by mass spectrometric measurements of ${ }^{3} \mathrm{He}$ : International Journal of Applied Radiation and Isotopes, v. 27 , p. 515-522.

Cook, P.G., and Böhlke, J.K., 2000, Determining timescales for groundwater flow and solute transport, in Cook, P.G., and Herczeg, A., eds., Environmental tracers in subsurface hydrology: Boston, Kluwer Academic Publishers, p. 1-30.

Coplen, T.B., 1988, Normalization of oxygen and hydrogen isotope data: Chemical Geology, v.72, p. 293-297.
Craig, H., 1961, Isotopic variations in meteoric waters: Science, v. 133, p. 1702-1703.

Donnell, J.R., 1969, Paleocene and lower Eocene units in the southern part of the Piceance Creek basin, Colorado: U.S. Geological Survey Bulletin 1274-M, 18 p.

Fishman, M.J., Friedman, L.C., 1989, Methods for determination of inorganic substances in water and fluvial sediments: U.S. Geological Survey Techniques of Water-Resources Investigations, book 5, chap. A1, 54 p.

Grossman, E.L., Cifuentes, L.A., Cozzarelli, I.M., 2002, Anaerobic methane oxidation in a landfill-leachate plume: Environmental Science and Technology, v. 36, p. 2436-2442.

Grout, M.A., and Verbeek, E.R., 1992, Fracture history of the Divide Creek and Wolf Creek anticlines and its relation to Laramide basin-margin tectonism, southern Piceance Basin, northwestern Colorado: U.S. Geological Survey Bulletin 1787-Z, 32 p.

Heaton, T.H.E., and Vogel, J.C., 1981, Excess air in groundwater: Journal of Hydrology, v. 50, p. 201-216.

Helsel, D.R., and Hirsch, R.M., 1992, Statistical methods in water resources: New York, Elsevier, 522 p.

Herzberg, O., and Mazor, E., 1979, Hydrological applications of noble gases and temperature measurements in underground water systems, examples from Israel: Journal of Hydrology, v. 41, p. 217-231.

High Plains Regional Climate Center, 2010, Historical climate data for Colorado: accessed May 27, 2010, at http://www.hprcc.unl.edu/data/historical/index.php.

Hoak, T.E., and Klawitter, A.L., 1977, Prediction of fractured reservoir production trends and compartmentalization using an integrated analysis of basement structures in the Piceance Basin, western Colorado, in Hoak, T.E., Klawitter, A.L., and Blomquist, P.K., eds., Fractured reservoirs - Characterization and modeling: Rocky Mountain Association of Geologists Symposium, p. 67-102.

Hunt, A.G., Lambert, R.B., and Fahlquist, Lynne, 2010, Sources of groundwater based on helium analyses in and near the freshwater/saline-water transition zone of the San Antonio segment of the Edwards aquifer, south-central Texas, 2002-03: U.S. Geological Survey Scientific Investigations Report 2010-5030, 15 p.

Johnson, R.C., and Rice, D.D., 1990, Occurrence and geochemistry of natural gases, Piceance Basin, Northwest Colorado: American Association of Petroleum Geologists Bulletin, v. 74, p. 805-829.

Kaufman, S., and Libby, W.F., 1954, The natural distribution of tritium: Physics Review, v. 93, p. 1337-1344. 
Koterba, M.T., Wilde, F.D., and Lapham, W.W., 1995, Groundwater data-collection protocols and procedures for the National Water-Quality Assessment Program - Collection and documentation of water-quality samples and related data: U.S. Geological Survey Open-File Report 95-399, 113 p.

Kulongoski, J.T., Hilton, D.R., and Izbicki, J.A., 2005, Source and movement of helium in the eastern Morongo groundwater basin, The influence of regional tectonics on crustal and mantle helium fluxes: Geochimica et Cosmochimica Acta, v. 69, p. 3857-3872.

Landon, M.K., Clark, B.R., McMahon, P.B., McGuire, V.L., and Turco, M.J., 2008, Hydrogeology, chemical characteristics, and transport processes in the zone of contribution of a public-supply well in York, Nebraska: U.S. Geological Survey Scientific Investigations Report 2008-5050, 149 p.

Lucas, L.L., and Unterweger, M.P., 2000, Comprehensive review and critical evaluation of the half-life of tritium: Journal of Research of the National Institute of Standards and Technology, v. 105, p. 541-549.

Ludin, A., Weppernig, R., Bonisch, G., and Schlosser, P., 1998, Mass spectrometric measurement of helium isotopes and tritium: Palisades, New York, Lamont-Doherty Earth Observatory, Technical Report 98-06.

Małoszewski, Piotr, and Zuber, Andrzej, 1982, Determining the turnover time of groundwater systems with the aid of environmental tracers. 1. Models and their applicability: Journal of Hydrology, v. 57, p. 207-231.

Maloszewski, Piotr, and Zuber, Andrzej, 1996, Lumped parameter models for the interpretation of environmental tracer data, in International Atomic Energy Agency, Manual on mathematical models in isotope hydrology: Vienna, Austria, IAEA-TECDOC-910, p. 9-58.

Mamyrin, B.A., and Tolstikhin, L.N., 1984, Helium isotopes in nature-Developments in geochemistry 3: Amsterdam, Elsevier, $273 \mathrm{p}$.

Manning, A.H., Solomon, D.K., and Thiros, S.A., 2005, ${ }^{3} \mathrm{H} /{ }^{3} \mathrm{He}$ age data in assessing the susceptibility of wells to contamination: Ground Water, v. 43, p. 353-367.

McMahon, P.B., Böhlke, J.K., and Christenson, S.C., 2004, Geochemistry, radiocarbon ages, and paleorecharge conditions along a transect in the Central High Plains Aquifer, southwestern Kansas, USA: Applied Geochemistry, v. 19, p. $1655-1686$.

McMahon, P.B., and Chapelle, F.H., 2008, Redox processes and water quality of selected principal aquifer systems: Ground Water, v. 46, p. 259-271.
McMahon, P.B., Böhlke, J.K., Kauffman, L.J., Kipp, K.L., Landon, M.K., Crandall, C.A., Burow, K.R., and Brown, C.J., 2008, Source and transport controls on the movement of nitrate to public supply wells in selected principal aquifers of the United States: Water Resources Research, v. 44, W04401, doi:10.1029/2007WR006252.

McMahon, P.B., Carney, C.P., Poeter, E.P., and Peterson, S.M., 2010, Use of geochemical, isotopic, and age tracer data to develop models of groundwater flow for the purpose of water management, northern High Plains aquifer, USA: Applied Geochemistry, v. 25, p. 910-922.

Mullaney, J.R., Lorenz, D.L., Arntson, A.D., 2009, Chloride in groundwater and surface water in areas underlain by the glacial aquifer system, northern United States: U.S. Geological Survey Scientific Investigations Report 2009-5086, $41 \mathrm{p}$.

O'Nions, R.K., and Oxburgh, E.R., 1983, Heat and helium in the Earth: Nature, v. 306, p. 429-431.

Ozima, M., and Podosek, F.A., 1983, Noble gas geochemistry: Cambridge, England, Cambridge University Press, 367 p.

Papadopulos \& Associates, Inc., 2007, Piceance Basin Phase IV baseline water quality study, Garfield County, Colorado: Prepared for the Colorado Oil and Gas Conservation Commission, $22 \mathrm{p}$.

Papadopulos \& Associates, Inc., 2008, Phase II hydrogeologic characterization of the Mamm Creek Field area, Garfield County, Colorado: Prepared for the Board of County Commissioners, Garfield County, Colorado, 41 p.

Phillips, J.D., Duval, J.S., and Ambroziak, R.A., 1993, National geophysical data grids; gamma-ray, gravity, magnetic, and topographic data for the conterminous United States: U.S. Geological Survey Digital Data Series 9, accessed September 10, 2010, at ftp://ftpext.usgs.gov/ pub/cr/co/denver/musette/pub/GEOPHYSICAL_DATA/ cdrom_DDS-9/.

Plummer, L.N., and Busenberg, E., 2000, Chlorofluorocarbons-Tools for dating and tracing young groundwater, in Cook, P., and Herczeg, A., eds., Environmental tracers in subsurface hydrology: Boston, Kluwer Academic Publishers, chap. 15, p. 441-478.

Plummer, L.N., Busenberg, Eurybiades, and Cook, P.G., 2006, Principles of chlorofluorocarbon dating, in International Atomic Energy Agency, Use of chlorofluorocarbons in hydrology-A guidebook: Vienna, International Atomic Energy Agency, p. 17-29.

Rupert, M.G., and Plummer, L.N., 2009, Groundwater quality, age, and probability of contamination, Eagle River watershed valley-fill aquifer, north-central Colorado, 20062007: U.S. Geological Survey Scientific Investigations Report 2009-5082, 59 p. 
Schlosser, P., Stute, M., Dorr, H., Sonntag, C., Munnich, K.O., 1988, Tritium $/{ }^{3} \mathrm{He}$ dating of shallow groundwater: Earth Planetary Science Letters, v. 89, p. 353-362.

Schlosser P., Stute, M., Sonntag, C., and Munnich, K.O., 1989, Tritiogenic ${ }^{3} \mathrm{He}$ in shallow ground water: Earth Planetary Science Letters, v. 94, p. 245-256.

Scott, H.P., Hemley, R.J., Mao, H., Herschbach, D.R., Fried, L.E. Howard, W.M., and Basteal, S., 2004, Generation of methane in the Earth's mantle, In-situ high pressure-temperation measurements of carbonate reduction: Proceedings of the National Academy of Sciences, v. 101, p. 14023-14026.

Sherwood Lollar, B., and Ballentine, C.J., 2009, Insights into deep carbon derived from noble gases: Nature Geoscience, v. 2, 543-547.

Shroba, R.R., and Scott, R.B., 1997, Revised preliminary geologic map of the Rifle Quadrangle, Garfield County, Colorado: U.S. Geological Survey Open-File Report 97-852, 1 sheet.

Shroba, R.R., and Scott, R.B., 2001, Geologic map of the Silt Quadrangle, Garfield County, Colorado: U.S. Geological Survey Miscellaneous Field Studies Map 2331.

Smith, R.L., Howes, B.L., and Garabedian, S.P., 1991, In situ measurement of methane oxidation in groundwater by using natural-gradient tracer tests: Applied and Environmental Microbiology, v. 57, p. 1997-2004.

Solomon, D.K., and Cook, P.G., 2000, ${ }^{3} \mathrm{H}$ and ${ }^{3} \mathrm{He}$, in Cook, P.G., and Herczeg, A., eds., Environmental tracers in subsurface hydrology: Boston, Kluwer Academic Publishers, p. 397-424.

Stute, M., Sonntag, C., Deák, J., and Schlosser, P., 1992, Helium in deep circulating groundwater in the Great Hungarian Plain, flow dynamics and crustal and mantle helium fluxes: Geochimica et Cosmochimica Acta, v. 56, p. 2051-2067.

Thatcher, L.L., 1962, The distribution of tritium fallout in precipitation over North America: Bulletin of the International Association of Scientific Hydrology, v. 7, p. 48-58.

Publishing support provided by:

Denver Publishing Service Center, Denver, Colorado

For more information concerning this publication, contact:

Director, USGS Colorado Water Science Center

Box 25046, Mail Stop 415

Denver, CO 80225

(303) 236-4882

Or visit the Colorado Water Science Center Web site at: http://co.water.usgs.gov/

This publication is available online at: http://pubs.usgs.gov/sir/2010/5215/
Thatcher, L.L., Janzer, V.J., and Edwards, K.W., 1977, Methods for determination of radioactive substances in water and fluvial sediments: U.S. Geological Survey Techniques of Water-Resources Investigations, book 5, chap. A-5, 95 p.

Torgersen, T., 1980, Controls on pore-fluid concentration of ${ }^{4} \mathrm{He}$ and ${ }^{222} \mathrm{Rn}$ and the calculation of ${ }^{4} \mathrm{H} /{ }^{222} \mathrm{Rn}$ ages: Journal of Geochemical Exploration, v. 13, p. 57-75.

Torgersen, T., and Clarke, W.B., 1985, Helium accumulation in groundwater, 1 . An evaluation of sources and the continental flux of crustal ${ }^{4} \mathrm{He}$ in the Great Artesian Basin, Australia: Geochimica et Cosmochimica Acta, v. 49, p. 1211-1218.

Tweto, O., 1979, Geologic map of Colorado: Washington, D.C., U.S. Geological Survey map, scale 1:500,000.

URS Corporation, 2006, Phase I hydrogeologic characterization of the Mamm Creek Field area in Garfield County: Prepared for the Board of County Commissioners, Garfield County, Colorado, 86 p.

U.S. Department of Energy, 2011, Rocky Mountain Basins produced water database: accessed February 1, 2011, at http://www.netl.doe.gov/technologies/oil-gas/Software/ database.html.

U.S. Environmental Protection Agency, 2010, National primary drinking water regulations: accessed October 21, 2010, at http://water.epa.gov/drink/contaminants/index.cfm.

U.S. Geological Survey, 2008a, Reston stable isotope laboratory: accessed June 3, 2010, at http://isotopes.usgs.gov/.

U.S. Geological Survey, 2008b, Reston chorofluorocarbon laboratory: accessed June 3, 2010, at http://water.usgs.gov/lab/.

U.S. Geological Survey, 2010a, Produced waters database: accessed June 16, 2010, at http://energy.cr.usgs.gov/prov/ prodwat/.

U.S. Geological Survey, 2010b, USGS Piceance Basin common data repository: accessed June 16, 2010, at http://rmgsc.cr.usgs.gov/cwqdr/Piceance/.

Van Stempvoort, D., Maathuis, H., Jaworski, E., Mayer, B., and Rich, K., 2005, Oxidation of fugitive methane in groundwater linked to bacterial sulfate reduction: Ground Water, v. 43, p. 187-199.

Whiticar, M.J., 1999, Carbon and hydrogen isotope systematic of bacterial formation and oxidation of methane: Chemical Geology, v. 161, p. 291-314.

Zhang, C., Grossman, E.L., and Ammerman, J.W., 1998, Factors influencing methane distribution in Texas groundwater: Ground Water, v. 36, p. 58-66.

Zhou, Z., Ballentine, C.J., Kipfer, R., Schoell, M., and Thibodeaux, S., 2005, Noble gas tracing of groundwater/ coalbed methane interaction in the San Juan Basin, USA: Geochimica et Cosmochimica Acta, v. 69, p. 5413-5428. 


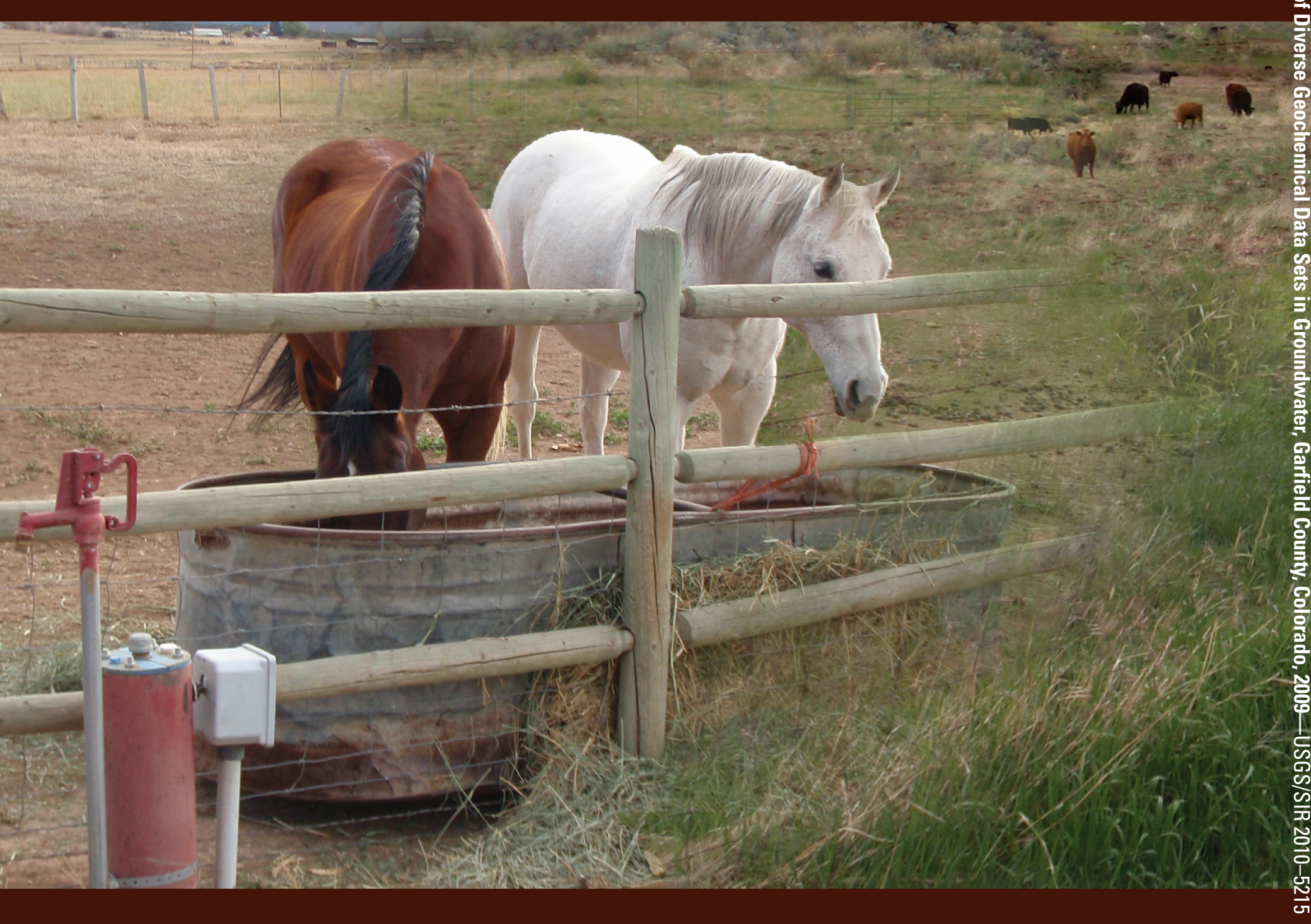

